\title{
ACTINOPTERYGIANS OF THE BROUMOV FORMATION (PERMIAN) IN THE CZECH PART OF THE INTRA-SUDETIC BASIN (THE CZECH REPUBLIC)
}

\author{
STANISLAV ŠTAMBERG \\ Museum of Eastern Bohemia in Hradec Králové, Eliščino nábřeží 465, 500 01 Hradec Králové, the Czech Republic; \\ e-mail: s.stamberg@muzeumhk.cz.
}

Stamberg, S. (2021): Actinopterygians of the Broumov Formation (Permian) in the Czech part of the Intra-Sudetic Basin (the Czech Republic). - Fossil Imprint, 77(1): 73-101, Praha. ISSN 2533-4050 (print), ISSN 2533-4069 (on-line).

\begin{abstract}
Actinopterygians from the Permian sediments of the Czech part of Intra-Sudetic Basin, occurring in the Ruprechtice and Otovice Limestone horizons (Broumov Formation), are revised and redescribed based on both old material and newly discovered specimens. A new diagnosis and reconstruction of Paramblypterus vratislaviensis (AGASSIZ, 1833), the most numerous actinopterygian of the Ruprechtice Limestone Horizon, and the rare Paramblypterus zeidleri (FrITSCH, 1895) are published. First actinopterygians from the Otovice Limestone Horizon were described. Most of the specimens from the Otovice Limestone are referred here to Paramblypterus cf. rohani and Paramblypterus sp. Representatives of Aeduellidae have also recently been discovered in the Otovice Limestone. Osteological fragments belonging to a new taxon exhibit the diagnostic features of the genera Aeduella and Bourbonnela. The reasons for the significantly different faunistic content in the stratigraphically close Ruprechtice Limestone Horizon and Otovice Limestone Horizon are discussed.
\end{abstract}

Key words: Actinopterygii, anatomy, Permian, Intra-Sudetic Basin, Bohemian Massif

Received: January 21, 2021 | Accepted: March 11, 2021 | Issued: December 9, 2021

Zoobank: http://zoobank.org/urn:Isid:zoobank.org:pub:EEA2111C-2B5B-46E4-B267-8CF33DC54AB4

\section{Introduction}

The Intra-Sudetic Basin belongs to the freshwater PermoCarboniferous basins of the Bohemian Massif, and its lower Permian sediments contain vertebrate fauna in which the actinopterygians are the most abundant. Occurrence of actinopterygians and other vertebrate fauna is concentrated in two fossiliferous limestone horizons of the Olivětín Member, the Ruprechtice and Otovice horizons. It was the fauna of the Intra-Sudetic Basin which was one of the first objects of vertebrate research in the Permo-Carboniferous in the Bohemian Massif. The actinopterygian fish Palaeonicus vratislaviensis was the first actinopterygian from the Bohemian Massif described by Agassiz (1833). Another rich vertebrate fauna from the Permian of the Intra-Sudetic Basin was subsequently studied. Several actinopterygian taxa were described by Antonín Frič (Fritsch 1894, 1895), xenacanthids sharks were described by Goldfuss (1847) and Fritsch (1890) and amphibians were introduced by Fritsch (1879, 1880, 1885, 1901). It was Prof. Antonín Frič who should have the greatest credit for knowledge of the Intra-Sudetic Basin fauna. He obtained very rich vertebrate material from the then active small limestone quarries in the area of Ruprechtice and Olivětín villages, and he gradually published the results of his studies in his monumental work "Fauna der Gaskohle und der Kalksteine der Permformation Böhmens". There are only a few references about finds of flora and actinopterygian scales from mapping work (Havlena and Špinar 1956) or lists of fauna and localities (Štamberg 1999, Štamberg and Zajíc 2008) published in the following years. It was amphibians which first attracted the attention of the later revising authors. They were revised by Werneburg (1993) and Werneburg and Steyer (2002). In addition, xenacanthid sharks were revised by Schneider and Zajíc (1994). Only actinopterygian fishes had not been studied since the times of Antonín Frič. A large amount of new material has accumulated during the last 50 years of site research in the Intra-Sudetic Basin. This allows the studies of Antonín Frič to be significantly extended and completely new knowledge be presented on the actinopterygians of the Intra-Sudetic Basin.

\section{Geological context}

The Intra-Sudetic Basin is located on the border of Poland and the Czech Republic and its area extends to about 1,800 $\mathrm{km}^{2}$. Less than a third of the basin is located on the territory of the Czech Republic. Its origin and development is connected 

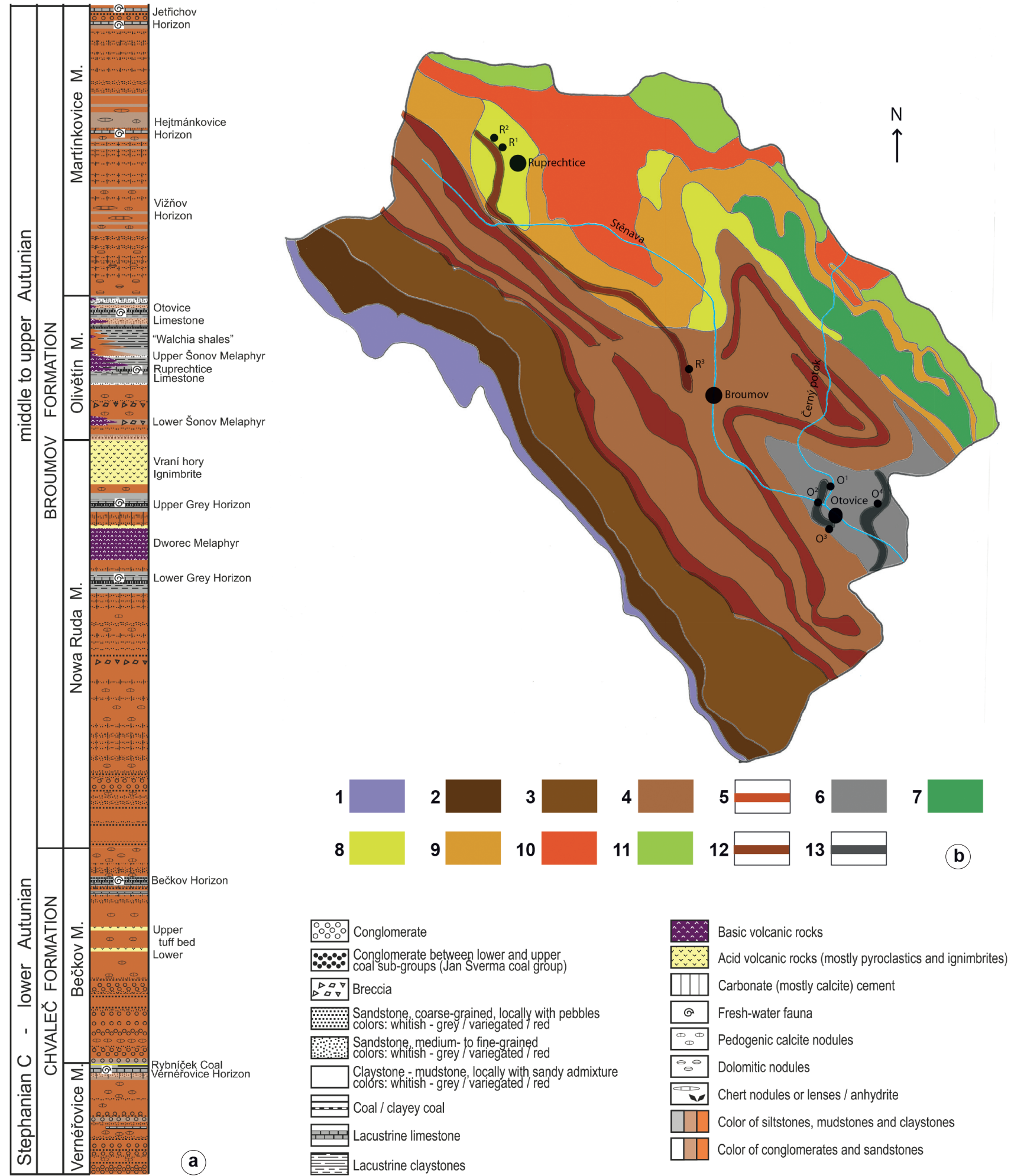

Text-fig. 1. a: Idealised section of the Intra-Sudetic Basin (from Opluštil et al. 2016); b: Geological sketch map of the IntraSudetic Basin, here simplified (after Prouza and Tásler 2001, Pešek 2004). Explanations: 1 - Bohdašín Formation (Triassic), 2 Bohuslavice Formation (Thuringian), 3 - Trutnov Formation (Saxonian), 4-13 Broumov Formation (Autunian): 4 - Martínkovice Member, 5 - Martínkovice Member with Jetřichovice, Hejtmánkovice and Vižňov horizons, 6-13 - Olivětín Member: 6 - Walchia bone coal facies, 7 - Basaltoides of the Šonov Group, 8 - Volcanoclastic facies, 9 - Aleuropelites, 10 - Ignimbrites, 11 - Rhyolite tuffs, 12 - Ruprechtice Limestone Horizon, 13 - Otovice Limestone Horizon. Localities: $\mathrm{O}^{1}$ - Otovice “Černý potok", $\mathrm{O}^{2}$ - Otovice "Stěnava", $\mathbf{O}^{3}$ - Otovice "Chmelnice", $\mathbf{O}^{4}$ - Otovice "Vápenka", $\mathbf{R}^{1}$ - Ruprechtice "Vápencové lomy", R² - Ruprechtice "Pod Světlinou”, $\mathbf{R}^{3}$ - Olivětín "Nad náhonem”.

with individual phases of the Variscan orogenesis. It is an intramontaneous depression in the form of a complicated syncline structure (Tásler et al. 1979, Opluštil et al.
2016). The basin was gradually infilled between the early Carboniferous (Tournasian) to the early Triassic. The filling of the basin is continental with fluvial and lacustrine strata 
next to short-term interconnection of the basin with the sea in the late Viséan. Massive sedimentary input in connection with volcanic lava flows and pyroclastic rocks produced a thick filling of the basin which in the Czech part is up to 3,500 m (Prouza and Tásler 2001). The basin filling is divided into eight formations from which the Broumov Formation is the most important in terms of the focus of this work. The early Permian Broumov Formation (Text-fig. 1a) is 800-1,000 $m$ thick and is divided into the Nowa Ruda Member (at the base), Olivětín Member and Martínkovice Member (Tásler et al. 1979). The Olivětín Member is the most important concerning vertebrate occurrence. The Olivětín Member is a $200 \mathrm{~m}$ thick set of colourful rocks with a high proportion of products related to volcanic activity. The lacustrine Ruprechtice Limestone Horizon with a main layer of light grey or pinkish Ruprechtice Limestone, up to $150 \mathrm{~cm}$ in thickness, is important fossiliferous layer. The Ruprechtice Limestone Horizon is located at the base of the Upper Olivětín Member, and it divides the Olivětín Member into the Lower and Upper Olivětín Member. The Lower Olivětín Member is characterized by volcanodetritic sandstones, conglomerates and breccias, whereas the Upper Olivětín Member is composed of Walchia shales with grey siltstones, claystones, bituminous pelites and limestones (Tásler et al. 1979). Another fossiliferous section, the Otovice Limestone Horizon, outcrops in the upper part of the Walchia shales in the vicinity of Otovice village. The complex of these sediments represents lacustrine or lacustrine-deltaic sedimentation that occurred in the case of the Otovice limestone in a reducing environment (Tásler et al. 1979). The age of the Olivětín Member and thus the age of the Ruprechtice and Otovice horizons can be accurately derived from age determination of the Nowa Ruda Member based on a new radioisotope study of the volcanic rock (Opluštil et al. 2016). The age of the volcanic complex in the upper part of the Nowa Ruda Member was confirmed at $297.11 \pm 0.04 \mathrm{Ma}$ and in combination with the thickness of the layers suggests it is the top of the Broumov Formation around $295 \mathrm{Ma}$, at approximately the Asselian/Sakmarian boundary or slightly above (Opluštil et al. 2016). It follows that the Olivětín Member as well as the Ruprechtice and Otovice horizons belong to the Asselian. Determining the age of the Olivětín Member together with the Ruprechtice Horizon is the aim of ongoing research using of different biostratigraphic methods (Schneider and Werneburg 2012, Schneider et al. 2020). Werneburg and Schneider (2006) assigned the Ruprechtice Horizon to their Melanerpeton pusillum-Melanerpeton gracile Zone, which is interpreted to be of Sakmarian to Artinskian age (Schneider et al. 2020). Zajíc (2004) assigned the Ruprechtice Horizon to the Xenacanthus decheni local biozone.

\section{Localities}

The Ruprechtice Limestone Horizon with the fossiliferous layer of Ruprechtice Limestone, outcrops west of the village of Ruprechtice, and it extends in a north-south direction along the river Stěnava to Olivětín (Text-fig. 1b). The most numerous finds of fauna in the past came from the limestone quarries west of the village of Ruprechtice, west of Olivětín, and many fossils were also found during building of Schroll's weaving mill in Olivětín. Otovice Horizon with gray-black to black limestone was intensively mined in the $19^{\text {th }}$ century near Otovice. In the area of Otovice 7 limestone mining sites are mentioned (Anonymous 1894) in the place known as Vápenka (Lederhose). Mining in Otovice was well known to A. Frič. He recorded (Frič 1912) a profile of Dimter's quarry in the site Vápenka in Otovice. Frič mentioned (Fritsch 1894, Frič 1912) only poorly preserved Amblypterus vratislaviensis (AGAssiz, 1833), unsuitable for study, from the limestone in Otovice, and indeed in the National Museum collections there are only a few very poorly preserved pieces from the former mines in Otovice. In recent years, new material has been collected both in the sites of old quarries and especially in the case of Otovice Limestone, at newly discovered sites.

\section{Overview of localities}

See Text-fig. 1b for geographical position of following localities.

Ruprechtice "Vápencové lomy" $\left(\mathrm{R}^{1}\right)$ - artificial outcrops of Ruprechtice Limestone in the area of former limestone quarries.

Ruprechtice "Pod Světlinou" $\left(\mathrm{R}^{2}\right)$ - artficial outcrop of the Ruprechtice Limestone in the field between the northern part of the villages of Ruprechtice and Vižňov under the hill Světlina.

Olivětín "Nad náhonem" $\left(\mathrm{R}^{3}\right)$ - outcrops of Ruprechtice Limestone on the hill side along the race in the area of former adits westward from Olivětín.

Otovice "Černý potok" $\left(\mathrm{O}^{1}\right)$ - outcrop of Otovice Limestone with overlying Walchia shales on the right and left banks of the stream Černý potok.

Otovice "Stěnava" $\left(\mathrm{O}^{2}\right)$ - outcrop of Otovice Limestone in the Stěnava riverbad near house No. 44 in Otovice.

Otovice "Chmelnice" $\left(\mathrm{O}^{3}\right)$ - layers of Otovice Limestone and Walchia shales outcropping on the slope of the hill Chmelnice along the right bank of the race.

Otovice "Vápenka" $\left(\mathrm{O}^{4}\right)$ - outcrops of Otovice Limestone near the former adit eastward of Otovice.

\section{Material and methods}

The type specimens in the Muséum d'Histoire Naturelle de Neuchâtel, Switzerland (MHNN), plus a large collection of more than 600 specimens which were gathered previously by Fritsch which is deposited in the National Museum, Prague (NM-M) were the basis for study of actinopterygians of the Ruprechtice limestone. The collection of actinopterygians suitable for study was complemented by new finds (120 specimens) stored in the Museum of Eastern Bohemia in Hradec Králové (P, G) and the National Museum, Prague (NM-M).

Only the material obtained in the last 50 years, which is contained in three collections, were used for the study of actinopterygians from Otovice limestone. A collection of 110 specimens collected by the author of this paper is stored in the Museum of Eastern Bohemian in Hradec Králové (P, G), 100 specimens from private collector Jiří Holub are now stored in the National Museum, Prague (NM-M), 


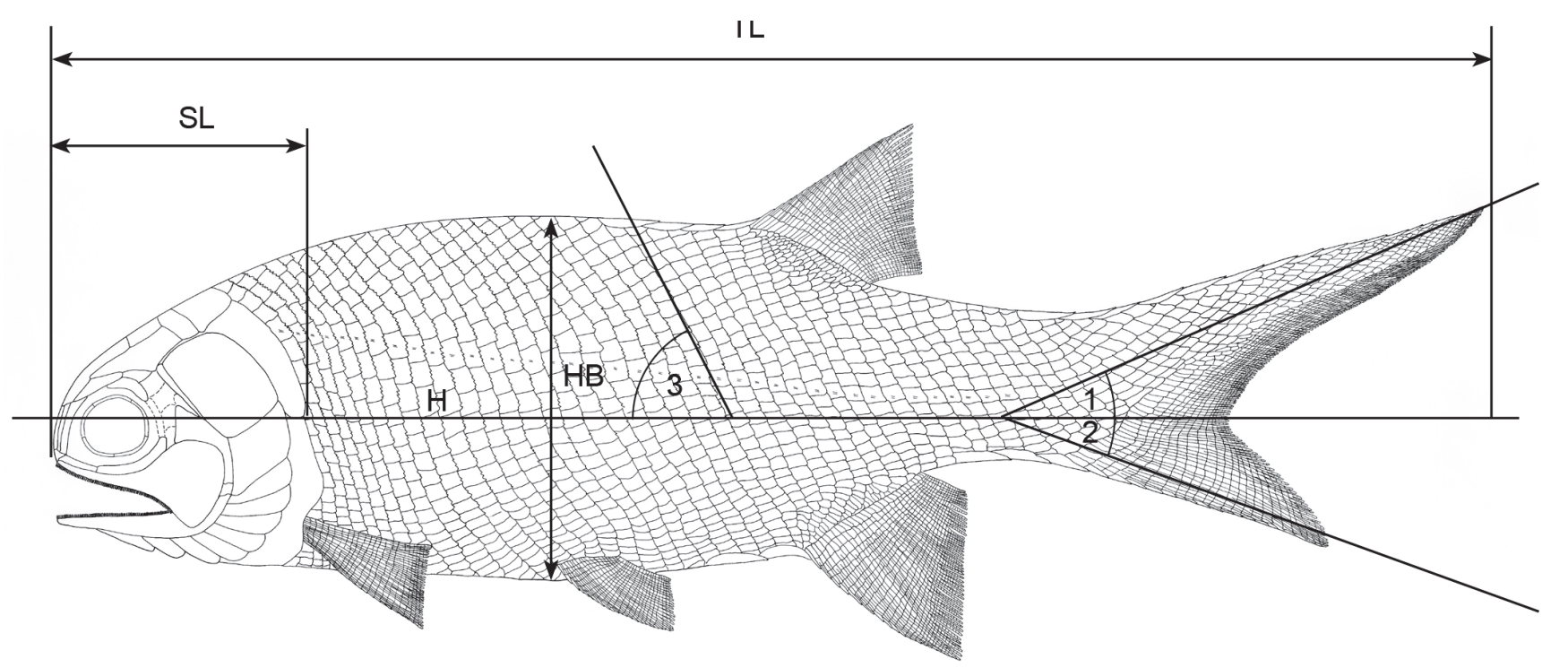

Text-fig. 2. The methods of measurements. $\mathrm{H}$ - horizontal plane, HB - body height, SL - skull length, TL - total body length, 1 - the angle which the dorsal lobe of the caudal fin forms with the horizontal plane, 2 - the angle which the ventral lobe of the caudal fin forms with the horizontal plane, 3 - the angle which the scale row in front of the anal fin forms with the horizontal plane.

and 10 excellent specimens from private collector Martin Souček are now deposited in the collections of the Institute of Geology and Palaeontology, Faculty of Science, Charles University, Prague (DP).

A Krantz pneumatic needle was used for extracting the fossils from the rock, and excess rock was successfully abraded with a toothbrush and a mixture of abrasive material contained in dishwasher powder. Photographs were prepared using a Canon EOS 400D camera, and some of the samples were whitened with ammonium chloride or immersed in ethyl alcohol for both photographing and drawing. The descriptive terminology used in this paper conforms to that adopted by Grande and Bemis (1998) and methods of body measurements are schematically figured in Text-fig. 2. The terms frontal and parietal are used in the traditional sense rather than skull roof terminology based on homology (parietal and postparietal after Schultze 2008). The scale count results were determined, as far as possible, by counting the number of scales along the lateral sensory line. The number in the numerator refers to the number of scale rows dividing the supracleithrum from the anterior margin at the base of the dorsal fin. The first number in denominator means the number of scale rows between the supracleithrum and the anterior margin of the pelvic fin base; the second one is the number of scale rows between the supracleithrum and the anal fin base; the third one is the number of scale rows between the supracleithrum and the caudal fin base. The final number represents the total number of scale rows from the supracleithrum to the point of which the dorsal lobe of the caudal fin ascends (i.e., where the scales change their direction).

During the $19^{\text {th }}$ century the general description of actinopterygians and also the determination of species from the Intra-Sudetic Basin were usually based on the location of fins and their mutual position on the body. The quantity of Paramblypterus vrastislaviensis (AGAssiz, 1833) specimens from the Ruprechtice limestone produced these data for a large number of individuals. The results of Weiss (1864) measurements of specimens from the Ruprechtice limestone led this author to distinguish several subspecies. However, these subspecies are not a reflection of taxonomic diversity, but a record of different types of deformation of individuals. It was detected during the present study that even slightly deformed specimens provide diametrically different data on the position of the fins, and thus they cannot be used for taxonomy purposes. Therefore, only a few specimens which were undeformed could be used to determine the body proportions and position of the fins.

\section{Institutional abbreviations}

DP Institute of Geology and Palaeontology, Faculty of Science, Charles University, Prague, the Czech Republic

NM-M Department of Palaeontology, National Museum, Prague, the Czech Republic

MHNN Muséum d'Histoire Naturelle de Neuchâtel, Neuchâtel, Switzerland

P, G Museum of Eastern Bohemia in Hradec Králové, Hradec Králové, the Czech Republic

\section{Systematic palaeontology}

\section{Family Amblypteridae Romer, 1945 \\ Genus Paramblypterus SAuvage, 1888}

Remarks. The family Amblypteridae with the type genus Amblypterus and the genus Paramblypterus have been the subject of further study in recent years and their diagnosis have been emended (Dietze 1999, 2000, Schindler 2007, Štamberg 2013).

\section{Paramblypterus vratislaviensis (Agassiz, 1833)} Text-figs 3-7

1833 Palaeoniscus vratislaviensis Agass.; Agassiz, pp. 60-63, pl. 10, figs 1, 2, 4-6.

1848 Palaeoniscus vratislaviensis Ag.; Giebel, pp. 247-248.

1861 Palaeoniscus Vratislaviensis Agassiz; Geinitz, pp. 18-19. 
"Palaeoniscus" vratislaviensis; Woodward, p. 441. Amblypterus Vratislavensis, (AG).; Fritsch, pp. 100-104, figs 294-296, 310, pls 121-122.

Amblypterus Kablikae, GeIN. sp.; Fritsch, pp. 94-96, fig. 288, pl. 118, figs 1-6; only specimen NM-M 847 from Ruprechtice.

Amblypterus angustus (AG.); Fritsch, p. 114, pl. 126, figs 1-4; non Palaeoniscus angustus (AgAssiz, 1833).

Aeduella vratislaviensis; Heyler, p. 187.

Amblypterus vratislaviensis (AGAssIz, 1833-43); Štamberg, pp. 7, 9, 11, 12 .

“Amblypterus" kablikae (GEINITZ, 1860); Štamberg, pp. 7, 11. Amblypterus vratislaviensis (AgAssiz 1833-43); Štamberg, p. 225.

"Amblypterus" vratislaviensis (AGAssiz, 1833-43); Štamberg and Zajíc, p. 155, fig. 232.

"Amblypterus" kablikae (GeINITz, 1860); Štamberg and Zajíc, fig. 233; only specimen NM-M 847 from Ruprechtice.

Le c t oty pe. Designated here. Specimen MHNN Fos 187 figured by Agassiz (1833: pl. 10, fig. 1). I designated this specimen as lectotype (Text-fig. 3a) because it is figured by Agassiz the first, and it is better preserved than the second specimen MHNN - Fos 188 figured by Agassiz (1833: pl. 10, fig. 2).

Type locality. Ruprechtice, Intra-Sudetic Basin, the Czech Republic.

Stratigraphic horizon and age of the ty p e l o c a lity. Ruprechtice Limestone Horizon, Olivětín Member, Broumov Formation, Asselian, lower Permian.

O c c urre n c e . Ruprechtice, Olivětín, Otovice (Olivětín Member, Intra-Sudetic Basin).

Remarks. Agassiz (1833) described the species Palaeoniscus vratislaviensis on the basis of material which he received from Wroclaw through M. de Dechen and specimens from the collection of Prof. Otto from Wroclaw. Their site was however Ruprechtice near Broumov in the Intra-Sudetic Basin (the Czech Republic). Agassiz (1833: pl. 10, figs 1, 2) figured two specimens (MHNN - Fos187, MHNN Fos188) deposited now in the Muséum d'Histoire Naturelle de Neuchâtel, Switzerland. Both specimens demonstrate the shape of the body, position of the fins and squamation but the bones of the skull are fragmentary and obscure.

Stout body with the small head which comprises approximately $1 / 5$ of the total body length; the pelvic fin not in the middle of the abdomen but closer to the anal fin than to the pectoral; the dorsal fin considerably further to the rear than the middle of the back, and located in the gap between the pelvic and anal fins, and their posterior margin stretches over the anterior margin of the anal fin; the scales are smooth arranged in oblique rows are for Agassiz (1833) the most important characters of Palaeoniscus vratislaviensis.

Weiss (1864) made a measurement at Palaeoniscus vratislaviensis from Ruprechtice, and tried to compare them with some actinopterygians from the Saar-Nahe Basin, Germany. He showed the great variation in the proportions of $P$. vratislaviensis, and on the basis of the measurements he erected several subspecies. The specimens which he used for the study were not specified in any detail and therefore they are not included in the synonymy. Traquair (1877) revised the species ranged to the genus Palaeoniscus. He separated the species with an arched body anteriorly from the dorsal fin and put them into the genus Amblypterus. The main representative of this group is Palaeoniscus duvernoyi (Agassiz, 1833) and P. vratislaviensis is also ranged to this group in addition to several others. Woodward (1891) considered Palaeoniscus vratislaviensis to be a synonym of Amblypterus duvernoyi (Agassiz, 1833).

A revision of Amblypteru vratislavensis was published by Fritsch (1894). He had about 600 specimens for study from the localities Ruprechtice and Olivětín in the Intra-Sudetic Basin. He figured at least partial knowledge of the skull structure (Fritsch 1894: pls 121, 122) although he did state that although a large number of specimens were available, skull construction had not been well preserved. Fritsch (1894: pl. 118) described and figured specimen NM-M 1847 from limestone in Ruprechtice as Amblypterus kablikae (GeINITZ, 1860) and a specimen NM-M 897 of Amblypterus angustus (Agassiz, 1833) which was described and figured by Fritsch (1895: 114, pl. 126, figs 1-4). Both specimens are ranged here to the synonymy of Paramblypterus vratislaviensis.

D i a g o s is. Small fish usually ranging from 100 to $120 \mathrm{~mm}$, exceptionally to $150 \mathrm{~mm}$. The frontal is 3.5 times longer than wide and 2.5 times longer than the length of the parietal. The anterior margin of the frontal is concave medially, interfrontal suture only slightly undulated and without folds, the sculpture on the frontal consists of ridges parallel with the posterior margin of the bone. The dermosphenotic is narrow, elongated anteroposteriorly. The dermopterotic, with lateral process but without posterior process, is narrower anteriorly than posteriorly. The infraorbital superior, dermosphenotic and supraorbital anterior form the dorsal edge of the orbit. The maxilla has a short and high maxillary plate which is convex dorsally, the length/height ratio of the maxillary plate is 1 or less than 1 . The operculum is oblong in shape, 1.4 times deeper than it is long. The scales on the anterior part of the body bear fine ridges extending posteriorly to the denticles. Denticulation decreases on the scales in the posterior direction and the last denticulate scale appears in the $13^{\text {th }}$ scale row. A field of small scales occurs along the base of the anal and dorsal fins.

Comparative description.

Body form. Paramblypterus vratislaviensis is a small fish of fusiform shape with a total body length usually ranging from 100 to $120 \mathrm{~mm}$, exceptionally up to $150 \mathrm{~mm}$ (Text-figs $1,71, \mathrm{~m})$. The body is slightly arched dorsally at a level in front of the pelvic fin. The skull length is 5.5 to 5.9 times the total body length. The body length/depth ratio significantly varies from 3.5 to 5.5 depending upon specimen preservation and the degree of deformation. Based on relatively wellpreserved specimens it can be assumed the total body length is 4 times that of the deepest part of the body. The heterocercal caudal fin is strong. The dorsal fin originates in the middle of the total body length. The anterior begins at the base of the pelvic fin begins directly in the middle between the start of the pectoral and anal fins. The base of the pelvic fin is therefore closer to the anal fin than to the pectoral.

Rostral part (Text-figs 4, 5a, 6b, c). The postrostral with rounded corners is approximately square in shape 

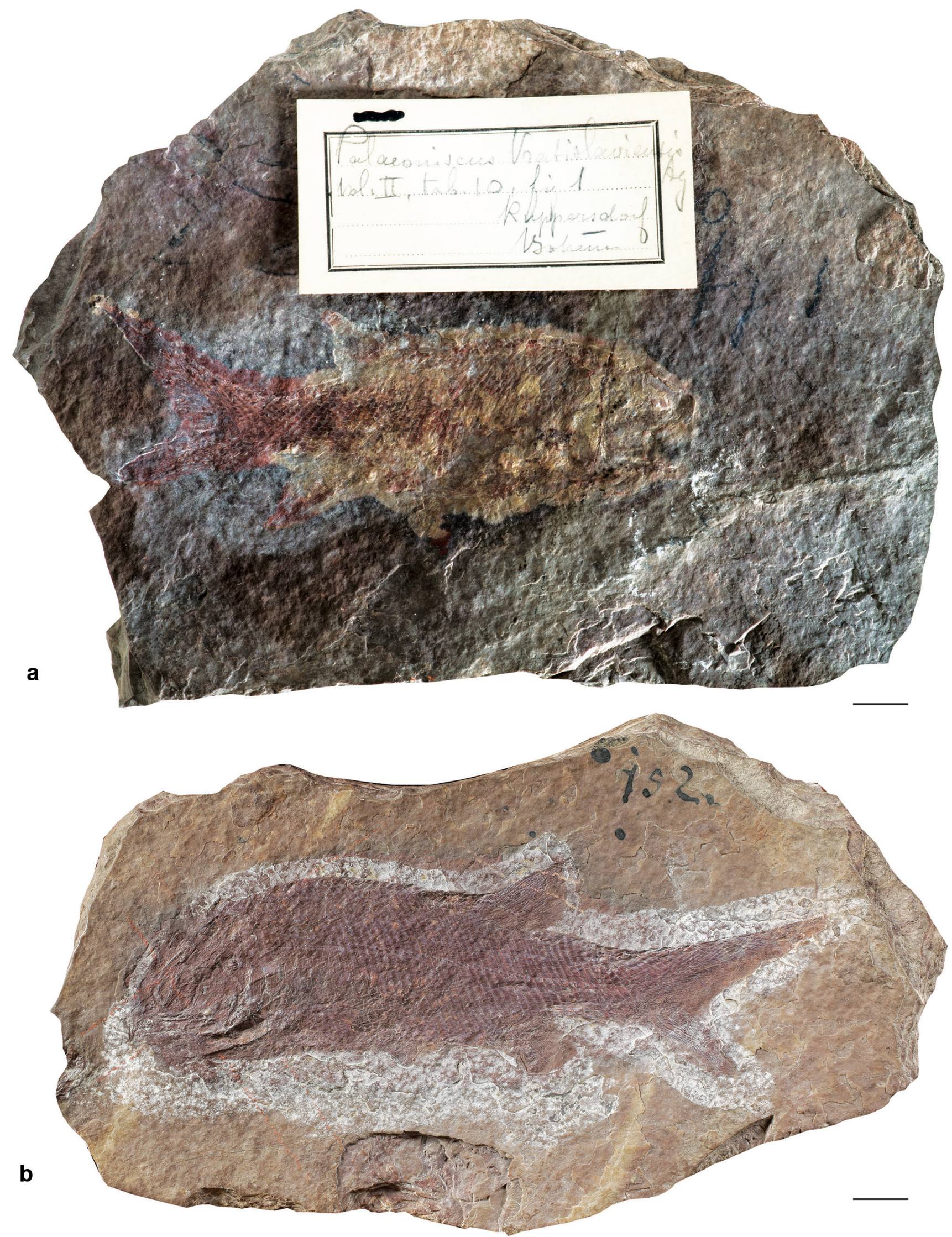

Text-fig. 3. Paramblypterus vratislaviensis (AgAssiz, 1833). Locality Ruprechtice. Scale bars 10 mm. a: lectotype MHNN - Fos 187 figured by Agassiz (1833: pl. 110, fig. 1), photo Alain Germond; b: well preserved body of the specimen NM-M 1095 figured by Fritch (1894: fig. 296, pl. 121, fig. 1).

or slightly elongated in an anteroposterior direction. The postrostral is distinctly convex posteriorly and it fills the space created by the anterior concave margin of the right and left frontals. The narrow nasal (Text-fig. 4c, d) or fused nasal with supraorbital anterior (Text-fig. 4a, b) border the lateral margin of the postrostral. The supraorbital anterior with its 


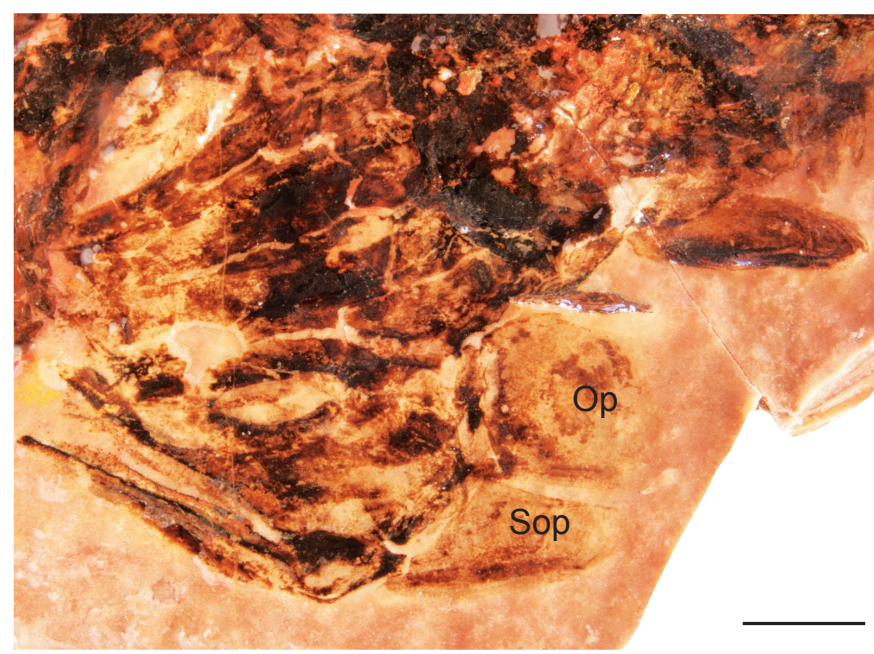

a

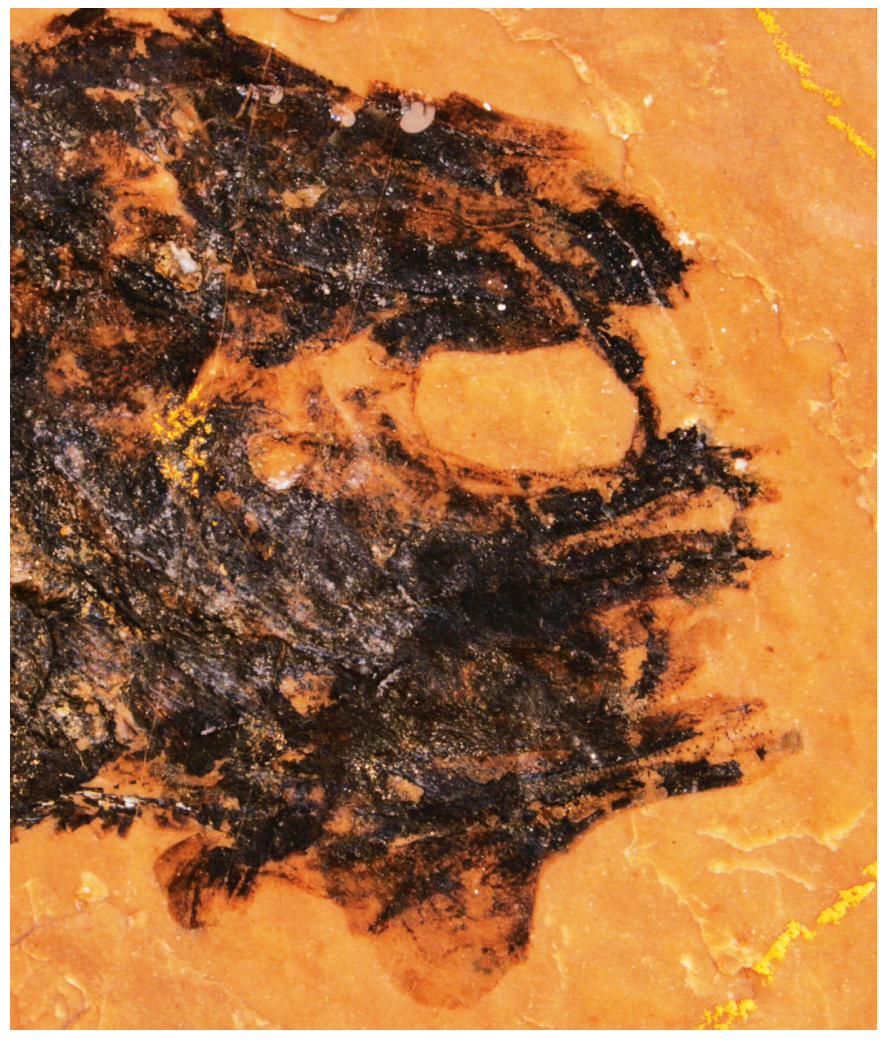

C

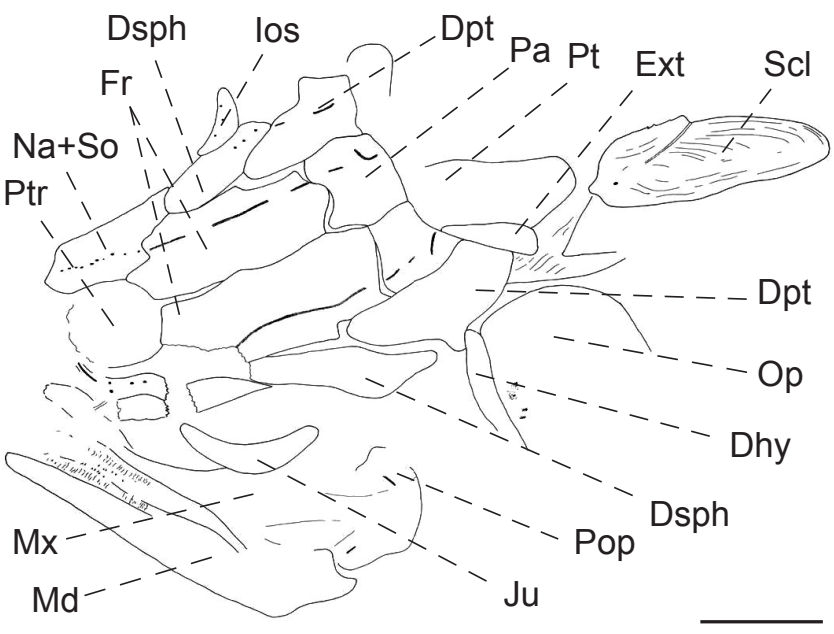

b

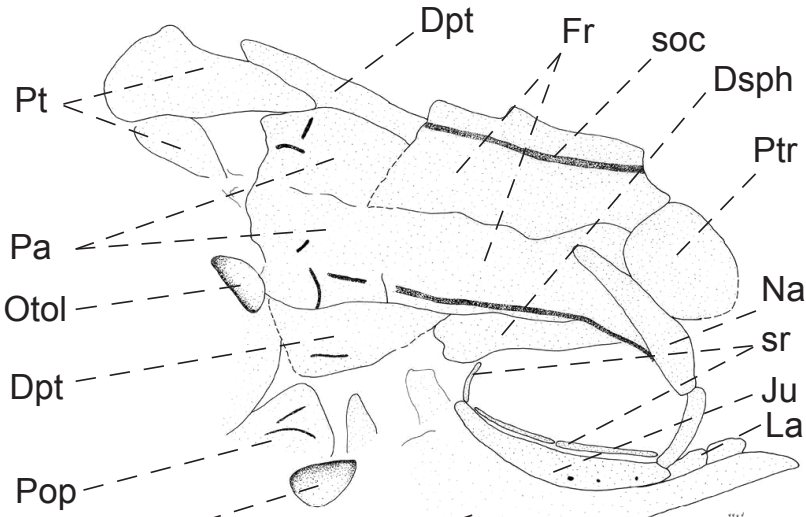

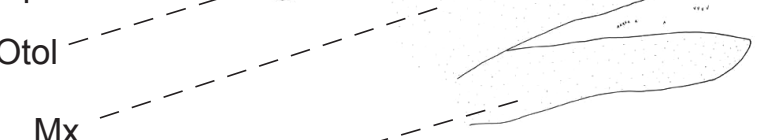

$\mathrm{Mx}$

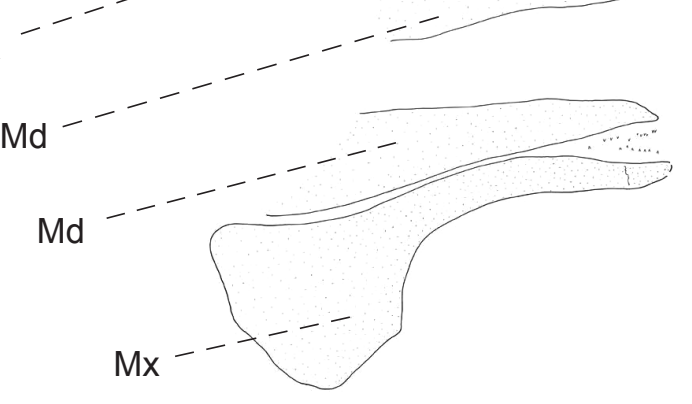

d

Text-fig. 4. Paramblypterus vratislaviensis (Agassiz, 1833). Locality Olivětín. Scale bars 5 mm. a, b: photograph and drawing of the skull. Photograph immersed in ethyl alcohol, NM-M 2461; c, d: photograph and drawing of the skull. Photograph immersed in ethyl alcohol, NM-M 900. Abbreviations: Dhy - dermohyal, Dpt - dermopterotic, Dsph - dermosphenotic, Ext - extrascapular, Fr - frontal, Ios - infraorbital superior, Ju - jugal, La - lacrymal, Md - mandible, Mx - maxilla, Na - nasal, Na+So - nasal coalesces with the supraorbital anterior, Op - operculum, Otol - otolith, Pa - parietal, Pop - preoperculum, Pt - posttemporal, Ptr - postrostral, Scl - supracleithrum, soc - supraorbital canal, sr - sclerotic ring.

concave posteroventral margin forms the anterodorsal edge of the orbit. The supraorbital anterior occurs independently in some specimens (NM-M 2213; Text-fig. 5a) but in others it is fused with the nasal. The supraorbital sensory canal traverses from the frontal to the nasal as a short groove on posterior region of the nasal. Three well preserved pores on the medial margin of the supraorbital anterior indicate the location of the supraorbital sensory canal including the nasal opening. Similar pores on the supraorbital anterior are described (Dietze 1999) in Paramblypterus duvernoyi and are known in aeduellid fish Aeduella blainvillei AgAssiz,
1833 from Bourbon-l'Archambault Basin, France (Štamberg 2018). Anterior termination of the rostral part forms the paired premaxilla. The exact shape and position of this bone is not clearly preserved in any of the individuals, but its fragments on specimens NM-M 2461, P 64714, NM-M 900, P 64726 show its position among the anterior edge of the maxilla, anterior edge of the lacrymal and ventral margin of the postrostral, nasal and supraorbital anterior.

Skull roof (Text-figs 4, 5a, d, 6c). The frontal is long and narrow (NM-M 2213, NM-M 900, NM-M 837, NM-M 2461) and the width of the bone is usually 2.5-3.5 times 


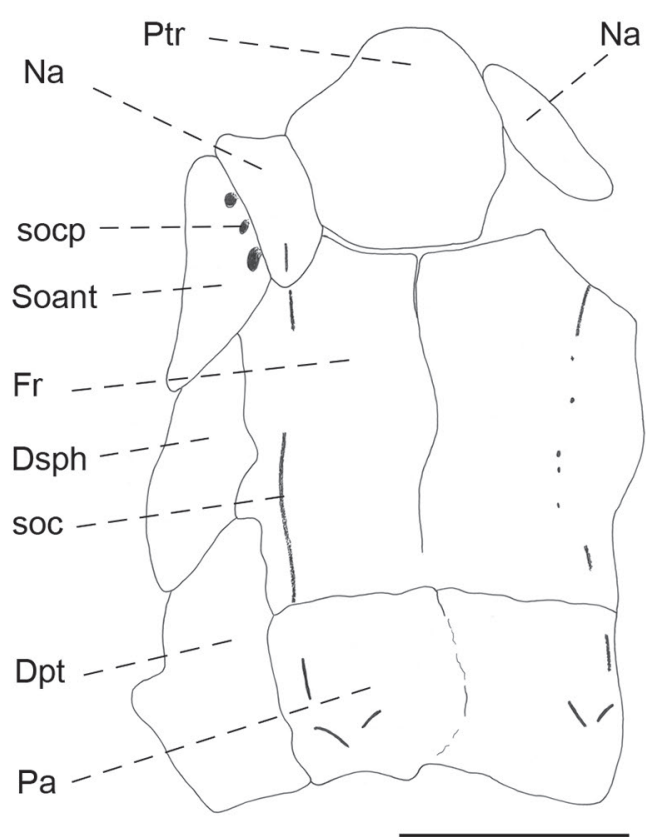

a

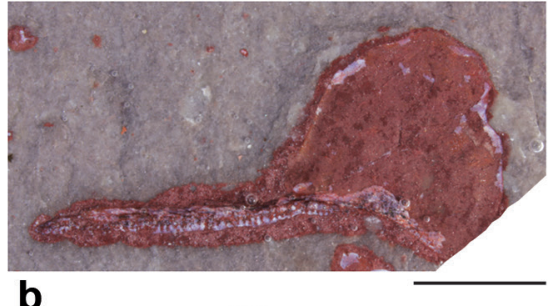

b

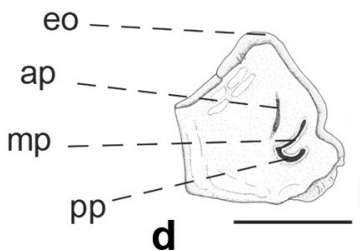

d

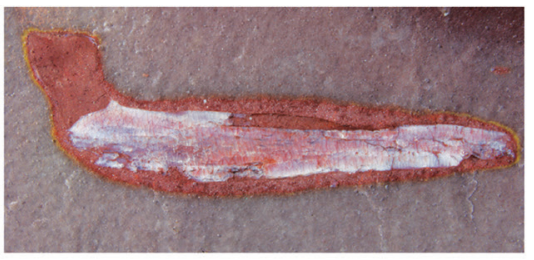

f

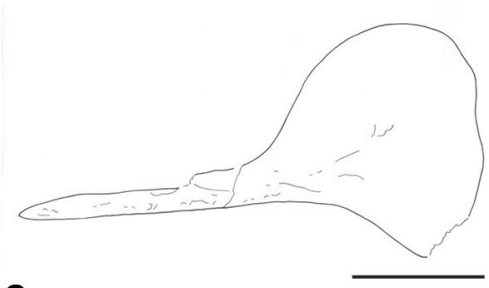

C

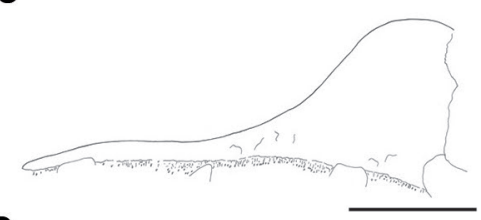

e

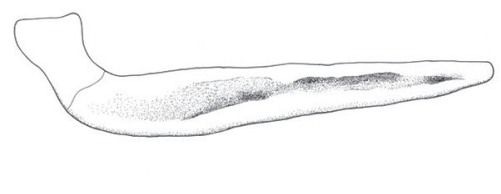

g

Text-fig. 5. Paramblypterus vratislaviensis (Agassiz, 1833). Scale bars $5 \mathrm{~mm}$. a: drawing of the skull roof in dorsal view, locality Olivětín, NM-M 2213; b, c: photograph and drawing of the left maxila in lateral view, locality Ruprechtice, NM-M 64696; d: right parietal in dorsal view, locality Ruprechtice "Pod Světlinou", P 64741; e: left maxilla in lateral view, locality Ruprechtice "Pod Světlinou", P 64738; f, g: photograph and drawing of the left mandible in medial view, locality Ruprechtice "Pod Světlinou", P 64738. Abbreviations: ap - anterior pit line, Dpt - dermopterotic, Dsph - dermosphenotic, eo - edge overlapped by surrounding bones, $\mathrm{Fr}$ - frontal, mp - medial pit line, $\mathrm{Na}$ - nasal, $\mathrm{Pa}$ - parietal, pp - posterior pit line, Ptr - postrostral, soc - supraorbital canal, socp - pores of the supraorbital canal.

its length. Right and left frontals are not the same shape or length. The anterior border of the frontal slopes medially, and the median concave area in front of the frontals is occupied by the postrostral. The anterior edge of the frontal extends on the sides with a forwardly directed protrusion at the boundary between the nasal and postrostral (Text-fig. 4a, b). The anterior edge slopes laterally from the protrusion and it borders with the nasal and supraorbital anterior. The lateral edge of the frontal forms a small process in the posterior third of the length that projects between the dermopterotic and dermosphenotic. The interfrontal suture is without any processes, and it is only slightly wavy. The posterior edge of the frontal has a straight or slightly wavy edge where it is in contact with the parietal. The dorsal surface of the frontal bears well developed ridges and tubercles. On the posterior third of the surface are ridges which are parallel with the posterior margin of the bone. The vermicularly arranged ridges which are common in Paramblypterus rohani are missing. The supraorbital sensory canal is visible in the form of distinctive grooves or pores along the lateral margin of the bone. It traverses in an anterior direction from the anterior margin of the parietal along the lateral margin of the frontal and passes anteriorly to the nasal.

The parietal is square shaped each side being $2-3$ times the length of the frontal. The dermopterotic borders the parietal laterally and the strip of the extrascapulars borders the parietal posteriorly. The dorsal surface of the parietal is sculptured with tubercles and short ridges. The anterior, medial and posterior pit lines are well-developed. The supraorbital sensory canal briefly extends from the frontal to the anterior margin of the parietal (NM-M 900).
The dermosphenotic is a narrow bone in the shape of an anteroposteriorly elongated triangle. It borders laterally the anterior two thirds of the frontal. The posterior edge of the dermosphenotic extends laterally along the anterior and partly lateral borders of the dermopterotic. It anteriorly contacts the supraorbital anterior. The infraorbital superior is attached laterally to the posterior part of the dermosphenotic. Only the infraorbital superior plus the rest of the dermophenotic and supraorbital anterior form the dorsal and anterior rim of the orbit. The markedly anteroposteriorly elongated dermosphenotic differs significantly from the dermosphenotic of Paramblypterus rohani (HeCKel in HeCKel et KNER, 1861) which is shorter and triangular in shape. The pores designate the infraorbital sensory canal which passes from the dermopterotic to the dermosphenotic where it bends laterally and traverses to the infraorbital superior.

The dermopterotic is approximately oblong in shape and borders the posterior third of the frontal and the whole lateral edge of the parietal laterally. The dermopterotic is rounded anteriorly and extends in a posterior direction. A small lateral process is observable in some specimens on the posterior third of the bone. The posterior edge of the dermopterotic is straight without any posterior process as is present in Parambylpteus rohani (HeCKel in HeCKel et KNER, 1861). The strip of extrascapular bones borders the posterior margin of the dermopterotic. The pores and short grooves indicate the course of the infraorbital sensory canal.

The extrascapular bones are poorly preserved on NM-M 1095, NM-M 2461, P 10974, P 30179. The strip of the extrascapular bones probably consists of one pair of 
mediolaterally elongated extrascapular (Text-fig. 4b). Marks of the sensory canal were not observed.

Several Paramblypterus vratislaviensis specimens exhibit otoliths in the form of conspicuous oval shaped humps formed of calcareous material (Text-fig. 4c, d). One otolith occurs on right side and one on the left side of the skull in the place where the parietal is usually preserved (NM-M 837, NM-M 900, P 10954). The oval shape of the otolith is slightly elongated lateromedially while widening laterally. The surface of the otolith is smooth and convex dorsally. The specimen with total body length $100 \mathrm{~mm}$ (NM$M$ 1806) has an otolith of length $2.4 \mathrm{~mm}$ in lateromedial direction and $1.5 \mathrm{~mm}$ in anteroposterior direction. The specimen with total body length $130 \mathrm{~mm}$ (NM-M 1624) has an otolith of proportions $3 \mathrm{~mm}$ and $1.9 \mathrm{~mm}$.

Usually, one pair of otoliths is present in PermoCarboniferous actinopterygians. A pair of larger compact otoliths are mentioned by Schindler (1993) in Meisenheimichthys palatinus (SCHINDLER, 1993) and similar confirms (Schindler 1993) in Aeduella blainvillei (AgAssiz, 1833). Gardiner (1984) mentions one otolith in the saccular chamber of the Devonian Mimipiscis toombsi (GARDINER et BARTRAM, 1977) and similarly Coates (1993) demonstrated one otolith on each side of the skull in the Namurian species Mesopoma carricki CoATEs, 1993 and Mesopoma? smithsoni CoAtes, 1993. Another Namurian Woodichthys bearsdeni Contes, 1998 and Melanecta anneae CoAtes, 1998 also possess one pair of large otoliths. Otoliths from Melanecta anneae have a more or less round shape and one of the specimens exhibits three small otoliths (Coates 1998). Three otoliths, utricular, saccular and lagenal, were also described by Gottfried (1993) in a subadult palaeoniscoid specimen from the Late Pennsylvanian of Kansas. However, it is not entirely clear whether it is a pair of, for example, saccular otoliths.

Only the median parasphenoid is preserved from the bones of the mouth cavity (NM-M 897). The middle part anteroposteriorly forms the elongated corpus parasphenoidis. It projects into the posterior third to one pair of processus ascendens posterior which forms an angle of $60^{\circ}$ with the corpus parasphenoidis. The corpus parasphenoidis is not greatly extended beyond the processus ascendens posterior and it has a semicircular posterior margin. Isolated parasphenoids of the same shape are also preserved in the specimens NM-M 4206, NM-M 4209.

Cheek bones (Text-figs 4, 6a). The large orbit has a sclerotical ring which consists of several rod-shaped bones (NM-M 900; Text-fig. 4c, d). The orbit is surrounded anteriorly and partly dorsally by the supraorbital anterior, dorsally by the dermosphenotic and the infraorbital superior. The lacrymal borders the orbit ventrally and the jugal continues posteriorly. The narrow jugal extends between the anterior border of the maxillary plate and the orbit. The posterior boundary of the orbit is not fully preserved. The jugal and wedge-shaped infraorbital superior participate in the posterior limit of the orbit, but another infraorbital bone which is not preserved on any individual was probably located between them.

The premaxilla ( $\mathrm{P}$ 64714) does not participate in delimiting the orbit anteriorly because it is separated from the orbit by the supraorbital anterior and the lacrymal.
Several pores on the infraorbital superior (NM-M 2461) and jugal (NM-M 900) mark the course of the infraorbital sensory canal. The bones occupying the space posterior to the orbit are not clearly determinable. Several small bones are present but their exact number and location is unclear.

The preoperculum borders the maxillary plate posteriorly and dorsally. The bone broadens conspicuously anteriorly; it narrows posteriorly and the narrow ventroposterior part of the preoperculum is squeezed between the maxillary plate and the suboperculum. The course of the preopercular canal is indicated by short grooves along the posterodorsal edge of the bone, and a short pit line branches off where the bone bends. Along the anterior edge of the operculum is the dorsoventrally elongated narrow dermohyal. It reaches the dermopterotic dorsally, and it narrows ventrally partly separating the operculum from the preoperculum.

Jaws (Text-figs 4, 5b, c, e, f, g, 6a, c, 7h). The maxilla which has a characteristic shape in Paramblypterus vratislaviensis, is preserved in many individuals (e.g., NM-M 900, P 64696, G 127). It has a narrow anterior suborbital part and short high posterior maxillary plate. The maxillary plate forms one third of the length of the maxilla. The maxillary plate is relatively short and high. The length/height ratio of the plate is 1 or less than 1 . The dorsal edge of the plate is convex and the maxillary plate extends ventrally as a small blunt process. The lower jaw is relatively weak, broadens slightly in a posterior direction. There are no sutures on the lower jaw to distinguish the individual bones on the lower jaw, except the coronoids possesses teeth. The lower jaw forms a large dorsal process posteriorly which forms a joint with the quadrate over the articular. Pores from the mandibular sensory canal indicate the course of this canal along the ventral edge of the lower jaw (P 10978, P 64710). Minute sharp pointed teeth connected to short tubules form marginal dentition on the jaws. Small short teeth of conical shape which are firmly connected to the coronoids of the lower jaws complement the dentition on the jaws.

Opercular apparatus (Text-figs 4a, b, 6). An oblong shaped operculum was observed in many specimens. It has a depth to length ratio of 1.4 (P 10974, P 64712, P 64714, $\mathrm{P}$ 64715, NM-M 2461). All corners of the bone are rounded, but it is deformed in some specimens. The depth of the suboperculum with ventroposterior corner is $50 \%$ the length of the operculum. The dorsal margin of the suboperculum is concave while the posterior and ventral margins are convex (P 64710, NM-M 2461). Seven branchiostegal rays follow ventrally from the suboperculum. They are preserved fragmentarily (P 10974, P 64726, P 64716, NM-M 897) and only specimen NM-M 1593 exhibits several but incomplete number of branchiostegal rays. Only fragments of the gular bones are preserved.

Shoulder girdle (Text-figs 4a, b, 6). The oval shaped posttemporal (P 64571, NM-M 1095) attaches to the strip of extrascapular bones in the dorsal part of the skull. The posttemporal anterolaterally forms a conspicuous process wedged between the extrascapular lateral and supracleithrum. The large dorsoventrally elongated supracleithrum continues ventrally from the posttemporal. The supracleithrum articulated with the posttemporal through a large process on the dorsal edge of the supracleithrum. The anterior $1 / 3$ of the surface was covered by the operculum. The supracleithrum 


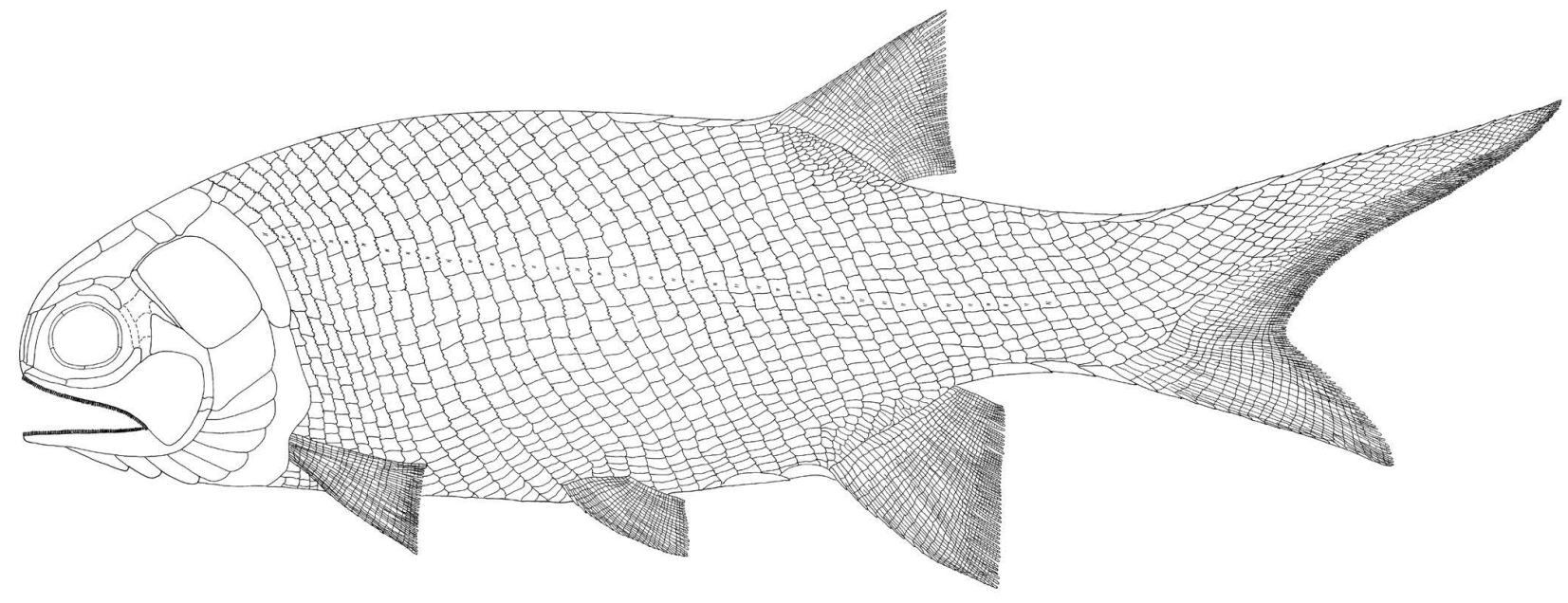

a
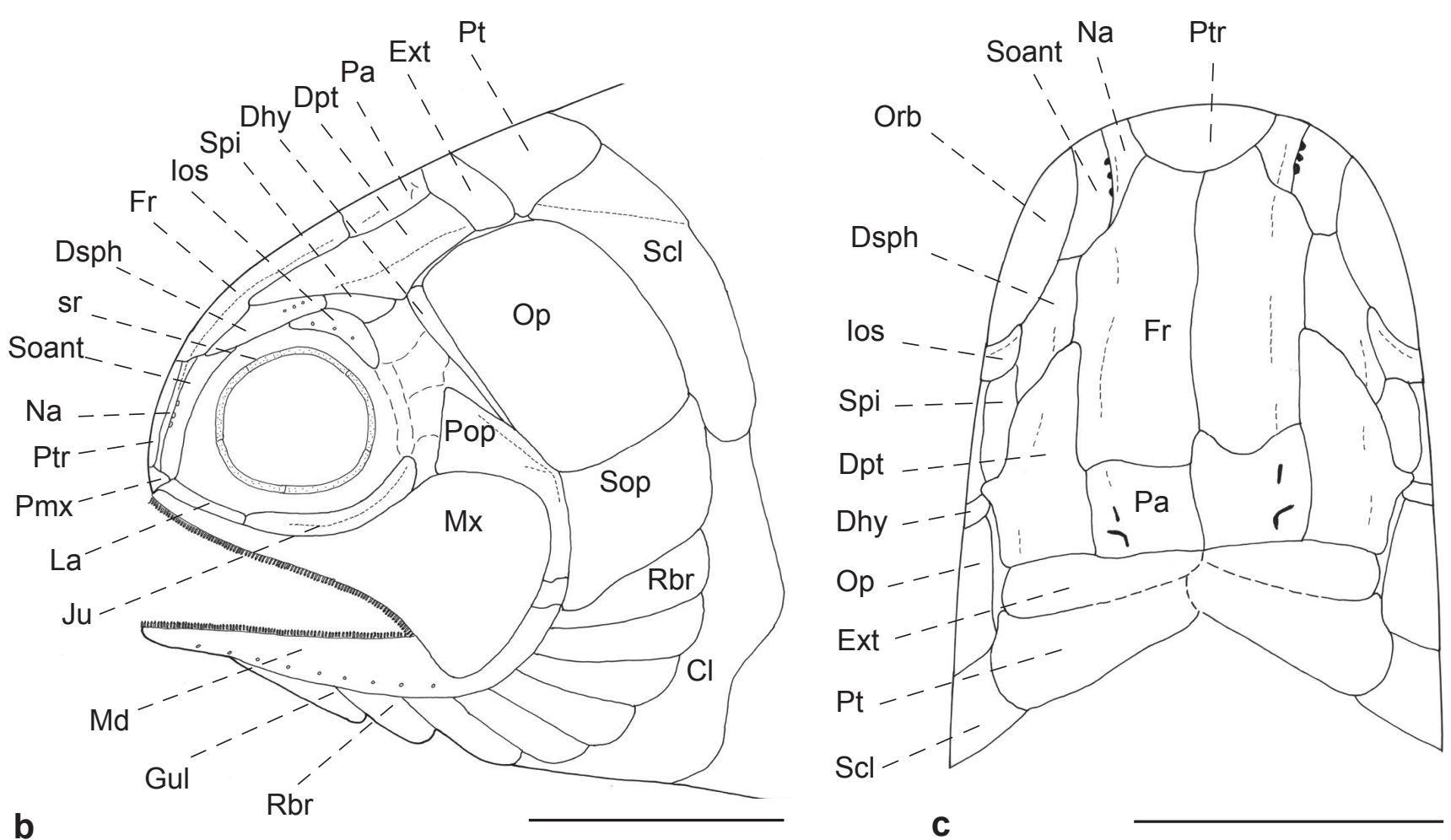

Text-fig. 6. Paramblypterus vratislaviensis (Agassiz, 1833). a: restoration of the body in lateral view, scale bar $10 \mathrm{~mm}$; b: restoration of the skull in lateral view (bones that are not clearly retained on the skull are marked with dashed lines), scale bar $10 \mathrm{~mm}$; c: restoration of the skull in dorsal view, scale bar $10 \mathrm{~mm}$. Abbreviations: Cl - cleithrum, Dhy - dermohyal, Dpt - dermopterotic, Dsph - dermosphenotic, Ext - extrascapular, Fr - frontal, Gul - lateral gular, Ios - infraorbital superior, Ju - jugal, La - lacrymal, Md - mandible, Mx - maxilla, Na - nasal, Op - operculum, Orb - orbit, Pa - parietal, Pmx - premaxilla, Pop - preoperculum, Pt posttemporal, Ptr - postrostral, Rbr- branchiostegal rays, Scl - supracleithrum, Soant - supraorbital anterior, Sop - suboperculum, Spi - spiracular, sr - sclerotic ring.

Text-fig. 7. Paramblypterus vratislaviensis (AgAssiz, 1833). Locality Ruprechtice, beside (7h). a: caudal peduncle with bifurcation of the dorsal and anal lobes of the caudal fin with ridge scales on the dorsal and ventral edgec of the caudal peduncle, $P$ 10977, scale bar $5 \mathrm{~mm}$; b: anal fin, P 10974, scale bar $5 \mathrm{~mm}$; c: anal fin with a field of minute scales along the anal fin base, NM-M 1603, scale bar $5 \mathrm{~mm}$; d, e: drawing and photograph of four ridge scales in front of the dorsal fin base, P 10977, scale bar $5 \mathrm{~mm}$; f: caudal peduncle with bifurcation of the dorsal and ventral lobes of the caudal fin and ridge scales on the dorsal edge of the caudal peduncle, P 19832, scale bar 5 mm; g: dorsal lobe of the caudal fin, P 19832, scale bar 5 mm; h: maxilla in lateral view, locality Otovice, G 127, scale bar $5 \mathrm{~mm}$; i: the scales from the area between the pectoral and pelvic fins, P 10977, scale bar $2 \mathrm{~mm}$; j: small microtubercles with circular base form the microsculpture on the outer surface of the ridge scales in front of the dorsal fin, P 10977, scale bar $50 \mu \mathrm{m}$; k: the scales from 22-24 rows of the lateral side of the body, P 10977, scale bar 2 mm; l: whole specimen, NM-M 1095, scale bar $10 \mathrm{~mm}$; m: whole specimen, P 10974, scale bar $10 \mathrm{~mm}$. 

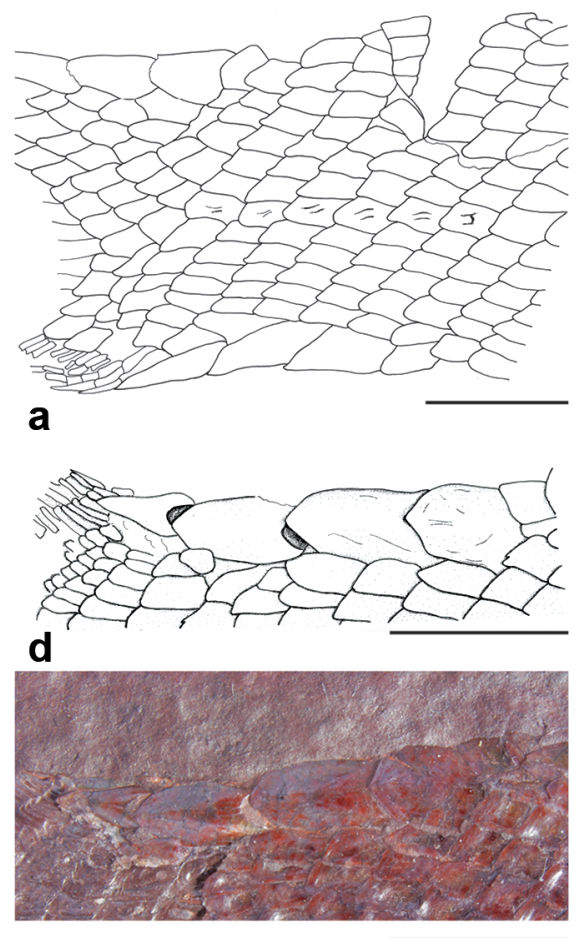

e

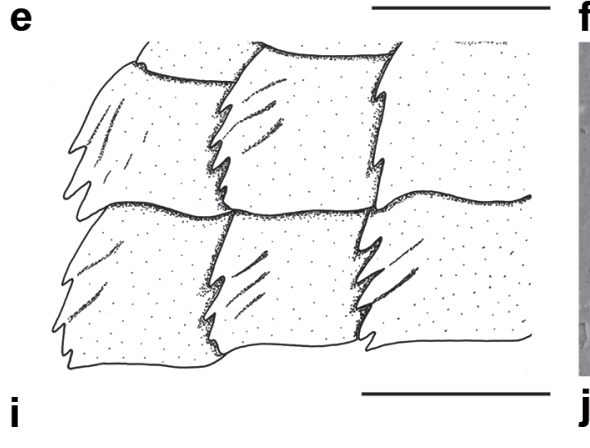

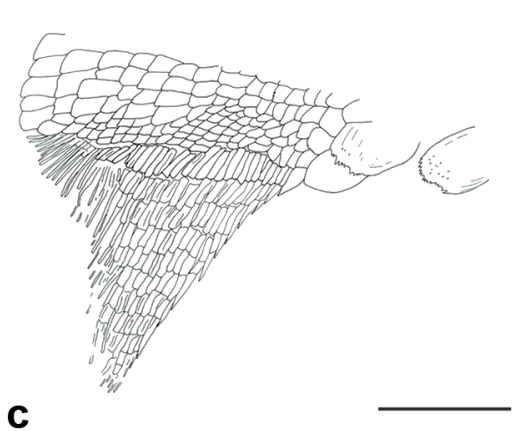

b
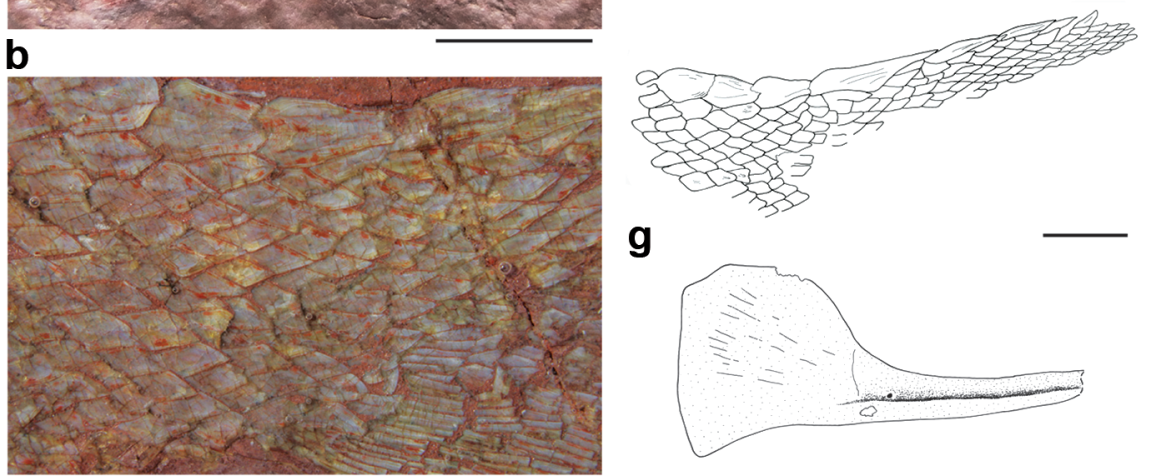

g

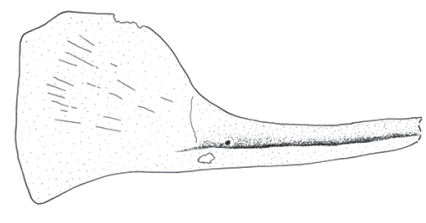

h
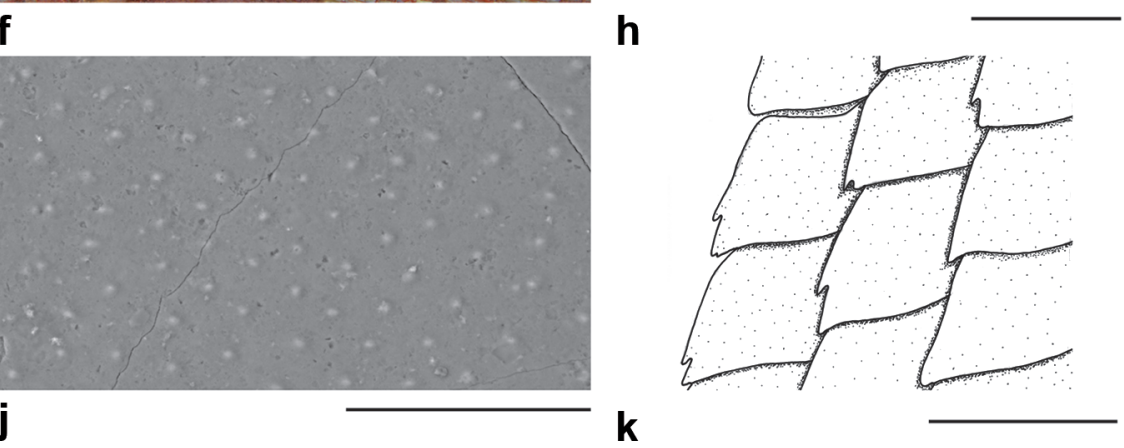
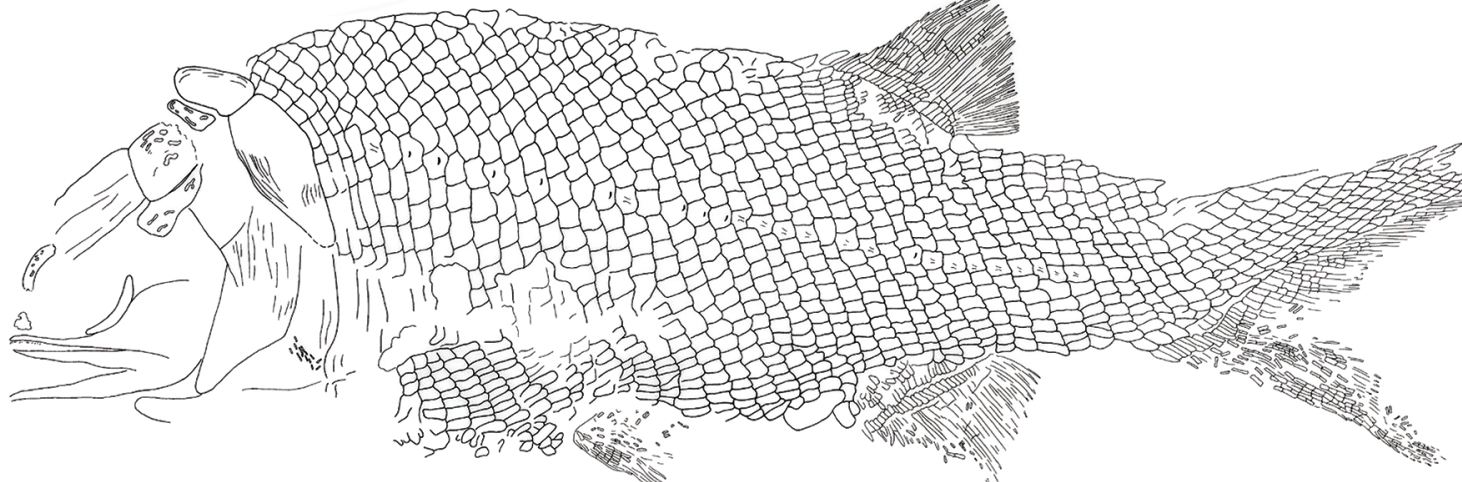

I

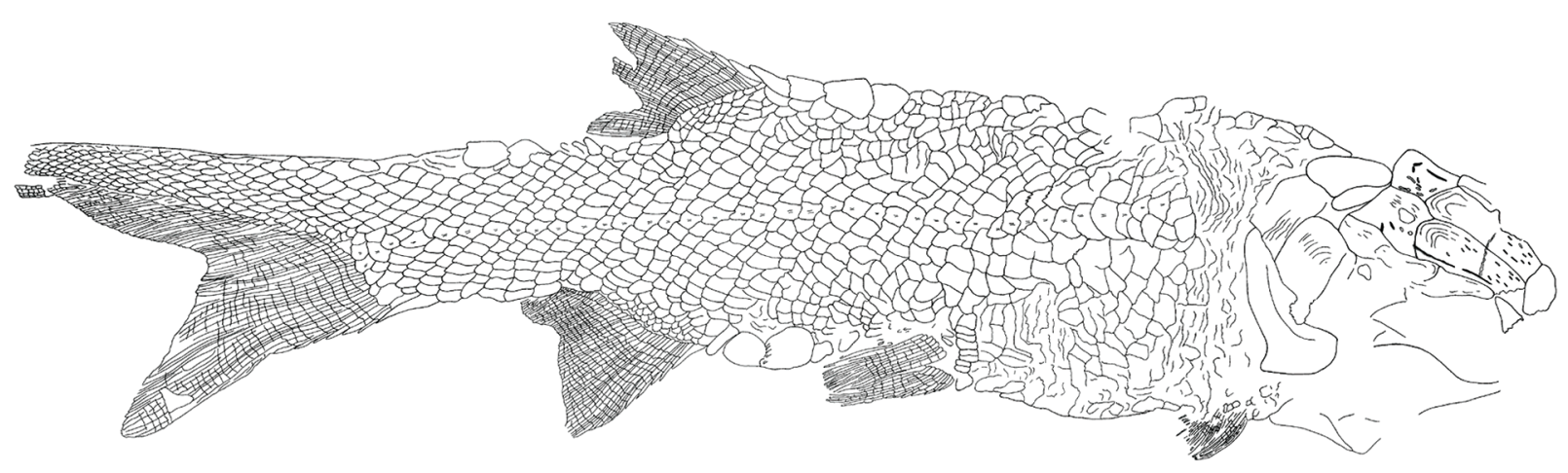

m 
has a rounded ventral margin which extends up to the suboperculum. A lateral sensory line diagonally crosses the dorsal third of the supracleithrum and traverses the lateral side body scales. The cleithrum situated ventrally from the supracleithum is covered by the supracleithrum dorsally and by the suboperculum and branchiostegal rays anteriorly.

Paired fins. The small pectoral fin consists of lepidotrichia which are segmented from their base. The anterior border of the pectoral fin is protected by the terminal pointed segments of the lepidotrichia. The pelvic fin is small and consists of 20 segmented lepidotrichia. The anterior border is protected by the terminal pointed segments of the lepidotrichia. The terminal segments of the first five lepidotrichia form the anterior border of the fin. The sixth lepidotrichium, which consists of 16-18 segments, extends to the distal end of the pelvic fin. The beginning of the fin is beyond the ninth row of the trunk scales. The position of the pelvic fin base on the trunk was monitored in a large number of individuals and its position relative to other fins varied considerably depending on the degree of deformation of the body. In several well-preserved individuals it could be recognised that the beginning of the pelvic fin base is the same distance from the beginning of the pectoral fin and from the beginning of the anal fin base (P 10977, P 30179).

Unpaired fins. The dorsal and anal fins are approximately of the same size with the same length of base, and they are significantly larger than the unpaired fins. The dorsal fin base begins behind the $28^{\text {th }}-29^{\text {th }}$ scale row and in the middle of the total body length. The base extends over six scale rows, and a field of minute scales occurs along the fin base. The dorsal fin consists of 30 segmented lepidotrichia.

The base of the anal fin begins behind $22^{\text {nd }}-23^{\text {rd }}$ row of scales, and it extends over a length of 9 scale rows. Along the base of the fin occurs a field of minute scales (Textfig. $7 b, c)$. The anterior half of the anal fin base is at a level under the dorsal fin base and the posterior half of the anal fin base is behind the base of the dorsal fin (P 19846). The anal fin consists of 30 lepidotrichia and only the ninth reaches the distal end of the fin, it consists of 18-20 segments. The pointed segments of the first eight lepidotrichia terminate at the anterior edge of the anal fin.

The caudal fin is significantly heterocercal with a dorsal lobe 1.7 times longer than the length of the ventral lobe. The dorsal lobe forms an angle of $24^{\circ}$ with the horizontal plane, and the ventral lobe forms an angle of $21^{\circ}$ with the horizontal plane. Lepidotrichia in the ventral lobe of the caudal fin have very long basal segments (P 30179).

Squamation (Text-fig. $7 \mathrm{a}-\mathrm{g}, \mathrm{i}-\mathrm{m})$. The scales on the trunk are arranged in diagonal rows. The row in front of the anal fin forms an angle of $62^{\circ}$ with the horizontal plane. The scale count of

$$
\begin{aligned}
& \begin{array}{c}
28-29 \\
\hline 9-10-42
\end{array} \\
& \text { 9-10 22-23 36-39 }
\end{aligned}
$$

was found on several relatively well-preserved individuals (NM-M 901, NM-M 1095, NM-M 1626, P 30179, NM-M 2474, NM-M 2463, P 19832, NM-M 64697, P 10974, NM-M 1097). The scales are of oblong shape on the lateral side of the body. These scales bear fine ridges extending posteriorly to the denticles. Denticulated scales containing usually 5-7 denticles extend between the skull and pelvic fin. Denticulation of the posterior edge of the scales decreases in a posterior direction and the last serrated scales with one or two denticles can be observed in the $13^{\text {th }}$ row (P 10977, P 64704, P 64710). The scales behind the $13^{\text {th }}$ row are smooth and without serration. The scale row in front of the anal fin contains 13-15 scales (P 30179, P 10974) below the lateral sensory line and 10 above the lateral sensory line.

A ganoine surface of the scales bears microsculpture which consists of tubercles with circular base which are arranged at regular distances (Text-fig. $7 \mathrm{j}$ ). The tubercles forming the microsculpture of Paramblypterus vratislaviensis have the same shape and arrangement as those in Paramblypterus rohani, Paramblypterus duvernoyi or Aeduella blainvillei (Štamberg 2018).

Four ridge scutes in front of the dorsal fin are present (P 30179). A large ridge scute and one paired ridge scute precede the anal fin base. Large ridge scutes extend below the length of three scale rows.

The scale row in front of the beginning of the caudal peduncle contains 15-16 scales (P 10974, P 10977, P 19832, $P$ 64711). Three ventral scutes behind the $35^{\text {th }}$ row of scales protect the ventral edge of the caudal peduncle (P 10977, P 30179). The dorsal scutes on the dorsal edge of the caudal peduncle begin after the last row of body scales (P 19832).

\section{Paramblypterus zeidleri (FRITSCH, 1895)}

Text-fig. 8a

1895 Amblypterus Zeidleri, Fr.; Fritsch, p. 113, pl. 125, figs 4-5. 2008 Paramblypterus zeidleri (FrITSCH, 1895); Stamberg and Zajíc, p. 159, fig. 239.

L e c t o ty p e. Designated here. Specimen NM-M 901 described and figured by Fritsch (1895: pl. 125, figs 4-5 and Text-fig. 8a herein).

Type locality. Ruprechtice, Intra-Sudetic Basin, the Czech Republic.

Stratigraphic horizon and age of the ty pe loc a lity. Ruprechtice Limestone Horizon, Olivětín Member, Broumov Formation, Asselian, lower Permian.

O c c u r r e n c e . Ruprechtice, (Olivětín Member, IntraSudetic Basin).

Remarks. Fritsch (1895) designated Amblypterus zeidleri on the basis of specimen NM-M 901 which comes from the limestone of the Ruprechtice Horizon of the IntraSudetic Basin, and this author (Fritsch 1895: 113; housed in the National Museum, Prague) assigned to the same species another very deformed specimen from the Kalná Horizon of the Prosečné Formation (Krkonoše-Piedmont Basin). The following description is based only on the lectotype NM-M 901 as no other specimen from the Ruprechtice and Otovice horizons corresponds to the characters of the lectotype.

Diagnosis. Body fusiform reaches a total length $16 \mathrm{~cm}$. Total body length is 4.1 times that of the deepest part of the body. The dorsal fin begins behind the mid point of the total body length. The scales between the skull and pelvic fin bear fine diagonally arranged ridges terminating in denticulation posteriorly. 


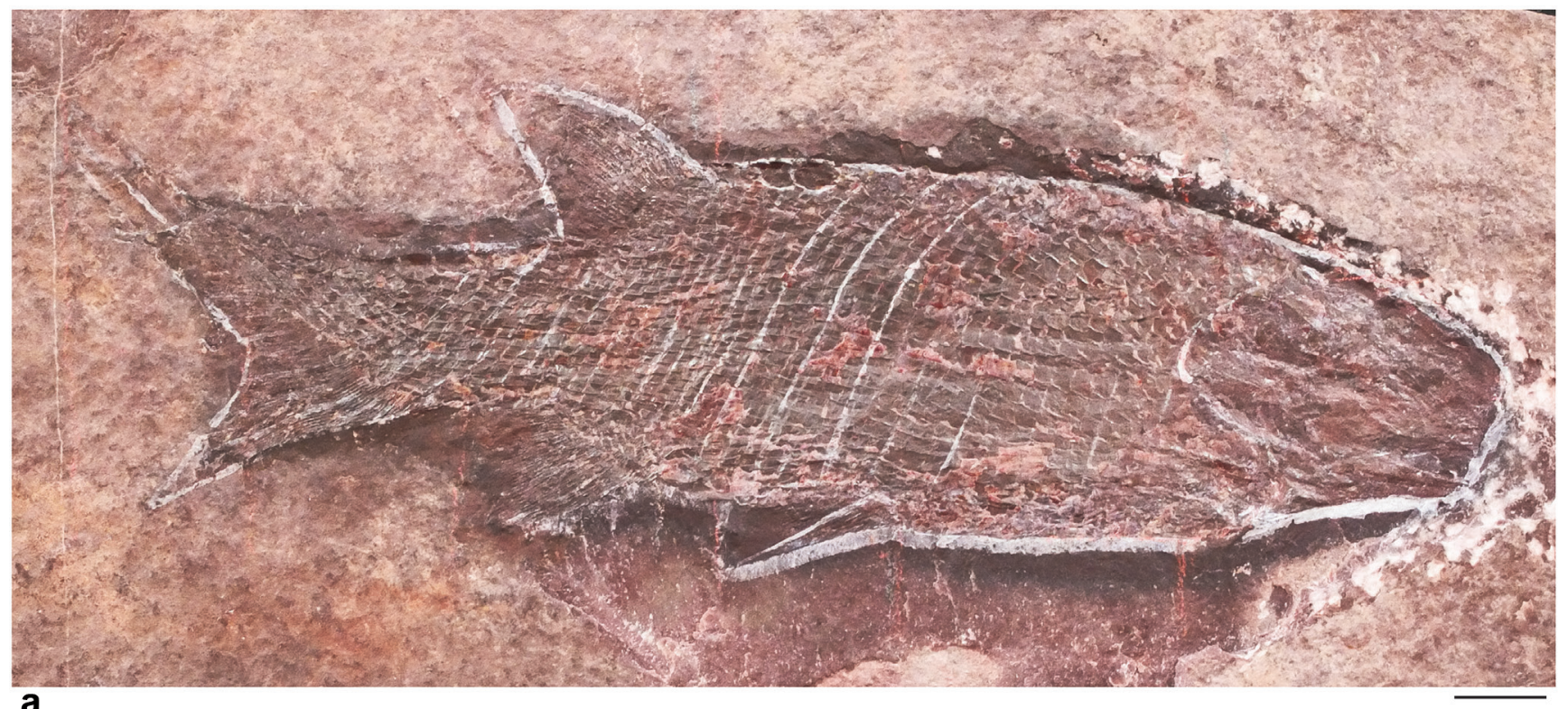

a

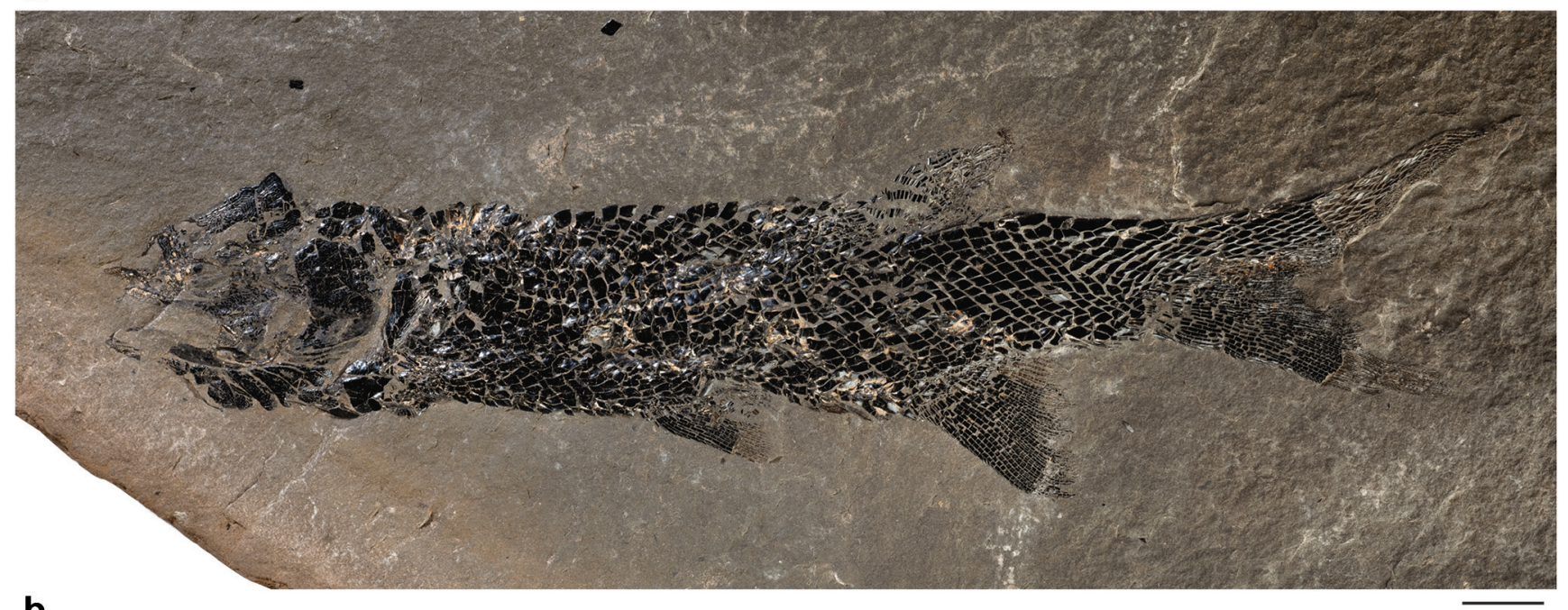

b

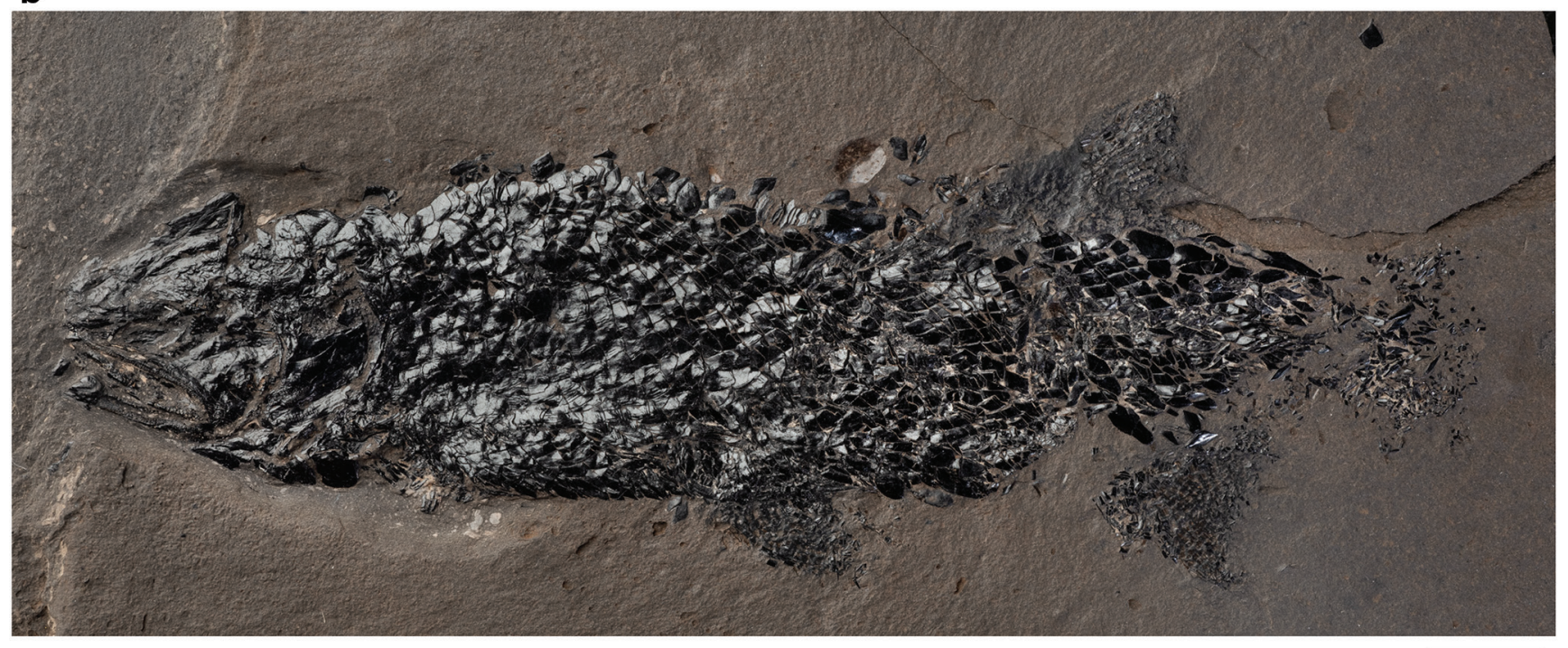

C

Text-fig. 8. a: Paramblypterus zeidleri (FriTsch, 1895), Lectotype NM-M 901 from the locality Ruprechtice, scale bar 10 mm; b: Paramblypterus cf. rohani, significantly deformed specimen from the locality Otovice "Stěnava", DP 4529, scale bar $10 \mathrm{~mm}$; c: Paramblypterus cf. rohani, significantly deformed specimen from the locality Otovice "Stěnava”, DP 4257, scale bar 10 mm.

Description of the type specimen NM-M 901. A fish of fusiform shape which may reaches a total length of $160 \mathrm{~mm}$. The total body length is 4.1 times that of the deepest part of the body and 5.6 times the length of the skull. The bones of the skull roof are indistinct and only partial contours of the maxilla, lower jaw, operculum and suboperculum, supracleithrum and 
posttemporal are visible. The maxilla has a deep quadrangular postorbital maxillary plate. The coronoids in the anterior part of the lower jaw bear numerous short teeth. The operculum is of oblong shape, slightly elongated dorsoventrally. The suboperculum is the same length as the operculum, but its depth is only $50 \%$ the depth of the operculum. The dorsoventrally elongated supracleithrum has a ventral margin which extends to the upper third of the suboperculum depth. The supracleithrum is in contact with the posttemporal dorsally.

A fragment of the pelvic fin is situated closer to the anal fin than to the skull. The base of the dorsal fin extends over a length of 7 scale rows, and a field of minute scales occurs along the fin base. This fin begins beyond the midpoint of the total body length, and the base of the dorsal fin is perpendicular to the base of the anal fin. The dorsal fin has a triangular shape which consists of 28-30 segmented lepidotrichia. The base of the anal fin extends over a length of 9 scale rows, it consists of approximately 30 segmented lepidotrichia, and similarly as in the dorsal fin, a field of small scales occurs along the fin base. Segments of the lepidotrichia in all fins are short and solid. The heterocercal caudal fin has a dorsal lobe which significantly exceeds the length of the incompletely preserved ventral lobe.

The scales covering the trunk are preserved as imprint. The scales behind the skull, similarly as in P. vratislaviensis, bear fine ridges passing diagonally across the outer surface of the scale and terminating as small denticles on the posterior edge of the scales. Fine ridges have been recorded on the scales below the lateral sensory canal in the region between the skull and pelvic fin. Fine ridges and number of denticles on scales decrease in a posterior direction, and after the $10^{\text {th }}$ scale row they are completely absent. The scales are not completely smooth, as described by Fritsch (1895), but have similar sculpture as Paramblypterus vratislaviensis. The scale count is:

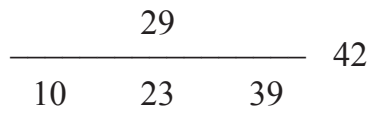

Four large ridge scales precede the base of the dorsal fin. Large scutes cover the dorsal edge of the caudal peduncle and large anteroposteriorly elongated basal fulcra continue on the dorsal edge of the dorsal lobe of the caudal fin. Two large scutes precede the basal fulcra of the ventral lobe of the caudal fin. The $23^{\text {rd }}$ row of scales in front of the anal fin contains 11 scales below the lateral sensory line and 12 scales above the lateral sensory line. The inclination of the above mentioned row of scales to the horizontal plane is $70^{\circ}$. It is $5^{\circ}-10^{\circ}$ greater than in well preserved specimens of Paramblypterus vratislaviensis or Paramblypterus cf. rohani. It is possible that under an ideal state of conservation, the base of the dorsal fin would be moved more anteriorly.

\section{Paramblypterus cf. rohani}

Text-figs 8b, c, 9-12

M a t e ri a 1. 210 fragments of bodies and isolated bones from the localities of the Otovice Limestone Horizon (Textfig. 1b).

R e m a r k s . Paramblypterus rohani (HeCKel in HeCKel et KNER, 1861) was first described from the Vrchlabí
Formation (Asselian) of the Krkonoše Piedmont Basin (Heckel and Kner 1861, Fritsch 1895, Heyler 1969, Štamberg 1976). Heyler (1971) also documented this species from the Autun Basin in the French Massif Central. Numerous anatomical features such as the skull roof bones, maxilla and bones of the cheek correspond with the features described by Dietze (1999) in Paramblypterus duvernoyi (AgAssiz, 1833). It is likely that the species Paramblypterus rohani belongs within a synonymy of Paramblypterus duvernoyi (Dietze 1999, Štamberg 2018). However, a thorough comparison of the two species has not yet been made and the species Paramblypterus rohani is still kept as valid. For this reason, the material described in the following article is compared with the specimens of Paramblypterus rohani known from the Vrchlabí Formation of the Krkonoše Piedmont Basin.

D e s cription. Bodies of fusiform shape and a total length up to $172 \mathrm{~mm}$. None of studied specimens had a complete undeformed body shape (Text-fig. 8b, c). Body fragments exhibited the slightly arched anterior part of the body (Text-fig. 10f).

Rostral part and skull roof (Text-figs 9, 10a-d). A large postrostral with short ridges and tubercles on the outer surface of the bone is preserved in specimen DP 4529. A ragment of the nasal and supraorbital anterior is situated laterally from the postrostral.

The skull roof bones are preserved in the specimens NM-M 4920, P 64658, P 64665, P 64673 and others. The frontal is of oblong shape, the length being more than twice the width including the lateral process.

The anterior edge of the frontal is straight or slightly slopes medially, the lateral edge of the bone forms the lateral process in the posterior third of its length, the process extends between the dermopterotic and dermosphenotic. The interfrontal suture is without any large processes, and is straight or slightly wavy. The dorsal surface of the frontal bears well developed sculpture including tubercles and vermicularly arranged ridges. Prominent sculpture on the frontal sometimes overlaps the interfrontal suture (Text-fig. 10a). The supraorbital sensory canal traverses along the lateral margin of the frontal. The parietal is square shaped, and often the right and left parietal differ in shape (Text-fig. 10a). The anterior, medial and posterior pit lines are well-developed. The dorsal surface of the bone bears tubercles and short ridges. The triangular shaped dermosphenotic is slightly elongated posterolaterally along the anterior margin of the dermopterotic. Ridges which are parallel with the lateral border of the bone form the sculpture on the dermosphenotic. A short section of the infraorbital canal can be observed near to the lateral edge of the bone. The dermopterotic is oblong in shape, rounded anteriorly. It slightly extends in a posterior direction and continues as a large sharply pointed process posteriorly. The lateral edge of the bone is usually straight or slightly wavy in comparison to specimen P 30943 (Text-fig. 10d) which has a lateral process in the middle of the lateral edge length. Conspicuous ridges and tubercles form the sculpture similarly as on the other bones of the skull roof. The pores of the infraorbital sensory canal can be observed along the posterior part of the lateral edge of the bone. A small postparietal of oblong shape is preserved on DP 4529. A strip of extrascapular bones (Text-fig. 9a) which consists of the extrascapular medial and paired extrascapular 

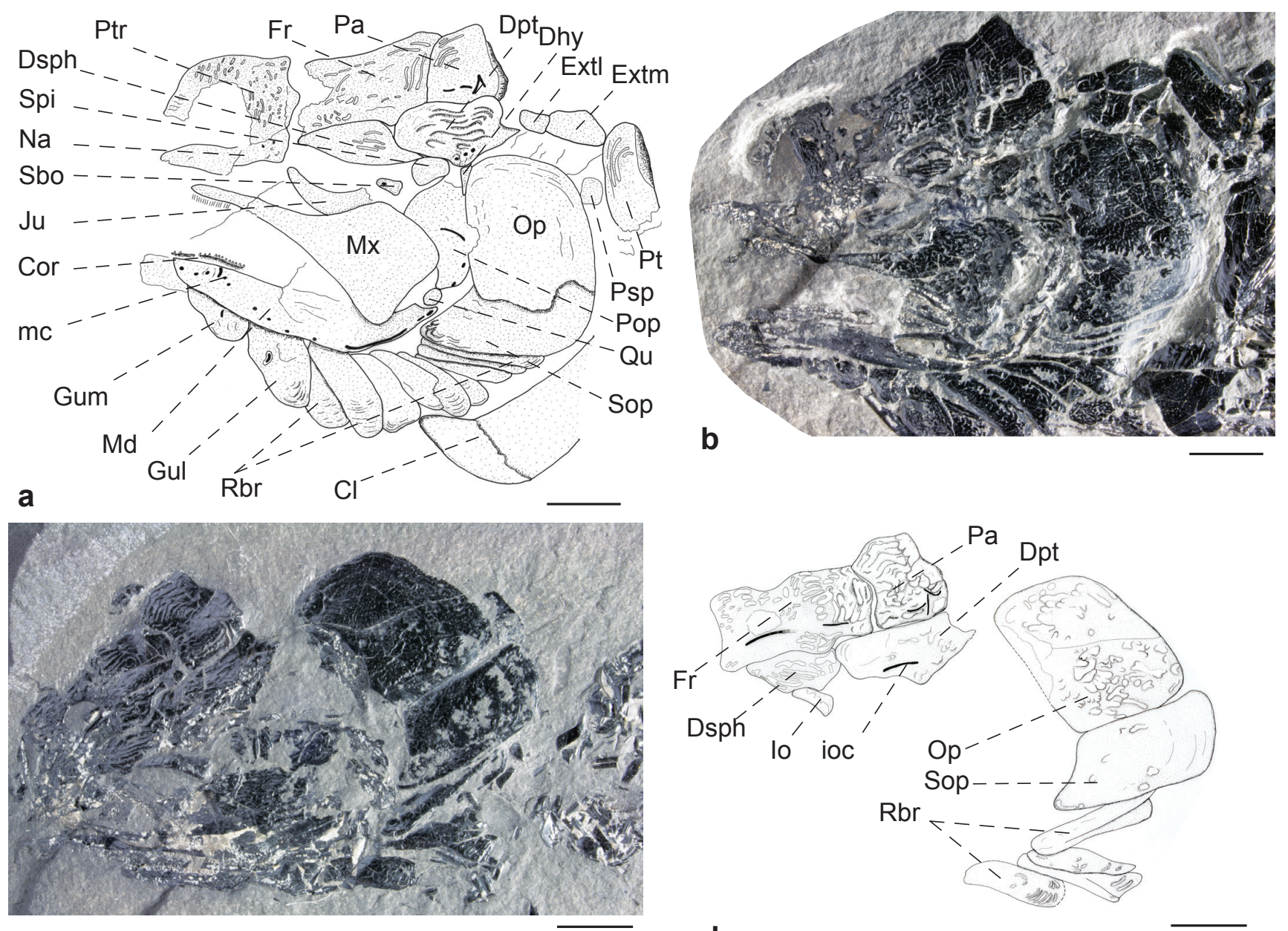

C

d
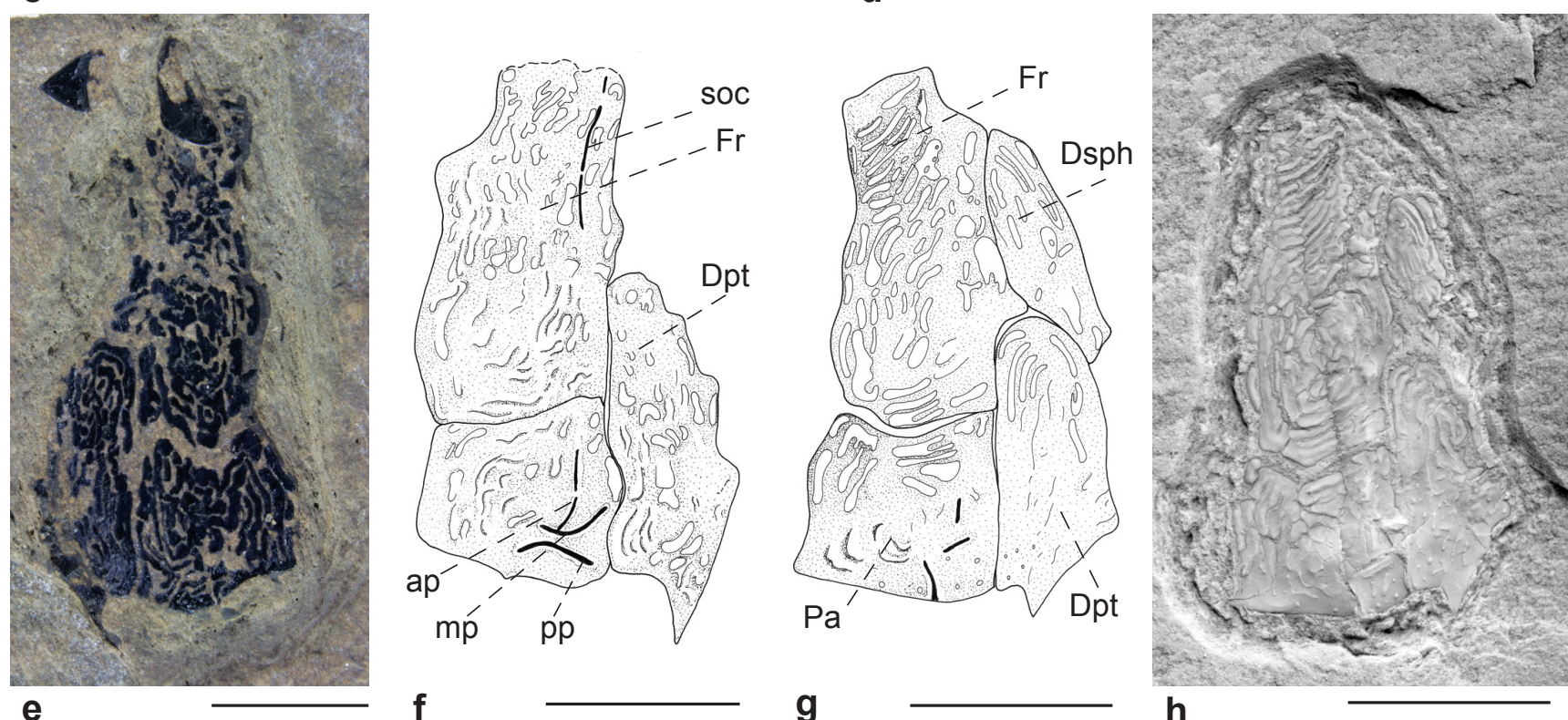

Text

Text-fig. 9. Paramblypterus cf. rohani. Scale bars $5 \mathrm{~mm}$. a, b: drawing and photograph of the skull in lateral view, locality Otovice "Stěnava", DP 4529; c, d: photograph and drawing of the skull in lateral view, locality Otovice "Chmelnice", P 64673; e: bones of the skull roof in dorsal view, locality Otovice "Chmelnice", P 64656; f: bones of the skull roof in dorsal view, locality Otovice "Chmelnice", P 30945; g, h: drawing and photograph (whitened) of the bones of the skull roof in dorsal view, locality Otovice “Chmelnice", P 64658. Abbreviations: ap - anterior pit line, Cl - cleithrum, Cor - coronoid, Dhy - dermohyal, Dpt - dermopterotic, Dsph - dermosphenotic, Extl - extrascapular lateral, Extm - extrascapular medial, Fr - frontal, Gul - lateral gular, Gum - medial gular, ioc - infraorbital canal, Ios - infraorbital superior, Ju - jugal, mc - mandibular canal, Md - mandible, Mx - maxila, mp medial pit line, Na - nasal, Op - operculum, Pa - parietal, Pop - preoperculum, pp - posterior pit line, Psp - postspiracular, Pt - posttemporal, Ptr - postrostral, Qu - quadratum, Rbr - branchiostegaly rays, Sbo - suborbital, soc - supraorbital canal, Sop - suboperculum, Spi - spiracular. 


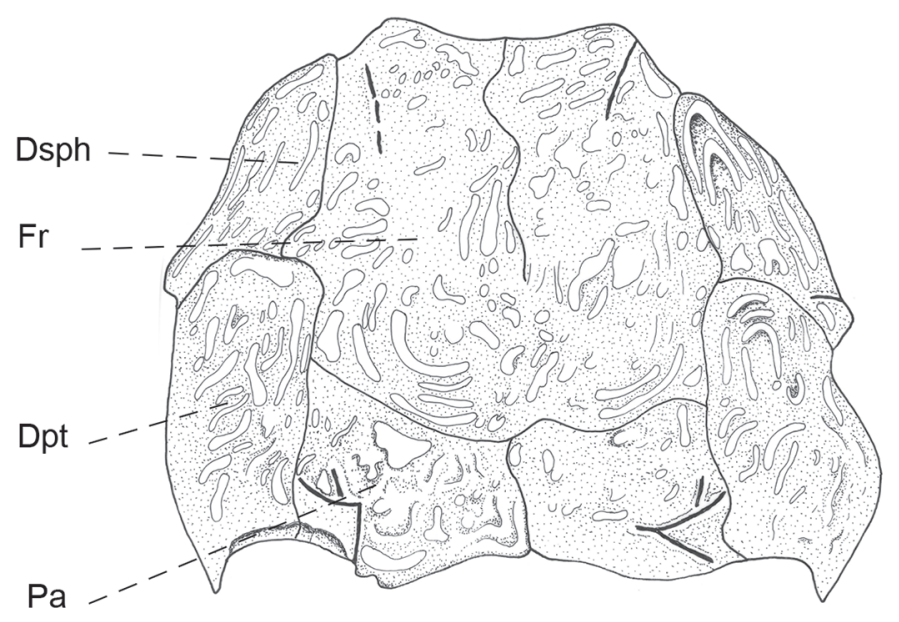

$\mathrm{Pa}$

$\mathbf{a}$

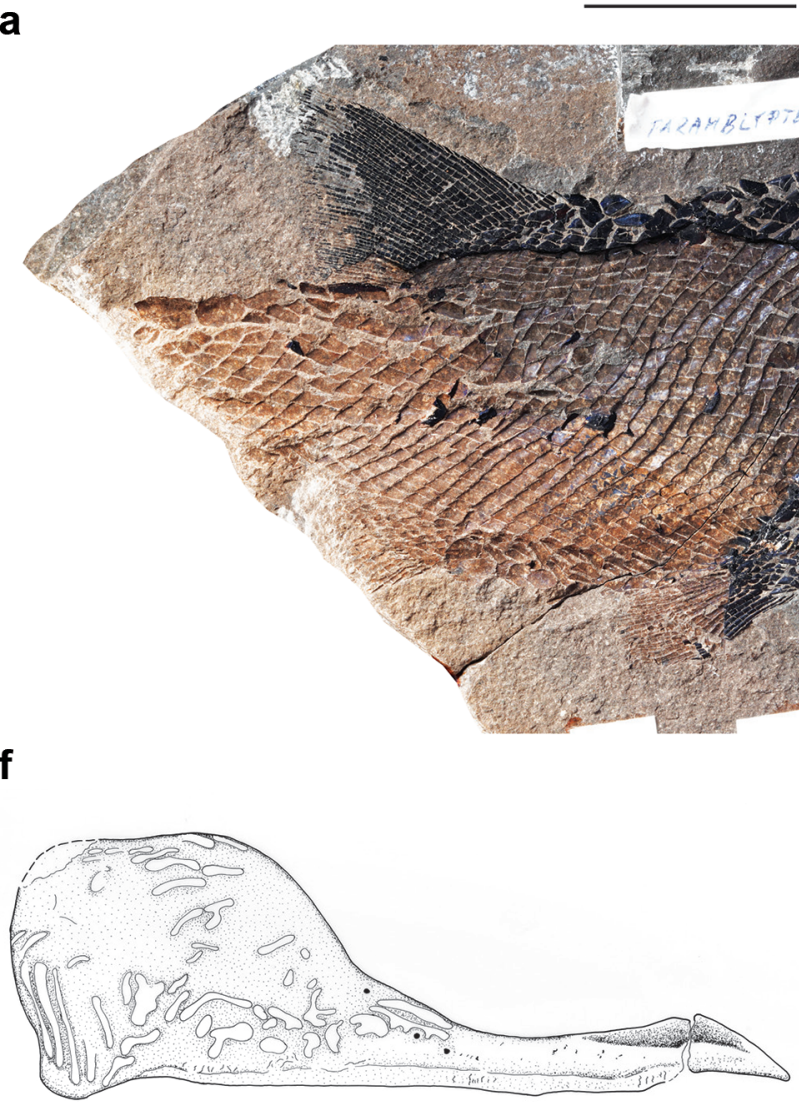

9

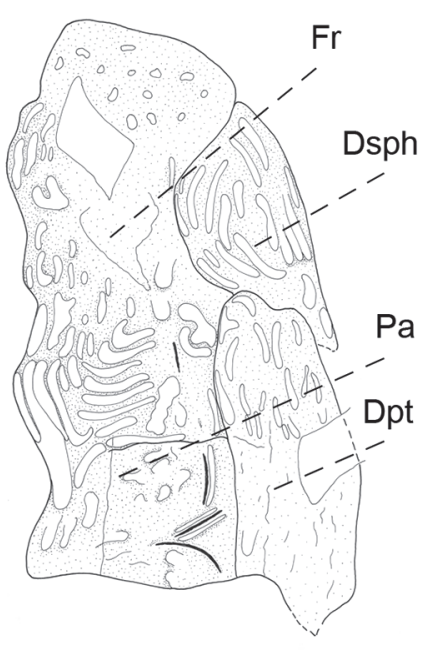

b

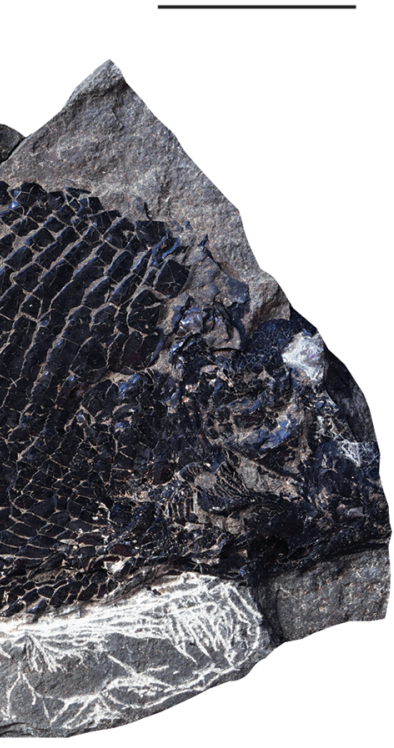

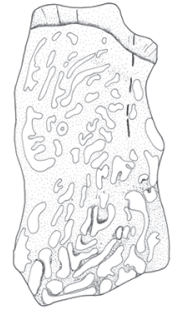

C

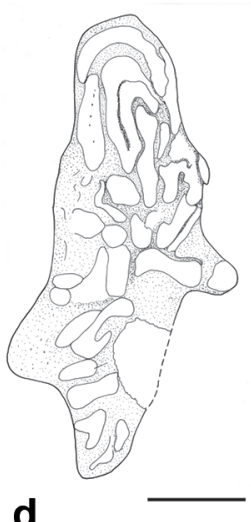

d

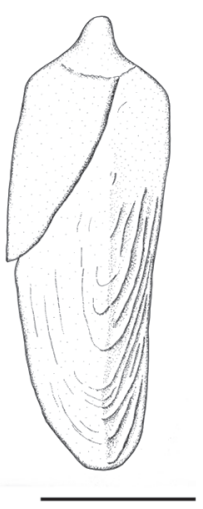

e

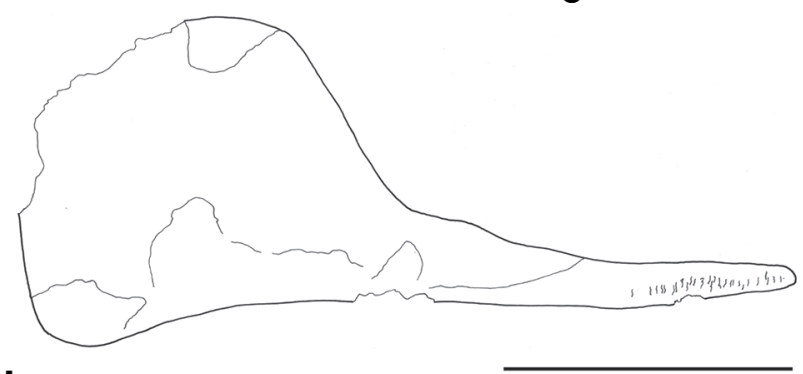

h

Text-fig. 10. Paramblypterus cf. rohani. a: the skull roof in dorsal view, locality Otovice "Chmelnice", P 64665, scale bar 5 mm; b: bones of the skull roof in dorsal view, locality Otovice "Chmelnice", NM-M 4920, scale bar 5 mm; c: right frontal in dorsal view, locality Otovice "Chmelnice", NM-M 4923, scale bar 5 mm; d: right dermopterotic in dorsal view, locality Otovice "Chmelnice", P 30943, scale bar 2 mm; e: right supracleithrum in lateral view, locality Otovice "Chmelnice", P 30944, scale bar 5 mm; f: fragment of not deformed body in lateral view, locality Otovice "Chmelnice", NM-M 4916, scale bar 10 mm; g: right maxilla in lateral view, locality Otovice "Chmelnice", P 64661, scale bar 5 mm; h: right maxilla in lateral view, locality Otovice "Chmelnice", NM-M 4922, scale bar 5 mm. Abbreviations: Dpt - dermopterotic, Dsph - dermosphenotic, Fr - frontal, Pa - parietal.

lateral borders the parietal and dermopterotic posteriorly. The extrascapular medial (DP 4529) is lateromedially elongated with a convex anterior edge. The extrascapular lateral is also slightly mediolaterally elongated and bears several pores of the occipital canal (P 30945).

Jaws and cheek bones (Text-figs 9a, b, 10g, h, 11a). Specimens DP 4529, P 30949, P64661, P 64672 and others exhibit a maxilla and other cheek bones. The maxilla has a typical "amblypterid" shape with large maxillary plate. The depth of the maxillary plate increases slightly posteriorly and the length of the maxillary plate exceeds its depth. The maxillary plate is straight dorsally and extends posteroventrally as a small blunt process. Long ridges parallel with the posterior edge of the bone form sculpture on the 
posterior area the maxillary plate. Two or three pores of the sensory canal are situated in the transition zone between the maxillary plate and the narrowed suborbital part of the maxilla (Text-fig. 10g). The sickle-shaped jugal borders the maxilla anteriorly. The infraorbital superior is another bone located in front of the dorsal part of the maxillary plate. The infraorbital superior is in contact anteriodorsally with the dermopterotic and together with the jugal forms part of the posterior and dorsal limit of the orbit. Pores on the infraorbital superior indicate the course of the infraorbital sensory canal from the dermopterotic to the jugal. A relatively large spiracular of oval shape extends laterally to the dermopterotic and dermosphenotic. The preoperculum, broadens conspicuously anteriorly and narrows posteriorly, and borders the maxillary plate dorsally and posteriorly. The narrow ventroposterior part of the preoperculum is tightly wedged between the maxillary plate and the suboperculum. The preopercular sensory canal traverses from the angular to the preoperculum, it then continues along the posterordorsal edge of the preoperculum. The sensory canal bends at the transition between the narrow and enlarged part of the bone and also at the same point a short conspicuous pit line branches (DP 4257, DP 4529).

The lower jaw broadens slightly in a posterior direction and it forms a large dorsal process posteriorly which forms a joint with the quadrate above the articular. The dorsal process of the lower jaw extends into the anteroventral corner of the suboperculum. The dentalosplenial bears several pores marking the course of the mandibular sensory canal. The mandibular sensory canal passes more closely to the dorsal edge of the anterior area of the dentalosplenial, in addition there is a distint dorsoventrally arranged pit line (Text-fig. 9a, b). The mandibular sensory canal posteriorly passes along the ventral edge of the dentalosplenial, it bends dorsally and traverses to the angular where it continues to the preoperculum. Marginal dentition on the lower jaw and maxilla is formed of tubular teeth. Short strong teeth on the coronoids can be seen partly preserved on DP 4529.

The triangular shaped dermohyal located along the dorsal part of the operculum is wedged between the operculum and preoperculum (Text-fig. 9a, b). Fragments of other bones between the orbit and preoperculum were not determinable.

Opercular apparatus (Text-figs 9a-c, 11c). The operculum, suboperculum, branchiostegal rays, lateral and median gulars form the dermal bones of the opercular apparatus. The oblong shaped operculum is only slightly elongated in the dorsoventral direction (DP 4529, P 64664, $\mathrm{P}$ 64673, P 64890) and has a depth to length ratio of 1.2 to 1.3. The operculum is longest in its ventral part and slightly

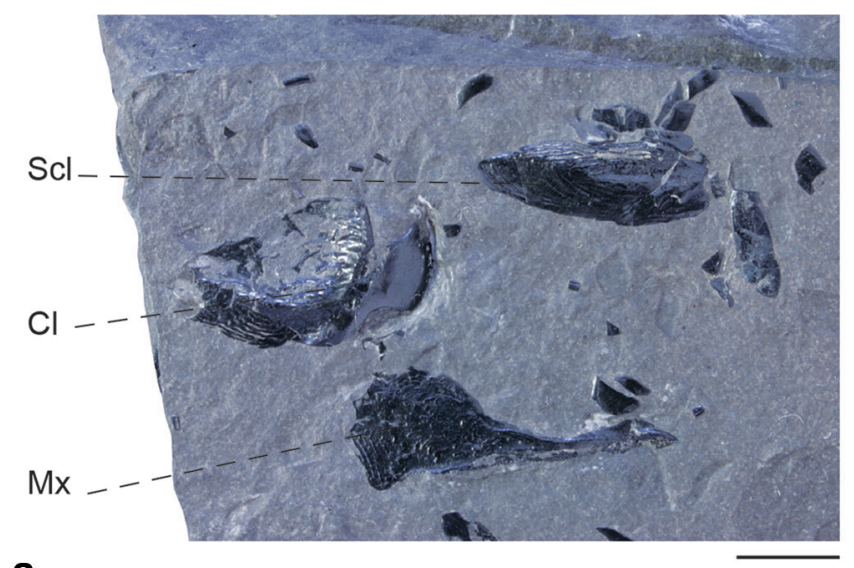

a

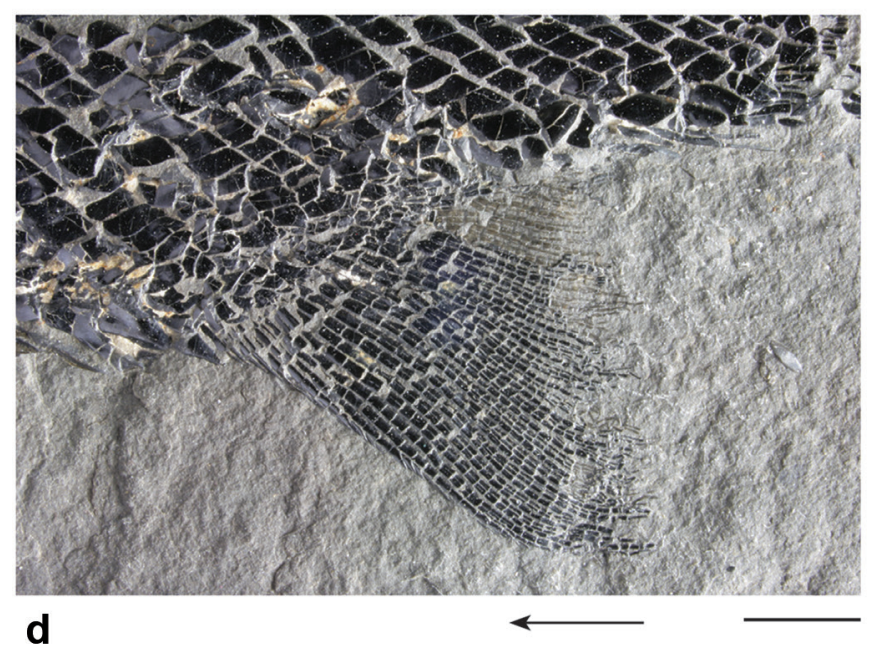

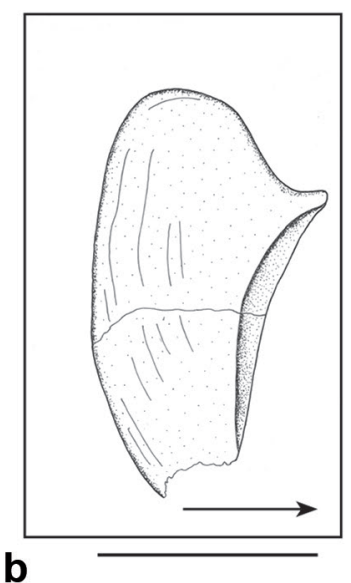
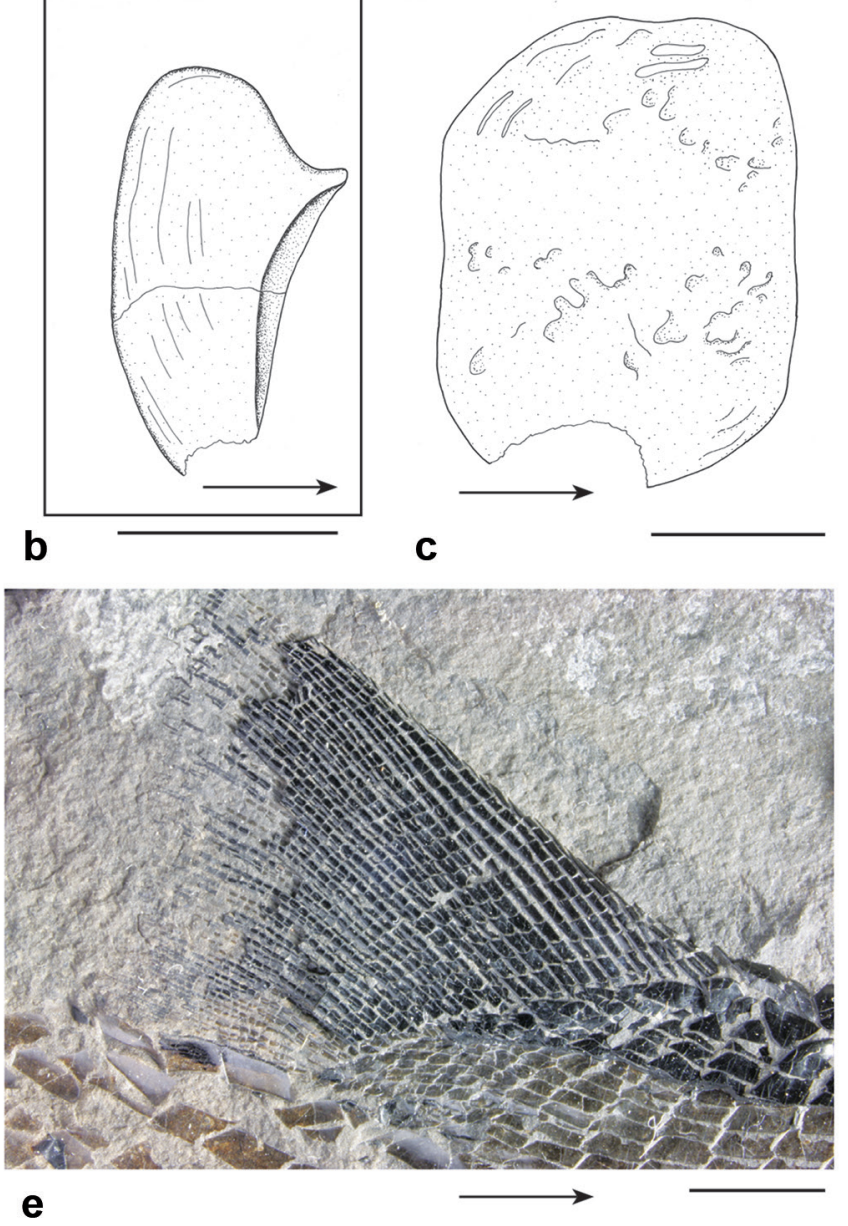

Text-fig. 11. Paramblypterus cf. rohani. Arrows indicate directio cranialis. Scale bars $5 \mathbf{~ m m}$. a: isolated maxilla, cleithrum and supracleithrum in lateral view, locality Otovice "Chmelnice", P 64661; b: left posttemporal in dorsal view, locality Otovice "Chmelnice", P 64664; c: right operculum in lateral view, locality Otovice "Chmelnice", P 64883; d: anal fin, locality Otovice "Stěnava", DP 4529; e: dorsal fin, locality Otovice "Chmelnice”, NM-M 4916. Abbreviations: Cl - cleithrum, Mx - maxilla, Scl - supracleithrum. 
narrows dorsally. All corners of the bone are rounded. The operculum is twice the depth of the suboperculum. The suboperculum (P 64673, DP 4257, DP 4529) is of oblong shape with an anteroventral process and the depth of the suboperculum with anteroventral process is $50 \%$ the length of the suboperculum. Nine branchiostegal rays follow ventrally from the suboperculum (DP 4529). As far as their placement is concerned three branchiostegal rays are located ventrally from the mandible and six branchiostegal rays are located between the ventroposterior corner of the mandible and the suboperculum (Text-fig. 9a, b). Distal areas of the outer surface of the branchiostegal rays bear ridges parallel with the posterior edge of the bones. Paired gular (DP 4529, P 64675) are larger than the following branchiostegal rays. They are sharply pointed anteriorly, rounded posteriorly and concave medially. The median gular of diamond shape is conspicuously smaller than the lateral gular. Both the median and lateral gulars bear pit lines. In the lateral gular they appear as a short simple groove and a Y-shaped groove on the median gular. Median and lateral gulars border two thirds of the lower jaw length.

Pectoral girdle (Text-figs 9a, b, 10e, 11a, b). The oval shaped posttemporal on NM-M 4529, NM-M 4915, P 64664 attaches to the extrascapular bones posteriorly. A conspicuous process arising from the posttemporal is wedged between the extrascapular lateral and supracleithrum. The dorsoventrally elongated supracleithrum (P 30944, P 64661) continues ventrally from the posttemporal and articulates with the posttemporal via a large process on the dorsal edge of the supracleithrum. A lateral sensory line diagonally crosses the dorsal third of the supracleithrum and traverses the lateral side body scales. A small rounded postspiracular is preserved on DP 4529 (Text-fig. 9a, b). This bone occupied a position among the posttemporal, supracleithrum and operculum during the animal's lifetime. The cleithrum and the clavicle are very poorly preserved on DP 4529.

In NM-M 4915 the bordering of the postcleithrum on the posterior edge of the cleithrum is unusually well preserved (Text-fig. 12f, g). It is actually a large scale, two and half times deeper than the following scales that anteriorly overlap the ventral part of the supracleithrum and dorsal part of the cleithrum. The posterior edge of the postcleithrum contains only a few denticles on its ventral part. The outer surface bears fine ridges arranged in a dorsoventral direction. They are similar to the ridges on the posterior area of the supracleithrum, and this sculpture differs significantly from the distinctive ridges on the surrounding scales.

Fins. The pelvic fin consists of 16-17 segmented lepidotrichia (P 64687, DP 4529) and its base extends over 4 scale rows. The pointed segments of the first four lepidotrichia terminate at the anterior edge of the fin where they alternate with fulcral scales.

The dorsal fin (Text-fig. 11e) consists of 30-31 lepidotrichia and its base extends over a length of 7 scale rows (NM-M 4916, NM-M 4928). Along the base of the fin a field of minute scales are located. The posterior edge of the minute scales is serrated. The pointed segments of the first nine lepidotrichia terminate at the anterior edge of the fin where they alternate with the fulcral scales. The longest lepidotrichia of the dorsal fin in adult specimens are composed of 32-35 segments.
The anal fin (Text-fig. 11d) consists of about 30 segmented lepidotrichia and its base extends over a length of 8.5-9 scale rows. A field of minute scales is located along the anal fin base as in the dorsal fin and the pointed segments of lepidotrichia together with the fulcral scales protect the anterior edge of the anal fin.

The caudal fin is significantly heterocercal. The pointed segments of the first nine lepidotrichia of the ventral lobe of the caudal fin terminate at the anterior edge of the fin where they alternate with fulcral scales (DP 4529). In specimen DP 4529 the total length of the body is $170 \mathrm{~mm}$ and segments of the fins are narrow and long which indicates that it is not an old individual and further growth of the fish could have been expected. On the contrary specimen P 64668 which will be discussed separately, is $145 \mathrm{~mm}$ long and the segments of the fin lepidotrichia are wide and short, which indicates a relatively old adult individual.

Squamation (Text-fig. 12). The squamation consists of thick scales with peg and socket articulation. Their shape, sculpture and serration on the posterior edge varies depending on their location on the body. Large scales of oblong shape which are deeper than they are long are situated along the lateral sensory line in the anterior area of the body. Rhombic shaped scales are located more posteriorly, while very narrow long scales cover the abdominal area of the body. The scales covering most of the trunk have a smooth surface, but the scales in the anterior part of the body bear relatively pronounced sculpture and serration on their posterior edge (P 30945, NM-M 4915, NM-M 4924 a others). Specimen NM-M 4915 demonstrates squamation in more detail. In scales of the first five rows below the lateral sensory line, the whole posterior edge is serrated. The scales below the lateral sensory line have 10 denticles. The posterior edge of the scales bearing pores of the lateral sensory canal also bears denticles. There are pronounced diagonal ridges on the outer surface of the scale which lead to each denticle. The degree of serration on the posterior edge of the scales decreases in a posterior direction. Denticles are absent on the scales of the eighth row of the lateral sensory line. In other scales serration is significantly decreased compared to the scales of the tenth row. The last scale with several denticles occurs in the $15^{\text {th }}$ row. Scales with sculpture and serration of their posterior edge are not preserved in all specimens. Sometimes the ridges on the surface of the scales and serration of their posterior edge are observable on only a limited number of scales just behind the skull or only on some scales. I am convinced these differences are not due to species distinctions but to variability of the squamation. Serration of the posterior edge of the scales is also exhibited in the minute scales occurring along the base of the anal and dorsal fins (DP 4529), on the contrary this serration is missing in other specimens (NM-M 4928).

Specialised scales lie in front of the dorsal and anal fins and on the caudal fin in addition to the scales arranged in diagonal rows. Four large smooth ridge scutes without serration on their posterior edge precede the base of the dorsal fin (NM-M 4929, P 80178). One median and one pair of large scutes are located in front of the anal fin. The dorsal edge of the caudal peduncle and dorsal lobe of the caudal fin cover dorsal scutes in a similar manner as does the ventral edge of the caudal peduncle. A series of fringing fulcra cover the posterior part of the caudal fin dorsal margin. 


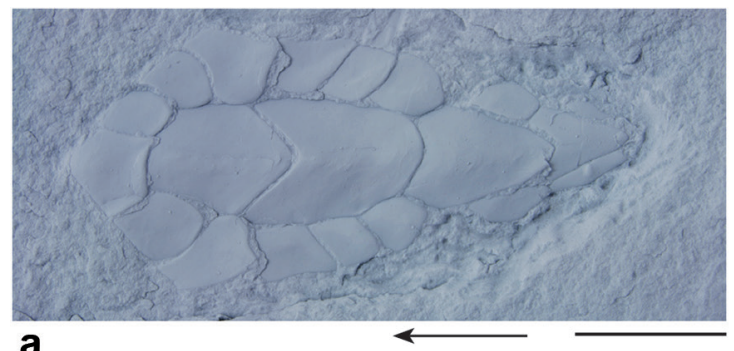

a

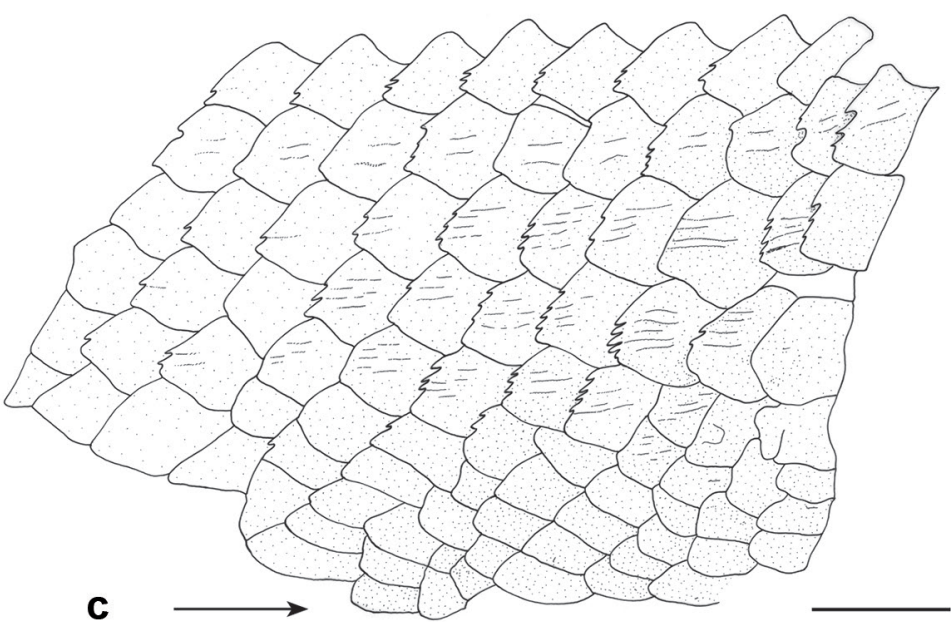

b
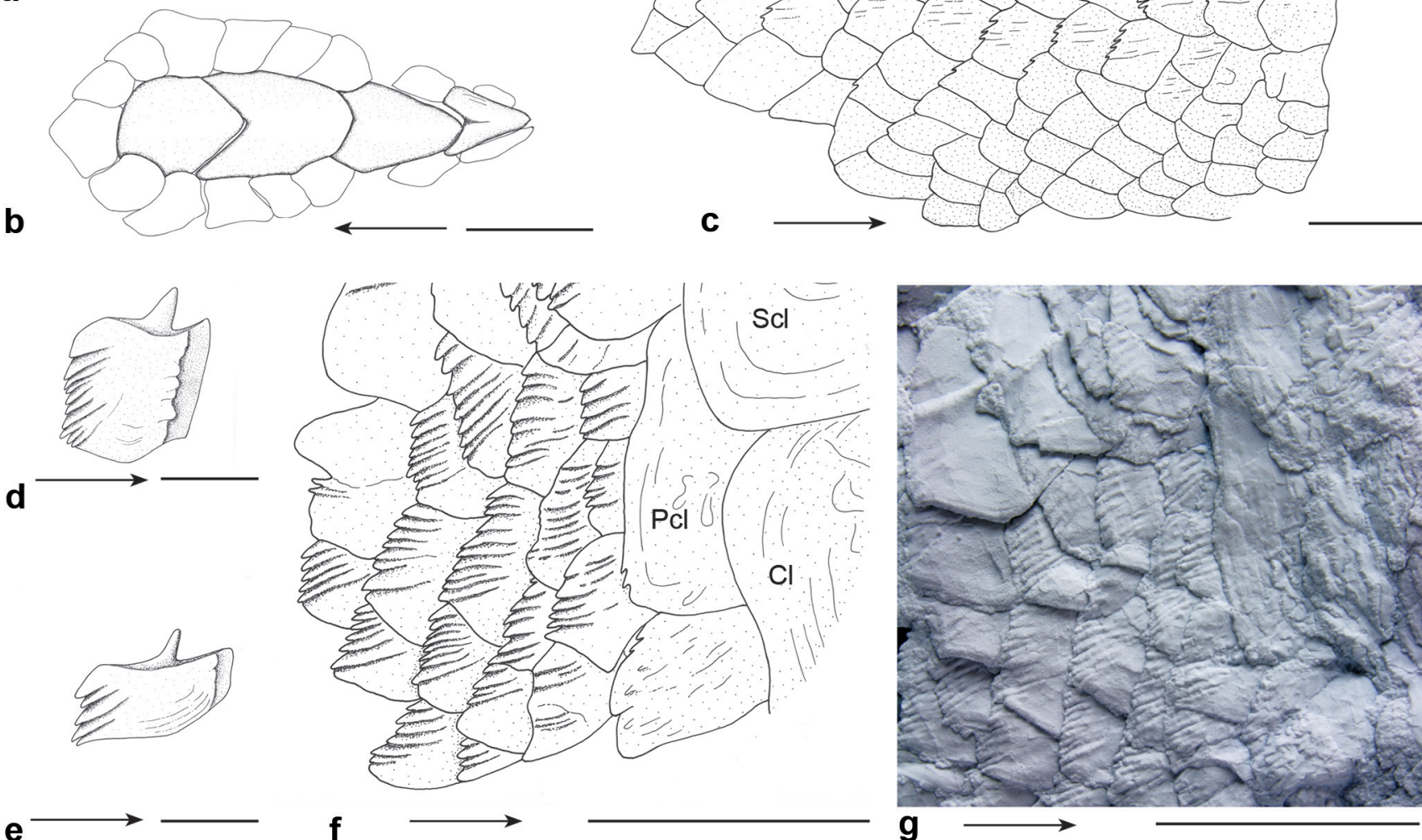

e

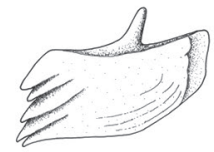

Text-fig. 12. Paramblypterus cf. rohani. Arrows indicate directio cranialis. a, b: photograph and drawing of four ridge scales in front of the dorsal fin base, locality Otovice "Chmelnice", P 80178, scale bars $5 \mathrm{~mm}$; c: scale rows from the area between the pectoral and pelvic fins, outer surfaces of the scales bear fine ridges terminating as denticles on the posterior edge of the scales, locality Otovice "Chmelnice", NM-M 4916, scale bar $5 \mathrm{~mm}$; d: isolated scale, from anterior area of the lateral side of the body, with denticulated posterior edge, locality Otovice "Chmelnice", P 30945, scale bar $2 \mathrm{~mm}$; e: isolated scale from the pelvic area of the body, locality Otovice "Chmelnice", P 30945, scale bar 2 mm; f, g: drawing and photograph of the postcleithrum and the scales behind the pectoral girdle (the scales bear conspicuous ridges on their outer surface; well preserved large postcleithrum is without ridges.), locality Otovice "Chmelnice", NM-M 4915, scale bars 5 mm. Abbreviations: Cl - cleithrum, Pcl - postcleithrum, Scl - supracleithrum.

The juvenile specimen in P 30947 has a total body length of $37 \mathrm{~mm}$ and also belongs to Paramblypterus cf. rohani. The specimen has scales developed only posteriorly to the dorsal fin. Segments of the lepidotrichia on the fragments of the dorsal and caudal fins are narrow, very long and few in number. The longest lepidotrichia of the caudal fin have only 8 segments. Ridge scale on the dorsal lobe of the caudal fin exhibits fusion of several scales.

\section{Paramblypterus sp.}

Text-fig. 13

M a t e r i a 1 . Specimen P 64668 from Otovice Limestone from the locality Otovice "Chmelnice".

Des c ription. Specimen with a fusiform body shape $147 \mathrm{~mm}$ of the total body length. The body is anteriorly not as arched as in Paramblypterus cf. rohani. The body length/ depth ratio is 4.9. The dorsal and anal fins are large, the pelvic fin is closer to the pectoral fin than to the anal fin. Only the outline of the skull shape is preserved. The skull length would fit into the total body length 5.9 times. The pelvic fin consists of approximately 15 segmented and dichotomously branching lepidotrichia and its anterior edge is protected by the terminal pointed segments of five anteriorly situated lepidotrichia. The large anal fin of triangular shape consists of 26 segmented and dichotomously branching lepidotrichia, and it starts at the level of the middle of the dorsal fin base. The base of the anal fin extends over a length of 8 scale rows. The large dorsal fin begins in the middle of the total body length and similarly as in anal fin has approximately 26 segmented and dichotomously branched lepidotrichia. The anterior edge of the fin is protected by pointed terminal segments of six anteriorly situated lepidotrichia in combination with several fringing 


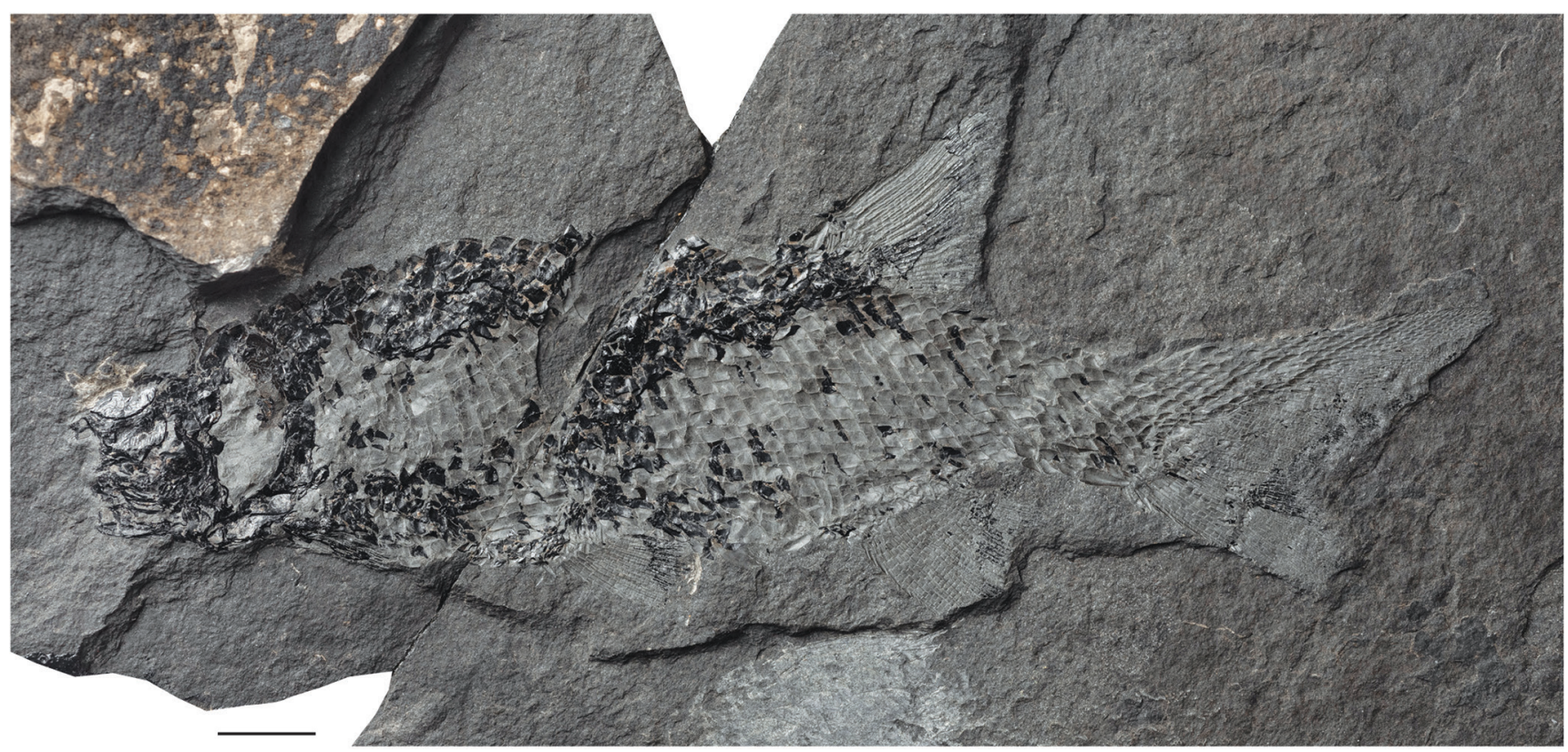

Text-fig. 13. Paramblypterus sp. Locality Otovice “Chmelnice”, P 64668, scale bar 10 mm.

fulcra. The anal and dorsal fins are very large and form more than $11 \%$ of the total area of the body including fins in lateral view. Comparing the area of the anal and dorsal fins with the total body area in lateral view with other species of the genus Paramblypterus, this ratio is about $9 \%$ in Paramblypterus vratislaviensis, in Paramblypterus zeidleri $7 \%$ and in Paramblypterus rohani from Rudník Horizon of Krkonoše Piedmont Basin 7.8-9.1\%. The dorsal and ventral lobes of the caudal fin make an angle of $43^{\circ}$. The ventral lobe consists of 15 short segmented lepidotrichia. The segments of all the fins are short and wide which indicates that it was an adult specimen. Almost the whole body is preserved as an outprint and the morphology of the scales is indistinct. Fine ridges on the surface of the scales and their serrated posterior margin are observable only on a number of scales in the anterior area of the body. The scale count is

\begin{tabular}{lll} 
& 28 & \\
\cline { 1 - 2 } & 21 & 38
\end{tabular}

\section{Remarks and relations to Amblypteridae}

Permian sediments of the Ruprechtice and Otovice Limestone horizons contain three types of paramblypterids. Paramblypterus vratislaviensis dominates in the Ruprechtice Limestone Horizon and rarely occurs in the Otovice Limestone Horizon; Paramblypterus zeidleri is very rare in the Ruprechtice Limestone Horizon; Paramblypterus cf. rohani and Paramblypterus sp. are limited to the Otovice Limestone Horizon. Parmblypterus vratislaviensis is characterized by several features which separate this species from Paramblyterus cf. rohani and Paramblypterus sp. including the size of the body usually being $100-120 \mathrm{~mm}$ of the total length; concave anterior edge of the frontals; triangular shaped dermosphenotic but very narrow where anteroposteriorly elongated; the dermopterotic anteriorly narrower than in the posterior part, and with lateral process; maxilla with short and high maxillary plate, dorsally convex.

Specimens from the Otovice Limestone Horizon possess many characters identical to those described in Paramblypterus rohani which is widespread in the Rudník Horizon (Vrchlabí Formation) of the Krkonoše Piedmont Basin (Štamberg 1976) and Autun Basin in the French Massif (Heyler 1969, 1971). The specimens from the Otovice Limestone Horizon are fragmentally preserved, they are however referred here to Paramblypterus cf. rohani. Paramblypterus cf. rohani frontal has a straight anterior edge, the dermosphenotic is of triangular shape, but wide posteriorly, the dermopterotic is oblong in shape and not narrow anteriorly, with a large process posteriorly. A slight difference from Paramblypterus rohani can be seen in the shape of the operculum which in the specimens from Otovice Limestone Horizon is slightly narrower dorsally and the suboperculum is low and its depth is $50 \%$ of the operculum depth. The total body length of the specimens is $150-180 \mathrm{~mm}$.

Paramblypterus sp. was separated from the set of specimens from Otovice Limestone on the basis of its large dorsal and anal fins, less arched trunk in the anterior part of the body and size of the dorsal and anal fins.

It can be stated that Paramblypterus vratislaviensis and other fishes similar to Paramblypterus sp. occurred in the Prosečné Formation of the Krkonoše Piedmont Basin as well as in the Intra-Sudetic Basin and their morphological and anatomical features will be further described during study of the actinopterygians of the Krkonoše Piedmont Basin.

\section{Aeduellidae RoMer, 1945 \\ Text-figs 14-17}

Material. A total of 20 specimens (DP 4307, G 58, NM-M 4910, NM-M 4911a, b, NM-M 4912, NM-M 4913, NM-M 4914, NM-M 4921, NM-M 4930, NM-M 4931, 


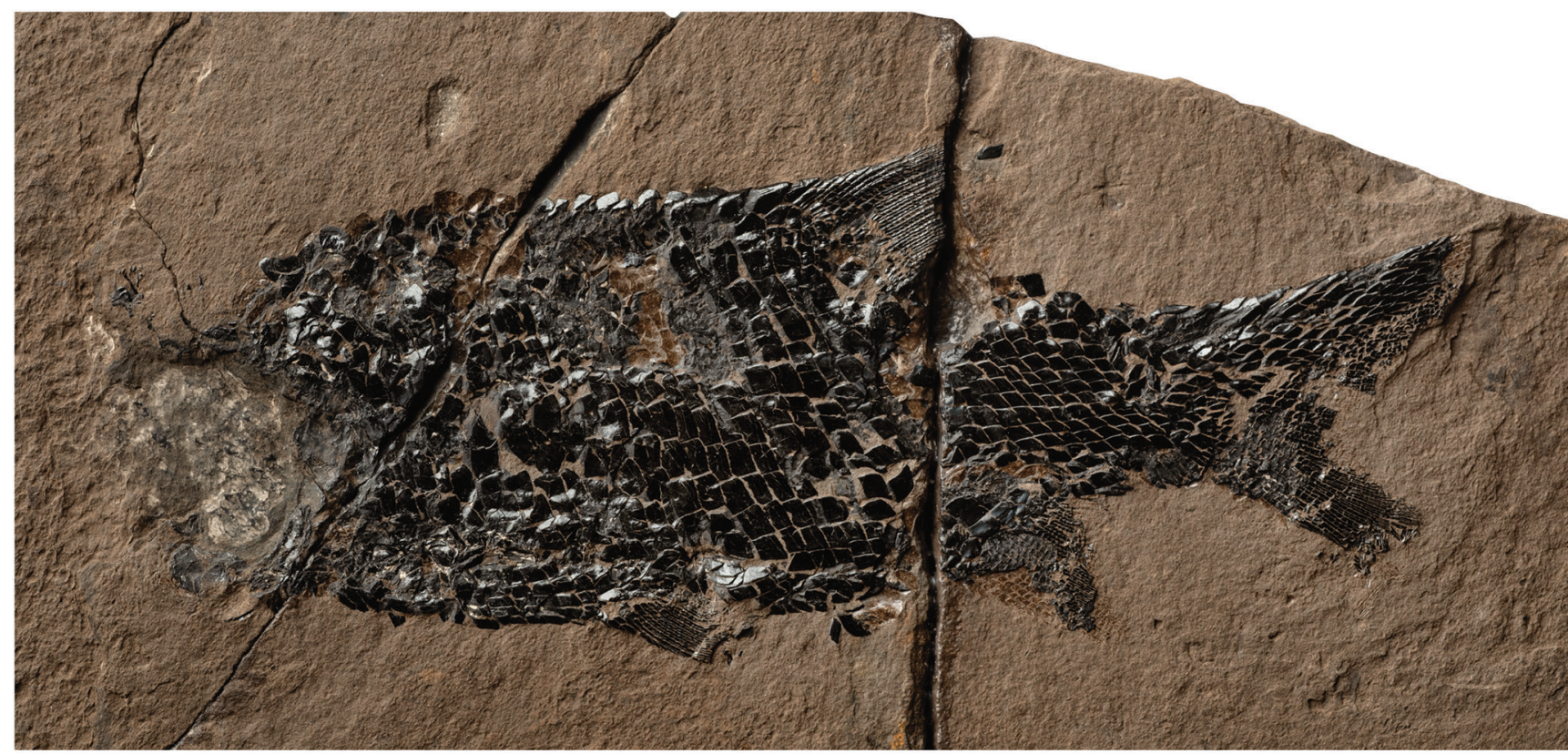

a

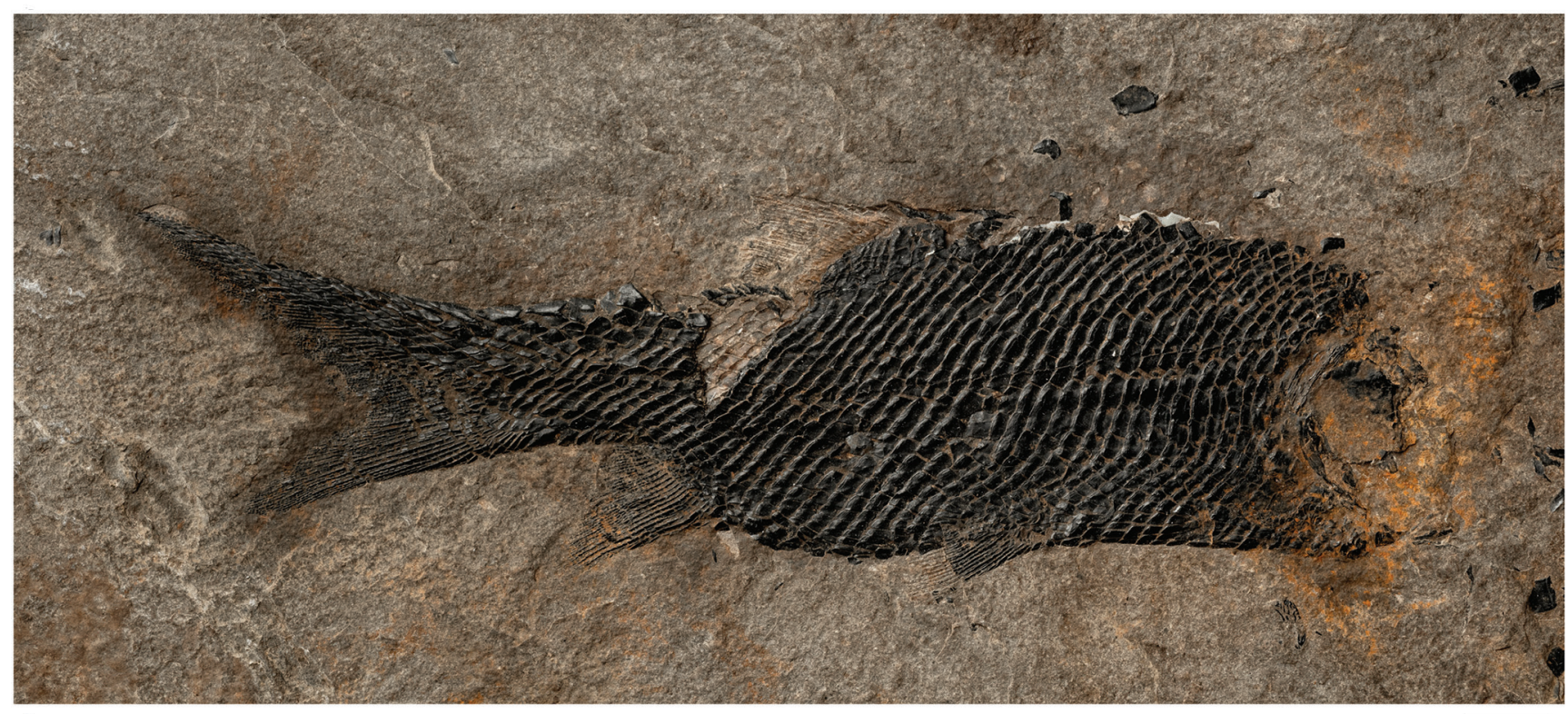

b

Text-fig. 14. Aeduellidae. a: specimen DP 4307, locality Otovice "Stěnava", scale bar 10 mm; b: specimen NM-M 4931, locality Otovice, scale bar $10 \mathrm{~mm}$.

P 30942, P 30948, P 64650, P 64651, P 64662, P 64678, P 64692, P 64886, P 64892, P 80169, P 80179) from the Otovice Limestone Horizon (Olivětín Member) of the IntraSudetic Basin, from the localities Otovice "Černý potok", Otovice "Stěnava", Otovice "Chmelnice".

Description. A small but robust body of fusiform shape (Text-fig. 14a) with a total length up to $16-20 \mathrm{~cm}$ with dorsally arched trunk (DP 4307). The skull length is $20 \%$ of the total body length, and the body length/depth ratio is about 3.5. Significant differences in the shape of the body are exhibited in specimen NM-M 4931 (Text-fig. 14b) which is described at the end of the description of Aeduellidae.

Skull roof (Text-fig. 15b, c, d). The skull is rounded anteriorly and the skull roof bones are preserved on specimen NM-M 4910. The frontal is of oblong shape with a straight anterior and lateral edge. The interfrontal suture is slightly wavy. The length of the bone is only 1.6 times its width and 1.1 times the length of the parietal. The frontal borders laterally with the dermosphenotic and dermopterotic. The parietal is square shaped or narrower than where its length. The anteroposteriorly elongated dermosphenotic forms a lateral projection lateroposteriorly and, together with the dermopterotic, borders the frontal laterally. The dermopterotic is of oblong shape, narrowing posteriorly. One pair of narrow lateromedially elongated extrascapulars meet in the midline posteriorly to the right and left parietals. All bones of the skull roof exhibit sculpture formed of short ridges and tubercles (NM-M 4910, P 64892). The traces of the sensory canals are clearly visible. A supraorbital sensory canal passes along the lateral edge of the frontal, it bends in the posterior region of the bone laterally and traverses to 

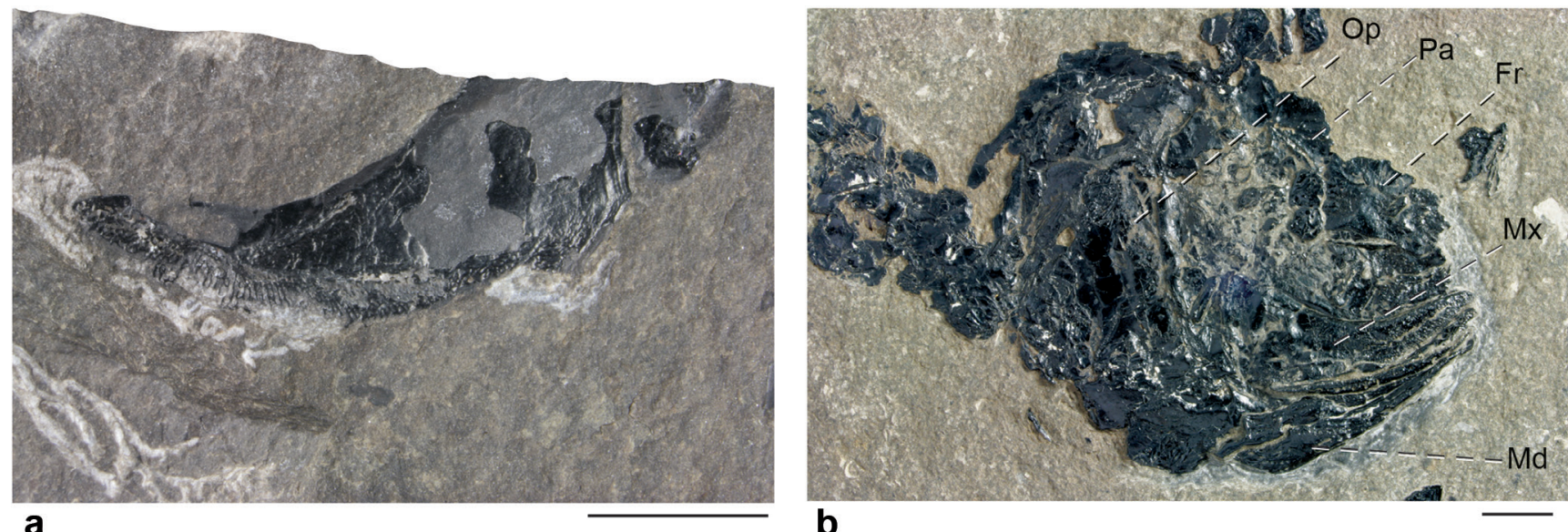

a

b
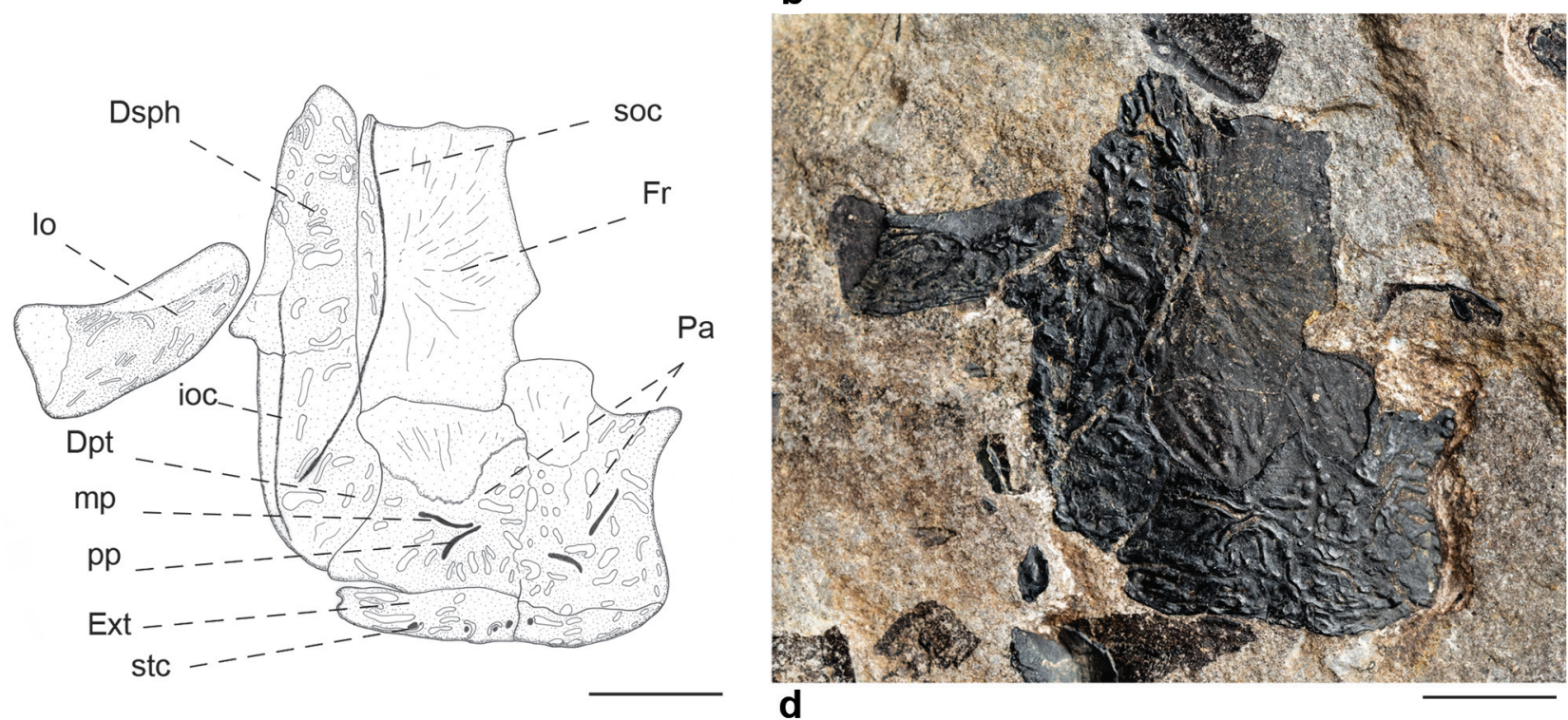

C

Text-fig. 15. Aeduellidae. Scale bars $5 \mathrm{~mm}$. a: isolated left maxilla in lateral view, locality Otovice "Chmelnice", P 64678; b: the skull in lateral view, locality Otovice "Stěnava", G 58; c, d: drawing and photograph of the skull roof in dorsal view, locality Otovice, NM-M 4910. Abbreviations: Dpt - dermopterotic, Dsph - dermosphenotic, Ext - extrascapular, Fr - frontal, Io - infraorbital, ioc - infraorbital canal, Md - mandible, mp - medial pit line, Mx - maxilla, Na - nasal, Op - operculum, Pa - parietal, pp - posterior pit line, soc - supraorbital canal, stc - supratemporal canal.

the dermopterotic. The supraorbital sensory canal continues diagonally across the dermopterotic towards the infraorbital sensory canal. The infraorbital sensory canal is traceable along the lateral edge of the dermopterotic and it traverses to the dermosphenotic in an anterior direction. The pores in a transverse orientation on the extrascapulars indicate the course of the occipital sensory canal connecting the sensory canals of the right and left sides of the skull. Right and left parietals carry middle and posterior pit lines, and their courses on the two parietals are not identical, the middle pit line is directed anterolaterally on the right parietal. The pit lines on the parietals are not found in the posterolateral region of the parietals as in Paramblypterus, but are shifted more medially.

Jaws (Text-fig. 15a). The maxilla (G 58, P 64678, NM-M 4930) has a typical aeduellid shape with a triangular shaped posterior part and narrow but strong anterior suborbital part. The maxilla is slightly bent and anterior part of the maxilla slightly rises upwards. The length of the maxilla is twice its depth in the posterior part. A strip of tubules from tubular teeth forms the ventral edge of the maxilla. The length of the maxilla on specimen P 64678 is $19 \mathrm{~mm}$ and the length of the tubules of the tubular teeth is $1 \mathrm{~mm}$, they are terminated by a $0.2 \mathrm{~mm}$ long acrodine tip. The tubules of the tubular teeth are covered with a thin lateral lamella similarly as in other Aeduellidae (Štamberg 2020).

Opercular apparatus (Text-fig. 16). The operculum is conspicuously elongated in a dorsoventral direction (NM-M 4910, P 64662). The dorsal third of the operculum bends anteriorly at an angle of $30^{\circ}$ (angle of bend formed by anterior margins of the dorsal and ventral branches of the operculum). The high operculum is narrowed at the dorsal end, the largest anteroposterior dimension is located along the ventral edge of the bone.

The suboperculum on P 30948 is trapezoidal in shape. The dorsal edge of the suboperculum slopes significantly anteriorly and therefore the posterior margin of the suboperculum is twice deeper than the anterior margin. The ventral border of the bone is slightly convex. The sculpture on the ventral region of the outer surface consists of two rows of long ridges parallel with the ventral edge of the bone. The long ridges become several short ridges and tubercles in a dorsal direction. 


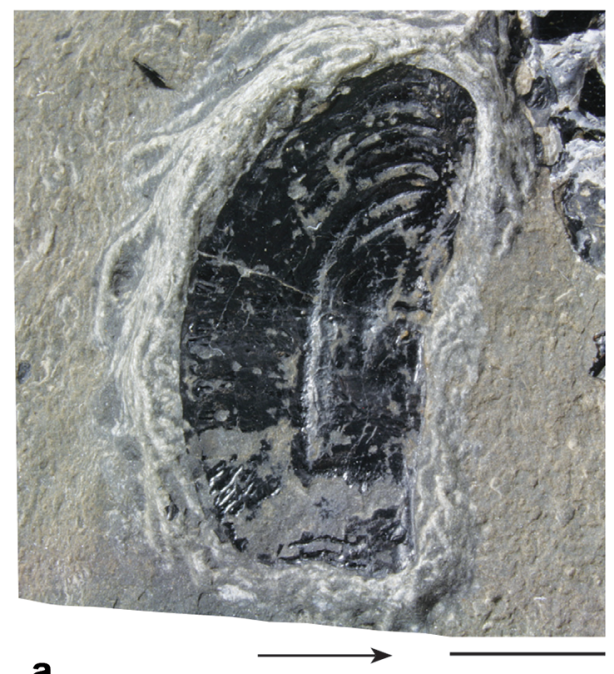

a

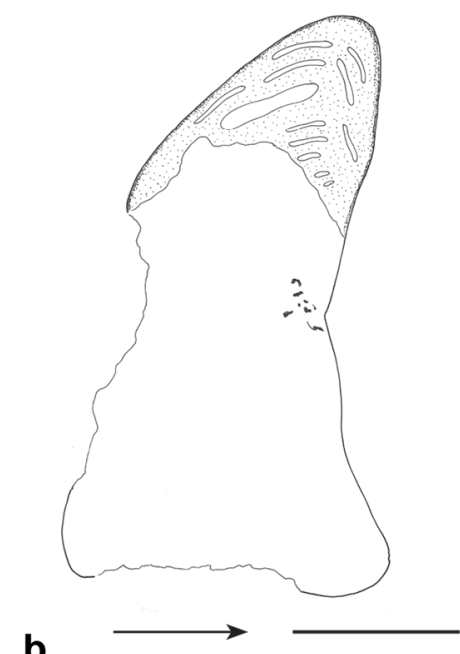

b

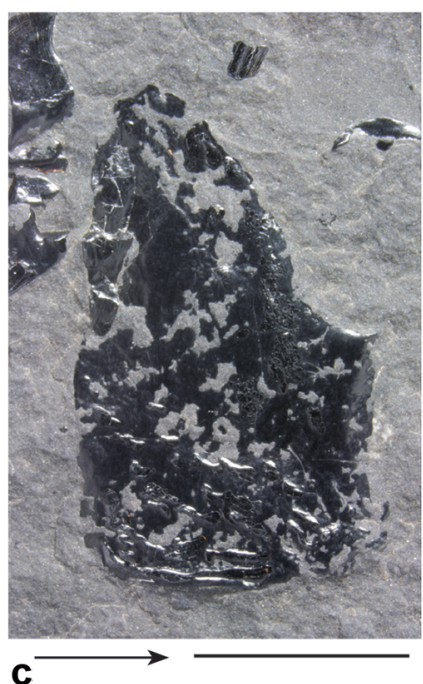

Text-fig. 16. Aeduellidae. Scale bars $5 \mathrm{~mm}$. Arrows indicate directio cranialis. a: right operculum in lateral view, locality Otovice “Chmelnice", P 64662; b: right operculum in lateral view, locality Otovice "Stěnava", NM-M 4910; c: right suboperculum in lateral view, locality Otovice "Chmelnice”, P 30948.

Body and squamation (Text-figs 14, 17). The whole specimen, DP 4307, with arched back measures $16 \mathrm{~cm}$ of the total body length, but the fragments of bodies with squamation (P 64662, NM-M 4912) suggest body remains certainly reaching $20 \mathrm{~cm}$ out of the total body length. The specimens from the Otovice limestone are usually significantly deformed. The shape of the body and corresponding ratio of the length and depth of the body were calculated for specimen DP 4307. The ratio of the total body length to its depth is 3.5 and ratio of the total body length to the length of the skull is about 5 .

The pelvic fin is situated midway between the skull and anal fin. The base of the fin extends over 4 scale rows and consists of 15 lepidotrichia. Minute scales with serrations on their posterior margin occur along the posterior part of the pelvic fin base (DP 4307). The anterior border of the fin is protected by the terminal pointed segments of 4 anterior lepidotrichia in combination with several fringing fulcra.

The anal fin base extends over 7 scale rows and a row of small denticulated scales were observed along the anal fin base in some specimens (P 80169, DP 4307). The anal fin consists of 24 lepidotrichia, of which the first five reaches the anterior border of the fin and their terminal segments form protection of the anterior edge of the fin.

The dorsal fin base extends over 7 scale rows (P 80169), it begins in the middle of the total body length, and its whole base is vertically just in front of the start of the anal fin base. Three large stout ridge scales precede the dorsal fin and a relatively large field of minute scales is located along the dorsal fin base (P 80169).

The caudal peduncle is strong (DP 4307, P 64650). The dorsal and ventral lobes of the caudal fins together form an angle of $53^{\circ}$, the dorsal lobe forms an angle of $23^{\circ}-24^{\circ}$ with the horizontal plane, and the ventral lobe forms an angle of $30^{\circ}$ (DP 4307, P 64650) with the horizontal plane. The dorsal lobe is twice the length of the ventral lobe. The ventral lobe consists of 14 segmented lepidotrichia and more than 60 segmented lepidotrichia constitute the dorsal lobe (P 64650). Segments of the lepidotrichia of all fins are very strong and short with sigmoid contact edges. The segments divide longitudinally dichotomously from the basal segment. The leading edges of the paired and unpaired fins are protected by the pointed terminal segments of the lepidotrichia in combination with fringing fulcra. The number of fringing fulcra on the anterior edge of the fins increases with age of the individual. From the short and strong segments of lepidotrichia it is possible to deduce that specimens of total body length $15 \mathrm{~cm}$ were adult.

The scales on the lateral side of the body are of oblong shape, also large and deep. They overlap one another by onefifth in an anteroposterior direction. The scales bearing pores of the lateral sensory line are slightly smaller than the scales located below the lateral sensory line. The deepest scales are in the anterior region of the body in two rows under the lateral sensory line. The individual of total body length $16 \mathrm{~cm}$ has scales in the region between the pelvic and anal fins in the row immediately below the lateral sensory line of depth 4-4.2 mm. Paramblypterus rohani or Bourbonnella hirsuta with the same total body length have scales half the depth in the same area. Peg and socket articulation is well developed. On the surface there is a combination of fine ridges along the posterior and ventral edges of the scale (P 80168, P 64892, P 64662) which protrude into the fine serration on the posterior margin of the scales and also as pointed tubercles on the posterior surface of the scales. Serration on the posterior edge of the scales and tubercles on the surface of the scale protrude into the fine spines (P 80179, DP 4307; Text-fig. 17a, b), the posterior area of the scale was extremely thorny. Fine spines are well developed along the entire posterior edge of the scales in the anterior region of the body (NM-M 4912, NM-M 4914), and they cover two thirds of the posterior edge of the scales in the region between the pelvic and anal fins. Fine spines border the posterior edge of the flank scales dorsally from the anal fin base (P 64650, P 80169). Irregularity in the squamation can be observed in specimen NM-M 4912 which exhibits scales twice the height as the surrounding ones, which is repeated in several rows (Text-fig. 17c, d). Large scales are 


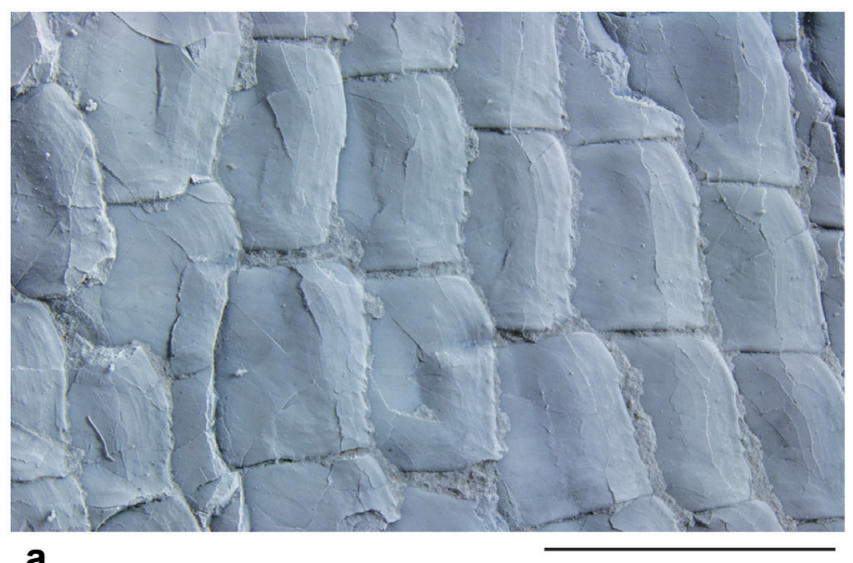

a

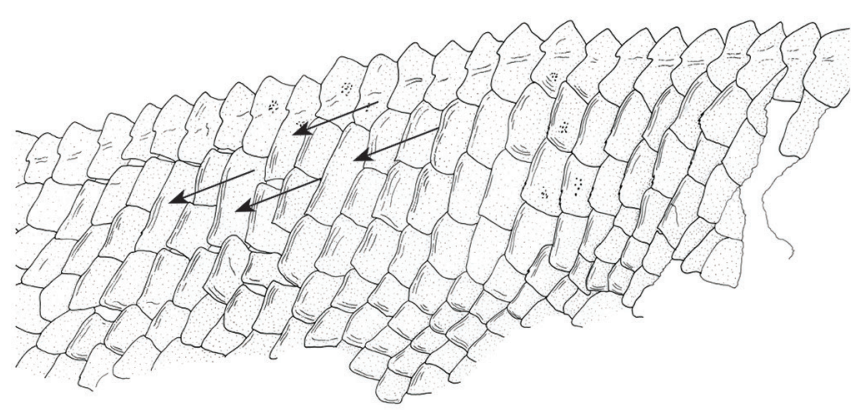

C

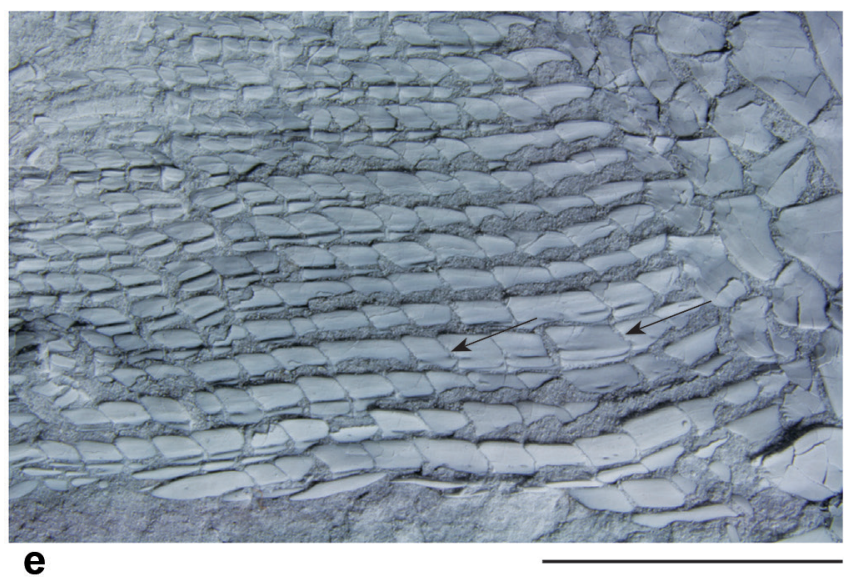

e

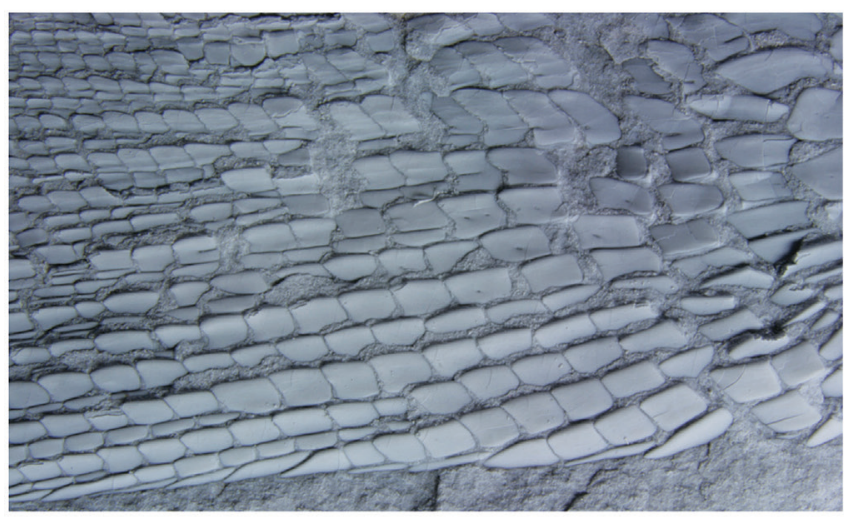

g
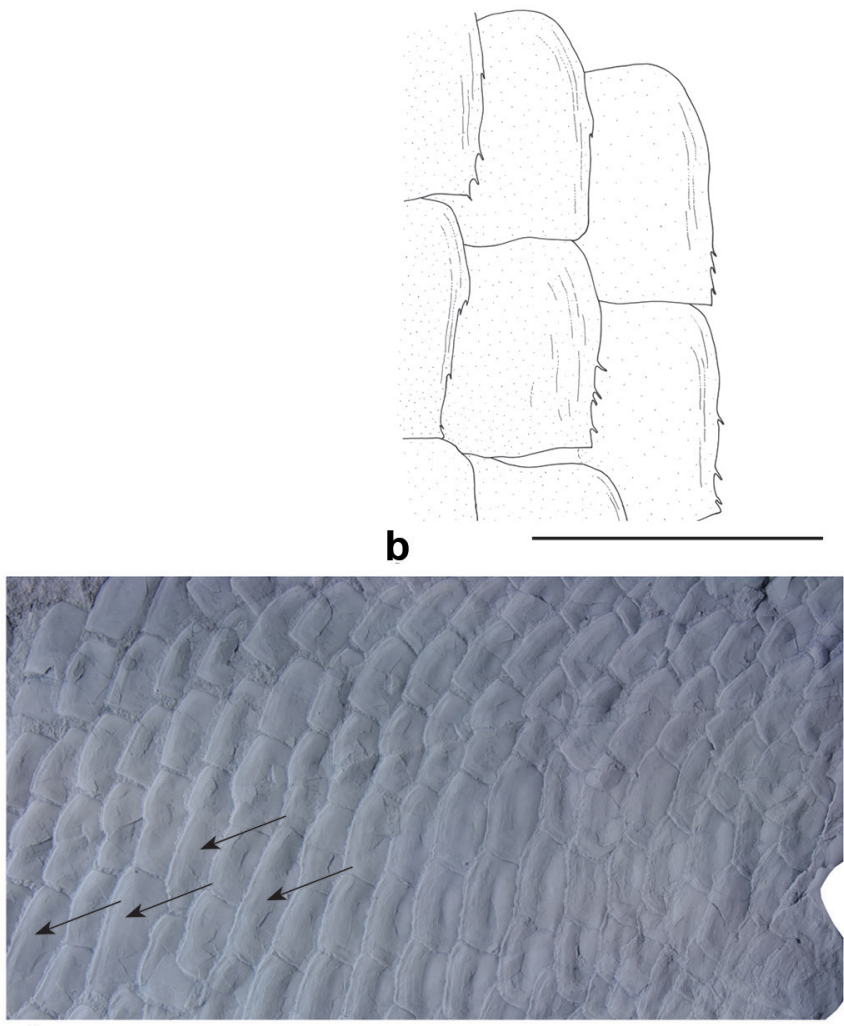

d

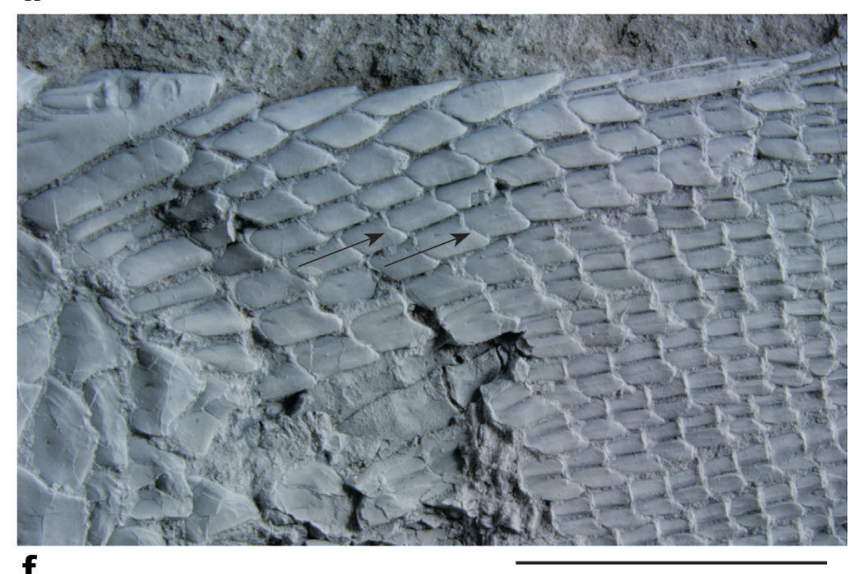

f

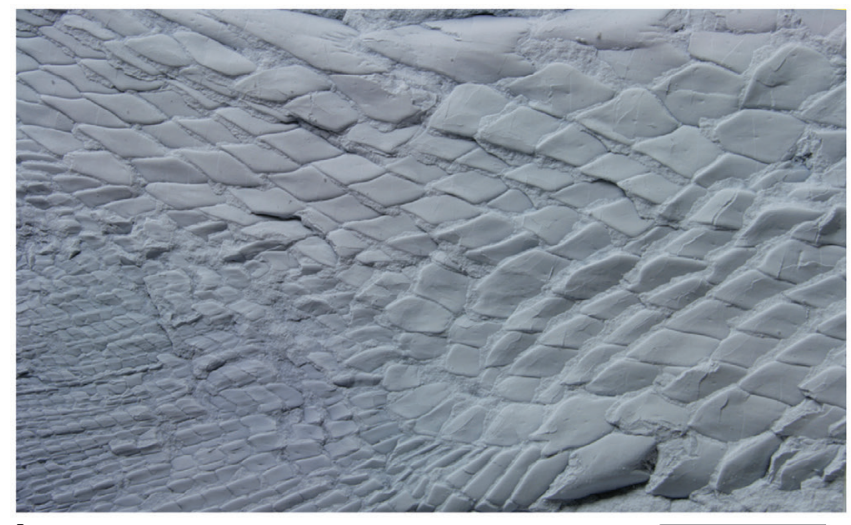

h

Text-fig. 17. Aeduellidae. Scale bars $5 \mathrm{~mm}$. a: the scales of oblong shape on the lateral side of the body, locality Otovice "Stěnava", DP 4307, whitened; b: drawing of the scales with fine denticles on their posterior edge, locality Otovice "Stěnava", DP 4307; c, d: drawing and photograph (whitened) of the scales of lateral side of the body, two times large scales occur in the rows 14, 16, 17, 19 (they are marked with arrows), locality Otovice "Černý potok", NM-M 4912; e: lepidotrichia of the anal fin with sigmoidal sutures between the segments (marked by arrows), locality Otovice, NM-M 4931, whitened; f: anterior edge of the dorsal fin and lepidotrichia with sigmoidal sutures between the segments, locality Otovice "Stěnava", DP 4307, whitened; g: anterior edge of the ventral lobe of the caudal fin, locality Otovice, NM-M 4931, whitened; h: the caudal peduncle with begin of bifurcation of the dorsal and ventral lobes of the caudal fin, locality Otovice, NM-M 4931. 
preserved in the $14^{\text {th }}, 16^{\text {th }}, 17^{\text {th }}$ and $19^{\text {th }}$ rows. These large scales are always twice the size as the scales in the row in front of them. They are always joined without any sutures. It is clear that these scales grew independently when the individual was in the juvenile stage and did not coalesce until a later stage of growth.

There are 6 scales above the lateral line in a row of scales in front of the anal fin and 9 scales below the lateral line. The scale count of specimen DP 4307 is

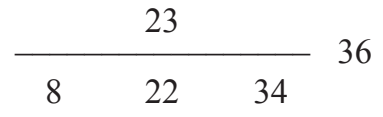

Specimen NM-M 4931 (Text-fig. 14b) demonstrates obvious differences as regards body shape and scale count. The body, including squamation and fins, is well preserved; on the contrary, the bones of the head are completely missing. The specimen has a slender body, $18 \mathrm{~cm}$ of the total body length. The ratio of the total body length to its depth is 4.6. The morphology of the fins and scales, including a serration which forms fine spines on the posterior edge of the scales, is the same as in the aeduellid describe above. The lateral side of the body, similarly as in NM-M 1912, bears scales twice the size of the neighbouring scales. They occur in the fourteenth and twentieth rows just below the lateral sensory line. The dorsal fin is moved slightly anteriorly relative to the above described specimen DP 4307 (Text-fig. 14a). The dorsal fin begins before the middle of the total body length and has the entire the level anteriorly to the anal fin base. The forward displacement of the dorsal fin may be caused by slight deformation of the specimen during fossilization since the inclination of the scale row in front of the anal fin is $50^{\circ}$, whereas in the previously described specimen, DP 4307, the scale rows are more upright and their inclination is $65^{\circ}$. Also the caudal peduncle is longer than in DP 4307. The dorsal lobe of the caudal fin forms an angle of $24^{\circ}$ with the horizontal plane, the ventral lobe of the caudal fin makes an angle of $15^{\circ}$ with the horizontal plane. The scale count can be determined unambiguously. It is

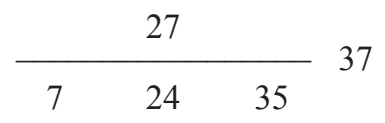

and shows a slight difference compared to the previous one. It is not yet possible to decide whether the different features found so far are a manifestation of species differences or only differences caused during the fossilization processes.

\section{Remarks and relationship to Aeduellidae}

Newly discovered specimens from the Otovice limestone in the Intra-Sudetic Basin are ranged to the family Aeduellidae. The studied specimens are incomplete, but unquestionable characters of the family Aeduellidae are present. They are very similar to Aeduella blainvillei in the sense of Heyler (1969), Poplin and Dutheil (2005) and Stamberg (2018) with respect to the following characters: The shape of the body, the body length/depth ratio is about 3.5 (after specimen DP 4307); the suboperculum very deep, with trapezoidal form with posterior edge twice longer than the anterior edge. Dorsal edge of the suboperculum conspicuously slopes and is curved; wide frontal which is only 1.6 times longer than it is wide; large dermosphenotic with prominent posterolateral process; identical position and size of the pelvic fin and unpaired fins; very deep scales on the lateral side of the body; the scale count close.

However, there are a number of features that distinguish the described fossils from Aeduella blainvillei: The parietal is not distinctly narrower than the frontal; the maxilla is robust, deeper posteriorly than in Aeduella blainvillei. The length of the maxilla is twice its depth in the posterior part; the operculum is very elongated in a dorsoventral direction with the dorsal third of the bone bent in an anterior direction, but there is no hump on the posterodorsal margin of the bone; only one pair of extrascapulars border the posterior edge of right and left parietals, unlike in Aeduella blainvillei which has numerous extrascapulars (Heyler 1969: figs $44,46)$; usually the serrations on the posterior edge of the scales protrude as fine spines and similarly-fine tubercles on the posterior region of the outer surface of the scales also protrude as fine spines. Serrations were observed on the posterior margin of scales in Aeduella blainvillei (Heyler 1969, Štamberg 2018), but these serrations did not protrude as into fine spines.

Some characters in the described specimens are similar to Bourbonnella, especially to Bourbonnella hirsuta ŠTAMBERG, 2007 from the Boskovice Basin. The following important features should be mentioned: the shape of the maxilla with length/depth ratio of 2; shape of the operculum; the scales with fine spines on their posterior edge.

On the contrary, the shape of the suboperculum, very deep scales on the lateral side of the body and the scale count clearly separate specimens from the Otovice Limestone from Bourbonnella hirsuta and whole genus Bourbonnella (Heyler 1969, Poplin 2001, Poplin and Dutheil 2005, Stamberg 2007). It is obvious that the studied specimens from the Otovice Limestone belong to a new genus of Aeduellidae which possess a mix of features characterizing the genera Aeduella and Bourbonnella. Numerous sets of individuals with the same characters have recently been found in the Prosečné Formation in the neighbouring Krkonoše Piedmont Basin (Štamberg 2002, 2013). For this reason, the material from the Otovice Limestone of the IntraSudetic Basin, which will form the basis for a new genus, will subsequently be comprehensively processed together with a set of specimens from the Prosečné Formation of the Krkonoše Piedmont Basin.

\section{Discussion}

The Ruprechtice Limestone Horizon and the overlying Otovice Limestone Horizon of the Olivětín Member (Asselian) are not stratigraphically very distant from each other, but the actinopterygian fauna differs considerably. The lake sediments where the Ruprechtice Limestone was formed were exclusively inhabited by numerous Paramblypterus vratislaviensis. This species is rare in the Otovice Limestone and, in contrast, the most numerous is Paramblypterus cf. rohani and also relatively abundant are fishes of the family Aeduellidae. Differences in the 
occurrence of actinopterygians between these two horizons of limestone can be also observed in the different content of other vertebrate fauna. In the Otovice Limestone, in addition to actinopterygians, very rare fragments of xenacanthid sharks are also known (Zajíc 2004) and amphibians are completely absent. A diverse fauna however can be seen in the Ruprechtice Limestone, which includes xenacanthid sharks Xenacanthus decheni (GoldFuss, 1847) and ?Xenacanthus oelbergensis (FrITSCH, 1890) (Schneider and Zajíc 1994); temnospondyl amphibians Onchiodon labyrinthicus GeINITZ, 1861; Melanerpeton pusillum Frič, 1878; Apateon umbrosa (FrITSCH, 1879); Cheliderpeton vranyi FRIČ, 1877 (Werneburg 1993, 1989) and seymouriamorph amphibians Discosauriscus pulcherrimus (FRITSCH, 1879) (Fritsch 1879, Werneburg and Kiersnowski 1996). Differences in the actinopterygian content and presence of other vertebrates in the Ruprechtice and Otovice limestones are probably a reflection of the different environmental conditions in which the limestones were deposited. Light grey and light pink Ruprechtice Limestone represent lake sediment deposited in a relatively shallow lake with a well-oxygenated bottom. In contrast, the Otovice Limestone represents anoxic deposits in a deeper closed lake (Tásler et al. 1979, Pešek 2004). Deposition of the Otovice Limestone took place in a slightly more humid climate (Prouza and Tásler 2001, Pešek 2004). The palaeogeographic conditions during the deposition of these two limestone horizons were also probably different, because they are separated from each other by the Upper Volcanic Horizon (Prouza and Tásler 2001, Pešek 2004). It is obvious, that volcanic activity certainly significantly changed the relief of the terrain, configuration of the river system and interconnections of the lakes.

It can be assumed that the deposition of the Otovice Limestone occurred under the same conditions as the deposition of the grey black claystone of the Rudník Horizon (Asselian) in the Krkonoše Piedmont Basin. Layers of grey black claystone of the Rudník Horizon with very common remains of Paramblypterus rohani are anoxic offshore deposits in a deep lake (Martínek et al. 2003). It can be assumed that the environment that prevailed at the time the Rudník Horizon was deposited was repeated a little later during the deposition of the Otovice Limestone. It was suitable environment for $P$. rohani and when the opportunity arose again to occupy a lake with similar conditions, $P$. rohani took advantage of it.

\section{Conclusions}

Revision and redescription of the actinopterygians from the Permian sediments of the Czech part of the Intra-Sudetic Basin are based as on both old material and on newly discovered specimens. Paramblypterus vratislaviensis is the main representative in the Ruprechtice Horizon and it also occurs rarely in the Otovice Limestone Horizon of the Olivětín Member. This fish of a small size, reaching usually $100-150 \mathrm{~mm}$ in total length is characterized by a short and high maxillary plate and narrow dermosphenotic. The distribution of Paramblypterus vratislaviensis is much greater than was shown by some findings from the Prosečné Formation in the neighbouring Krkonoše Piedmont Basin which has not yet been processed. Isolated occurrences of Paramblypterus zeidleri complement the list of species in the Ruprechtice Limestone Horizon.

Firstly, actinopterygians from the Otovice Limestone Horizon which are connected to the Otovice Limestone were described. Most of the specimens from the Otovice Limestone are similar to Paramblypterus rohani. They are very fragmentary and significantly affected by pressure during fossilization. The studied specimens did not provide the complete picture regarding these fossils, and are therefore referred to Paramblypterus cf. rohani. It is mainly the skull roof bones, upper jaw, morphology of the scales and the scale count which are the characters matching Paramblypterus rohani. One specimen of Paramblypterus sp. was kept separate as it differed from Paramblypterus cf. rohani in the less arched body and large dorsal and anal fins. Due to the complete absence of skull bones, no further comparison was possible and it is described separately so far.

A new set of actinopterygians belonging to Aeduellidae were described from the Otovice Limestone. Some of typical aeduellid features such as skull roof bones, maxilla, bones of the opercular apparatus, morphology of scales and scale count are similar to the genus Aeduella represented by Aeduella blainvillei, but some are similar to Bourbonnella, especially to Bourbonnella hirsuta. It is clear that it is a new genus that is close to both Aeduella and Bourbonnella. A complete description of this new genus will be completed after study of the numerous finds of aeduellids from sediments of the Kalná Horizon (Prosečné Formation) in the neighbouring Krkonoše Piedmont Basin.

The reasons for significantly different faunistic content in the stratigraphically close Ruprechtice Limestone Horizon and Otovice Limestone Horizon are discussed. Differences in the actinopterygian content and other vertebrates in the Ruprechtice and Otovice limestones can probably be related to the different environmental conditions in which the limestones were deposited. Volcanic activity recorded as the Upper Volcanic Horizon between the Ruprechtice Limestone Horizon and Otovice Limestone Horizon certainly significantly changed the relief of the terrain, configuration of the river system and interconnections of the lakes. The environment that prevailed during deposition of the Otovice Limestone was very similar to that during deposition of the Rudník Horizon of the Krkonoše Piedmont Basin, and therefore we encounter in the Otovice Limestone probably the same species, Paramblypterus rohani, as in the Rudník Horizon.

\section{Acknowledgements}

I am greatly obliged to Boris Ekrt (National Museum, Prague) and Martin Mazuch (Faculty of Science, Charles University, Prague) for access to the material in their care. I thank to Lauren Bapst (Muséum d'Histoire Naturelle, Neuchâtel) for providing photos of the type specimens published by Agassiz, to Miroslav Beneš (Museum of Eastern Bohemia in Hradec Králové) for the photos of some specimens, to Mrs Gill Horalek for correction of the English and to Jan Wagner (National Museum, Prague) for technical 
correction of the manuscript. I am thankful to reviewers Thomas Schindler and Jaroslav Zajíc for the careful reviews and constructive comments. This study is a part of the PolishCzech international research project Harmonia 2017/26/M/ ST10/00646 and Internal project of the Museum of Eastern Bohemia in Hradec Králové.

\section{References}

Agassiz, L. (1833): Recherches sur les Poissons fossiles. Aux frais de l'auteur, Neuchâtel, 336 pp. https://doi.org/10.5962/bhl.title.4275

Anonymous (1894): Braunauer Heimatkunde. - J. Swiral, Braunau, 244 pp.

Coates, M. I. (1993): New actinopterygian fish from the Namurian Manse Burn Formation of Bearsden, Scotland. Palaeontology, 36: 123-146.

Coates, M. I. (1998): Actinopterygians from the Namurian of Bearsden, Scotland, with comments on early actinopterygian neurocrania. - Zoological Journal of the Linnean Society, 122: 27-59. https://doi.org/10.1111/j.1096-3642.1998.tb02524.x

Dietze, K. (1999): Paramblypterus duvernoyi (Actinopterygii): Skull, morphology and intra-specific variation, and its implications for the systematics of paramblypterid fishes. - Journal of Vertebrate Paleontology, 19(2): 247-262.

https://doi.org/10.1080/02724634.1999.10011139

Dietze, K. (2000): A revision of paramblypterid and amblypterid actinopterygians from Upper CarboniferousLower Permian lacustrine deposits of Central Europe. Palaeontology, 43(5): 927-966. https://doi.org/10.1111/1475-4983.00156

Frič, A. (1877): Über einen neuen Saurier aus den Kalksteinen der Permformation (U. Dyas) aus Braunau in Böhmen. Verlag der königlich-böhmischen Gesellschaft der Wissenschaften, Prag, 3 pp.

Frič, A. (1878): O novém ještěru z permských vápencův u Broumova [About a new lizard from the limestone near Broumov]. - Vesmír, 7: 249-250. (in Czech)

Frič, A. (1912): Studien im Gebiete der Permformation Böhmens. - Archiv für die naturwissenschaftliche Landesdurchforschung Böhmens, 15(2): 1-52.

Fritsch, A. (1879): Fauna der Gaskohle und der Kalksteine der Permformation Böhmens. 1(1). - Selbstverlag (in Commission bei Fr. Řivnáč), Prag, 92 pp. https://doi.org/10.5962/bhl.title.14775

Fritsch, A. (1880): Fauna der Gaskohle und der Kalksteine der Permformation Böhmens. 1(2). - Selbstverlag (in Commission bei Fr. Řivnáč), Prag, pp. 93-126. https://doi.org/10.5962/bhl.title.14775

Fritsch, A. (1885): Fauna der Gaskohle und der Kalksteine der Permformation Böhmens. 2(1). - Selbstverlag (in Commission bei Fr. Řivnáč), Prag, 32 pp.

Fritsch, A. (1890): Fauna der Gaskohle und der Kalksteine der Permformation Böhmens. 3(1). - Selbstverlag (in Commission bei Fr. Řivnáč), Prag, 48 pp.

Fritsch, A. (1894): Fauna der Gaskohle und der Kalksteine der Permformation Böhmens. 3(3). - Selbstverlag (in Commission bei Fr. Řivnáč), Prag, pp. 81-104.
Fritsch, A. (1895): Fauna der Gaskohle und der Kalksteine der Permformation Böhmens. 3(4). - Selbstverlag (in Commission bei Fr. К̌ivnáč), Prag, pp. 105-132.

Fritsch, A. (1901): Fauna der Gaskohle und der Kalksteine der Permformation Böhmens. 4(3). - Selbstverlag (in Commission bei Fr. Řivnáč), Prag, pp. 63-101.

Gardiner, B. G. (1984): The relationships of the palaeoniscoid fishes, a review based on new specimens of Mimia and Moythomasia from the Upper Devonian of Western Australia. - Bulletin of British Museum (Natural History), Geology series, 3(4): 173-428.

Gardiner, B. G., Bartram (1977): The homologies of the ventral cranial fissures osteichthyans. - In: Andrews, S. M., Miles, R. S., Walker, A. D. (eds), Problems in vertebrate evolution, pp. 227-245. London.

Geinitz, H. B. (1860): Zur Fauna des Rotliegenden und Zechsteins. - Zeitschrift der Deutschen Geologischen Gesellschaft, 12(3): 467-470.

Geinitz, H. B. (1861): Dyas oder die Zechsteinformation und das Rothliegende, Vol. 1, Die Animalischen Ueberreste der Dyas. - Wilhelm Engelmann, Leipzig, 130 pp. https://doi.org/10.5962/bhl.title.44568

Giebel, C. G. (1848): Fauna der Vorwelt mit steter Berücksichtigung der lebenden Thiere. Erster Band: Wirbelthiere. Dritte Abtheilung: Fische. - F. A. Brockhaus, Leipzig, 467 pp. https://doi.org/10.5962/bhl.title.24938

Goldfuss, G. A. (1847): Beiträge zur vorweltlichen Fauna des Steinkohlengebirges. - Naturhistorischer Verein für die preussischen Rheinlande (in Commission bei Henry \& Cohen), Bonn, [4] + 26+ [2] pp. +5 pls.

Gottfried, M. D. (1993): A subadult "palaeoniscoid" (Actinopterygii, Osteichthyes) from the Upper Pennsylvanian of Kansas, U.S.A. - In: Heidtke, U. (ed.), New Research on Permo-Carboniferous Faunas. Pollichia-Buch, 29: 103-112.

Grande, L., Bemis, W. (1998): A comprehensive phylogenetic study of amiid fishes (Amiidae) based on comparative skeletal anatomy. An empirical search for interconnected patterns of natural history. - Memoir, Society of Vertebrate Paleontology, 4: 1-690. (Supplement to Journal of Vertebrate Paleontology, vol. 18, no. 1) https://doi.org/10.1080/02724634.1998.10011114

Havlena, V., Špinar, Z. (1956): Stratigraficko-paleontologické výzkumy v okolí Semil, Vrchlabí, Trutnova a Broumova [Stratigraphic and paleontological research in the vicinity of Semily, Vrchlabí, Trutnov and Broumov]. Zprávy o geologických výzkumech v roce 1955: 60-61. (in Czech)

Heckel, W. J., Kner, R. (1861): Neue Beiträge zur Kenntniss der fossilen Fische Österreichs. - Denkschriften der Kaiserlichen Akademie der Wissenschaften, Mathematischnaturwissenschaftlichen Classe, 19: 49-63.

Heyler, D. (1969): Vertébrés de l'Autunien de France (Series Cahiers de Paléontologie). - Editions du Centre national de la recherche scientifique, Paris, 312 pp.

Heyler, D. (1971): Sur des os de Paramblypterus du gisement de Surmoulin. - Bulletin de la Société d'Histoire Naturelle d'Autun, 57: 3-14.

Martínek, K., Blecha, M., Daněk, V., Franců, J., Hladíková, J., Johnová, R., Uličný, D. (2006): Record of palaeo- 
environmental changes in a Lower Permian organic-rich lacustrine succession: Integrated sedimentological and geochemical study of the Rudník member, Krkonoše Piedmont Basin, Czech Republic. - Palaeogeography, Palaeoclimatology, Palaeoecology, 230: 85-128. https://doi.org/10.1016/j.palaeo.2005.07.009

Opluštil, S., Schmitz, M., Kachlík, V., Štamberg, S. (2016): Re-assessment of lithostrastigraphy, biostratigraphy, and volcanic activity of the Late Paleozoic Intra-Sudetic, Krkonoše-Piedmont and Mnichovo Hradiště basins (Czech Republic) based on new U-Pb CA-ID-TIMS ages. - Bulletin of Geosciences, 91(2): 399-432. https://doi.org/10.3140/bull.geosci.1603

Pešek, J. (2004): Late Paleozoic limnic basins and coal deposits of the Czech Republic. - Folia Musei Rerum Naturalium Bohemiae Occidentalis, Geologica, Editio specialis 1, Plzeň, $188 \mathrm{pp}$.

Poplin, C. (2001): Le genre Bourbonnella (Actinopterygii, Aeduellidae): révision et description d'une nouvelle espèce du Stéphanien (Carbonifère supérieur) de Montceau-les-Mines (Massif Central, France). - Annales Paléontologie, 87(4): 231-248. https://doi.org/10.1016/S0753-3969(01)80012-4

Poplin, C., Dutheil, D. B. (2005): Les Aeduellidae (Pisces, Actinopterygii) carbonifères et permiens: systématique et étude phylogénétique préliminaire. - Geodiversitas, 27(1): 17-33.

Prouza, V., Tásler, R. (2001): Podkrkonošská pánev [Krkonoše Piedmont Basin]. - In: Pešek, J. et al., Geologie a ložiska svrchnopaleozoických limnických pánví České republiky [Geology and deposits of Late Paleozoic limnic basins of the Czech Republic]. Český geologický ústav, Praha, pp. 128-166. (in Czech)

Romer, A. S. (1945): Vertebrate paleontology. - University of Chicago Press, Chicago, 687 pp.

Sauvage, H. E. (1888): Poissons du terrain Houiller de Commentry. - In: Études sur le terrain Houiller de Commentry, Livre 3 - Faunes ichthyologique et entomologique, pt. 1. Societé de l'Industrie Minérale, St-Etienne, pp. 39-120.

Schindler, T. (1993): “Elonichthys" palatinus n. sp., a new species of actinopterygians from the Lower Permian of the Saar-Nahe Basin (SW-Germany). - In: Heidtke, U. (ed.), New Research on Permo-Carboniferous Faunas. Pollichia-Buch, 29: 67-81.

Schindler, T. (2007): Knochenfische (Osteichthyes) - Die häufigsten Wirbeltiere permokarbonischer Seen. - In: Schindlet, T., Heidtke, U. H. J. (eds), Kohlensümpfe, Seen und Halbwüsten. Pollichia, Sonderveröffentlichung, 10: 240-256.

Schneider, J. W., Lucas, S. G., Scholze, F., Voigt, S., Marchetti, L., Klein, H., Opluštil, S., Werneburg, R., Golubev, V. K., Barrick, J. E., Nemyrovska, T., Ronchi, A., Day, M. O., Silantiev, V. V., Rößler, R., Saber, H., Linnemann, U., Zarinova, V., Shen, S.-Z. (2020): Late Paleozoic-early Mesozoic continental biostratigraphy - Links to the Standard Global Chronostratigraphic Scale. - Palaeoworld, 29(2): 186-238.

https://doi.org/10.1016/j.palwor.2019.09.001

Schneider, J., Werneburg, R. (2012): Biostratigraphie des Rotliegend mit Insekten und Amphibien. - In: Deu- tsche Stratigraphische Kommission (ed.), Stratigraphie von Deutschland X. Rotliegend. Teil I: Innervariscische Becken. Schriftenreihe der Deutschen Gesellschaft für Geowissenschaften, 61: 110-142.

https://doi.org/10.1127/sdgg/61/2012/110

Schneider, J., Zajíc, J. (1994): Xenacanthiden (Pisces, Chondrichthyes) des mitteleuropäischen Oberkarbon und Perm - Revision der Originale zu Goldfuss 1847, Beyrich 1848, Kner 1867 und Fritsch 1879-1890. - Freiberger Forschungshefte, C, 452: 101-151.

Schultze, H.-P. (2008): Nomenclature and homologization of cranial bones in actinopterygians. - In: Arratia, G., Schultze, H.-P., Wilson, M. V. H. (eds), Mesozoic Fishes 4 - Homology and Phylogeny. Verlag Dr. Friedrich Pfeil, München, pp. 23-49.

Štamberg, S. (1976): Revision of genus Paramblypterus (Actimopterygii) from the Lower Permian of Bohemia. - Sborník geologických věd, Paleontologie, 18: 9-52.

Štamberg, S. (1999): Paleontologické lokality permu olivětínských vrstev vnitrosudetské pánve a přehled fauny [Palaeontological localities of the Permian Olivětín Member (Intrasudetic Basin) and the fauna summary]. - Acta Musei reginaehradecensis, Series A: Scientiae naturales, 27(1999): 3-18. (in Czech with English Abstract)

Stamberg, S. (2002): Actinopterygian fishes from the new Lower Permian locality of the Krkonoše Piedmont Basin. - Journal of the Czech Geological Society, 47(3-4): $147-154$.

Štamberg, S. (2006): Carboniferous/Permian actinopterygian fishes of the continental Basins of the Bohemian Massif, Czech Republic - an overview. - In: Lucas, S., Cassinis, G., Schneider, J. W. (eds), Non-Marine Permian Biostratigraphy and Biochronology. Special Publications, Geological Society, London, 265: 217-230. https://doi.org/10.1144/GSL.SP.2006.265.01.10

Štamberg, S. (2007): Permo-Carboniferous Actinopterygians of the Boskovice Graben. Part 1. Neslovicella, Bourbonnella, Letovichthys, Elonichthys. - Museum of Eastern Bohemia, Hradec Králové, 155 pp.

Stamberg, S. (2013): New data on the osteology of the actinopterygian fish Amblypterus and the relations of Amblypterus to Paramblypterus. - Acta Musei Nationalis Pragae, Series B - Historia Naturalis, 69(3-4): 183-193. https://doi.org/10.14446/AMNP.2013.183

Štamberg, S. (2018): Actinopterygians of the Permian locality Buxières-les-Mines (Bourbon-l'Archambault Basin, France) and their relationship to other early actinopterygians. - Fossil Imprint, 74(3-4): 245-291. https://doi.org/10.2478/if-2018-0017

Štamberg, S. (2020): Teeth of actinopterygians from the Permo-Carboniferous of the Bohemian Massif with special reference to the teeth of aeduellidae and Amblypteridae. - Bulletin of Geosciences 95(4): 369-389. https://doi.org/10.3140/bull.geosci.1799

Štamberg, S., Zajíc, J. (2008): Carboniferous and Permian faunas and their occurrence in the limnic basins of the Czech Republic. - Museum of Eastern Bohemia, Hradec Králové, 224 pp.

Tásler, R. et al. (1979): Geologie české části vnitrosudetské pánve [Geology of the Czech part of the Intra-Sudetic 
Basin]. - Ústřední ústav geologický, Praha, 292 pp. (in Czech)

Traquair, R. H. (1877): On the Agassizian genera Amblypterus, Palaeoniscus, Gyrolepis and Pygopterus. - Quarterly Journal of the Geological Society, 33: 548-578. https://doi.org/10.1144/GSL.JGS.1877.033.01-04.33

Weiss, E. (1864): Leitfische des Rotliegenden in den Lebacher und äquivalenten Schichten des Saarbrückisch-pfälzischen Kohlengebirges. - Zeitschrift der Deutschen geologischen Gesellschaft, 16: 272-302.

Werneburg, R. (1989): Labyrinthodontier (Amphibia) aus dem Oberkarbon und Unterperm Mitteleuropas - Systematik, Phylogenie und Biostratigraphie. - Freiberger Forschungshefte, C, 436: 7-57.

Werneburg, R. (1993): Onchiodon (Eryopidae, Amphibia) aus dem Rotliegend des Innersudetischen Beckens (Böhmen). - Paläontologische Zeitschrift, 67(3-4): 343-353. https://doi.org/10.1007/BF02990287

Werneburg, R., Kiersnowski, H. (1996): A discosauriscid amphibian from the Rotliegend of the Intrasudetic Basin in Poland and its biostratigraphic importance. - Acta
Universitatis Wratislaviensis, Prace Geologiczno-Mineralogiczne, 52: 117-125.

Werneburg, R., Schneider, J. W. (2006): Amphibian biostratigraphy of the European Permo-Carboniferous. In: Lucas, S. G., Cassinis, G., Schneider, J. W. (eds), Non-marine Permian Biostratigraphy and Biochronology. Special Publications, Geological Society, London, 265: 201-215.

https://doi.org/10.1144/GSL.SP.2006.265.01.09

Werneburg, R., Steyer, J. S. (2002): Revision of Cheliderpeton vranyi Fritsch, 1877 (Amphibia, Temnospondyli) from the Lower Permian of Bohemia (Czech Republic). - Paläontologische Zeitschrift, 76(1): 142-162. https://doi.org/10.1007/BF02988193

Woodward, A. S. (1891): Catalogue of the Fossil Fishes in the British Museum (Natural History) London, 2. - British Museum (Natural History), London, 567 pp. https://doi.org/10.5962/bhl.title.162355

Zajíc, J. (2004): Vertebrate biozonation of the Permo-Carboniferous lakes of the Czech Republic - new data. - Acta Musei reginaehradecensis, Series A: Scientiae naturales, 30: $16-17$. 